Andrews University

Digital Commons @ Andrews University

2000

\title{
A Church-Growth Strategy for Revitalizing the Kolhapur Church
}

Bhupal R. Chandanshive

Andrews University

Follow this and additional works at: https://digitalcommons.andrews.edu/dmin

Part of the Practical Theology Commons

\section{Recommended Citation}

Chandanshive, Bhupal R., "A Church-Growth Strategy for Revitalizing the Kolhapur Church" (2000).

Professional Dissertations DMin. 457.

https://dx.doi.org/10.32597/dmin/457

https://digitalcommons.andrews.edu/dmin/457

This Project Report is brought to you for free and open access by the Graduate Research at Digital Commons @ Andrews University. It has been accepted for inclusion in Professional Dissertations DMin by an authorized administrator of Digital Commons @ Andrews University. For more information, please contact repository@andrews.edu. 


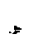 \\ ABSTRACT \\ A CHURCH-GROWTH STRATEGY FOR REVITALIZING \\ THE KOLHAPUR CHURCH}

\section{by}

Bhupal R. Chandanshive

Adviser: Werner K. Vyhmeister 


\title{
ABSTRACT OF GRADUATE STUDENT RESEARCH
}

Dissertation

\author{
Andrews University \\ Seventh-day Adventist Theological Seminary
}

Title: A CHURCH-GROWTH STRATEGY FOR REVITALIZING THE KOLHAPUR CHURCH

Name of researcher: Bhupal $R$. Chandanshive

Name and degree of adviser: Werner K. Vyhmeister, Ph.D.

Date completed: September 2000

The task of this dissertation was to study the factors that have affected the growth of the Kolhapur church in south Maharashtra and to develop a strategy to revitalize the church. Twenty-five years ago, Seventh-day Adventist churches in Maharashtra were spiritually lively and active. But in recent years the churches have become weak; the attendance is nominal and there is little vibrancy.

The Seventh-day Adventist Church in Kolhapur was viewed through the dynamics of church-growth principles, especially those applicable in the Indian context. The history of the church, together with membership statistics, provided 
information on the church over the last decade. The opinions of present and former members, as well as former pastors, were consulted to obtain information on the church and factors affecting its growth. For the sake of comparison, three growing churches in Maharashtra were studied.

Based on church-growth theory and the analysis of the Kolhapur Church, a growth strategy was devised. This strategy places emphasis on revival, accompanied by improvements in the worship services and preaching. It suggests celebrations and conventions as appropriate means to attain both qualitative and quantitative growth. The strategy also recommends the formation of small groups, a women's group, and house churches.

Following this strategy should help revitalize the church. It should also provide for qualitative and quantitative growth, with prepared lay persons leading out in worship and evangelism. The pastoral force will be encouraged and young people will be inspired to enter pastoral training. 
Andrews University

Seventh-day Adventist Theological Seminary

A CHURCH-GROWTH STRATEGY FOR REVITALIZING

THE KOLHAPUR CHURCH

\author{
A Dissertation \\ Presented in Partial Fulfillment \\ of the Requirements for the Degree \\ Doctor of Ministry
}

by

Bhupal R. Chandanshive

September 2000 



\title{
A CHURCH-GROWTH STRATEGY FOR
}

REVITALIZING THE KOLHAPUR

\author{
A dissertation \\ presented in partial fulfillment \\ of the requirements for the degree \\ Doctor of Ministry
}

by

Bhupal R. Chandanshive

APPROVAL BY THE COMMITTEE:

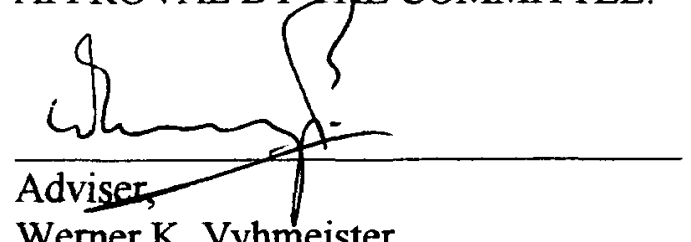

Werner K. Vyhmeister

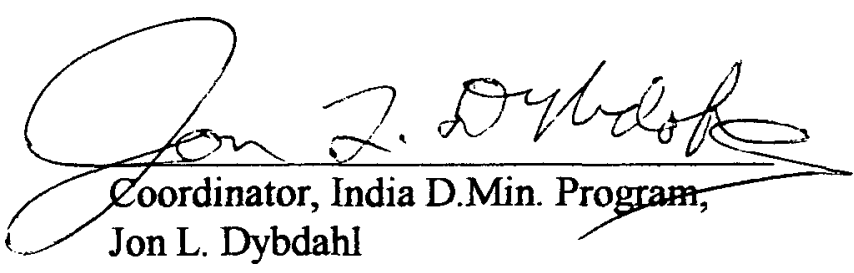

sar lif

Samuel J. Gaikwad

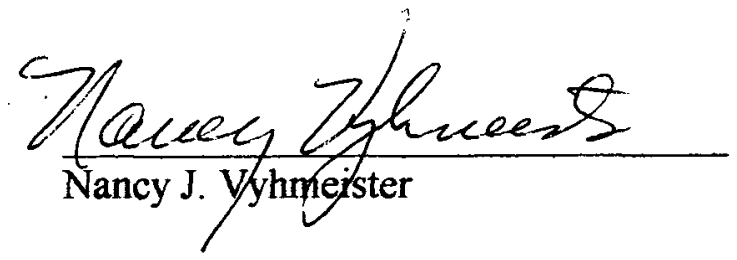

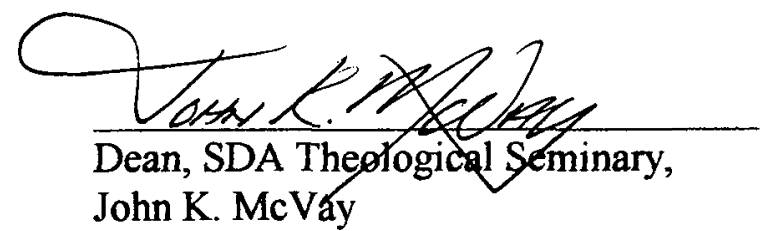

Sept.13,2000

Date approved 
In memory of

my dear father, the late Ramachandra Chandanshive, a humble, sincere, and very hard-working person 
TABLE OF CONTENTS

LIST OF TABLES $\ldots \ldots \ldots \ldots \ldots \ldots \ldots \ldots \ldots \ldots \ldots \ldots \ldots \ldots \ldots \ldots \ldots$

LIST OF ILLUSTRATIONS $\ldots \ldots \ldots \ldots \ldots \ldots \ldots \ldots \ldots \ldots \ldots \ldots \ldots$

ACKNOWLEDGMENTS $\ldots \ldots \ldots \ldots \ldots \ldots \ldots \ldots \ldots \ldots \ldots \ldots \ldots \ldots$

Chapter

1. INTRODUCTION $\ldots \ldots \ldots \ldots \ldots \ldots \ldots \ldots \ldots \ldots \ldots$

Purpose ....................... 1

Justification . . . . . . . . . . . . 1

Overview of the Dissertation $\ldots \ldots \ldots \ldots \ldots \ldots 3$

2. PRINCIPLES OF CHURCH GROWTH $\ldots \ldots \ldots \ldots \ldots \ldots \ldots$

Spiritual Principles $\ldots \ldots \ldots \ldots \ldots \ldots \ldots \ldots \ldots 5$

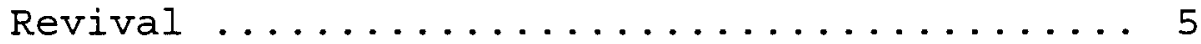

Organizational Preparation ......... 7

Spiritual Preparation ............. 7

Spiritual Life of the Church ........... 9

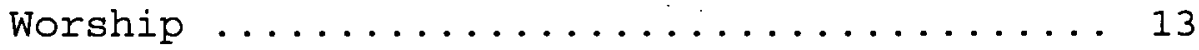

Discipleship of Members ............ 16

Strategic Principles ................ 19

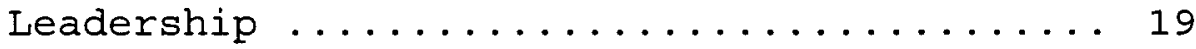

Pastoral Leadership .............. 20

Lay Leadership ................ 22

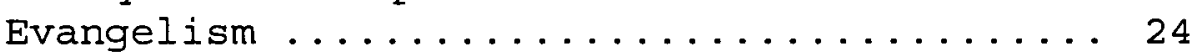

New Unit Principle ............... 28

People Movements ................. 31

Balancing Qualitative and Quantitative

Church Growth .................. 33

The Holy Spirit in Church Growth ........ 35

3. THREE MODEL GROWING CHURCHES $\ldots \ldots \ldots \ldots \ldots \ldots \ldots$

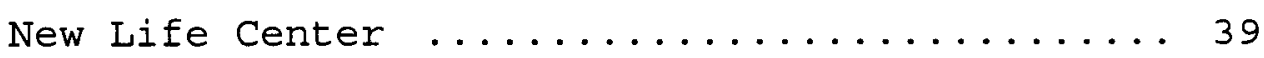

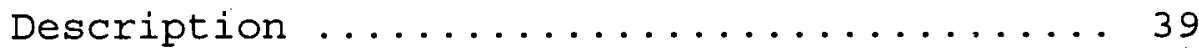

Evaluation ................... 42

Free Methodist Church ............... 44

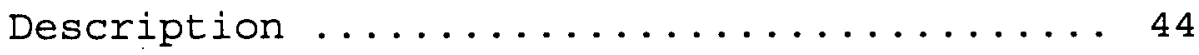




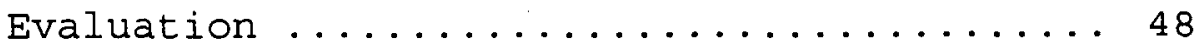

Bethel Savior's Alliance Church .......... 49

Description ................... 49

Evaluation .................. 53

4. THE KOLHAPUR CHURCH $\ldots \ldots \ldots \ldots \ldots \ldots \ldots \ldots \ldots \ldots$

The Setting of the Kolhapur Church ....... 55

General Information .............. 55

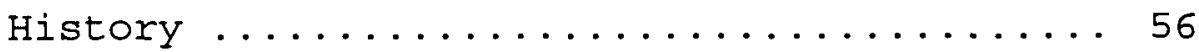

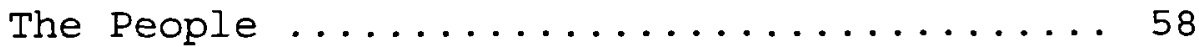

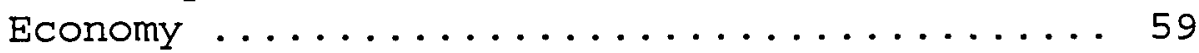

Education ...................6 60

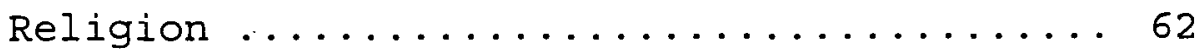

A Brief History of the Kolhapur Church ..... 63

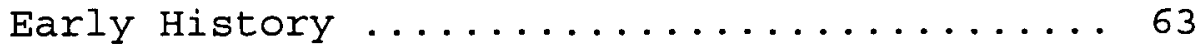

Pastors and Evangelistic Programs ........ 65

First Period ................. 66

Second Period ................ 67

Major Events in the Church ........... 70

The Surveys .................... 72

Active Members ................... 73

Spiritual Life ............... 75

Church Activities and Emphasis ...... 77

Inactive Members ............... 83

Former Pastors ................ 88

Church Growth at Kolhapur ........... 90

Church Records ................... 90

Analysis of Church Growth Patterns ....... 96

5. STRATEGY FOR REVITALIZING THE KOLHAPUR CHURCH ... 103

Programs and Celebrations ............ 104

Church Programs .................. 105

Church services .............. 105

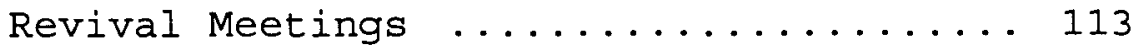

Lay Mela (Lay Congress) . .......... 115

Church Celebrations ............. 118

A Church Dedication Day ........... 118

General Christian Festivals ......... 119

National Festivals ............... 119

Discipling through Small Groups ......... 120

General Considerations . . . . . . . . . . 124

General Procedures ................. 125

Ice Breaking ................... 125

Praise Time .................. 126

Reflecting on a Bible Passage ....... 126 


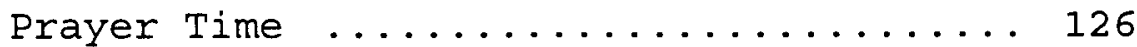

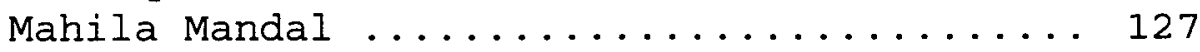

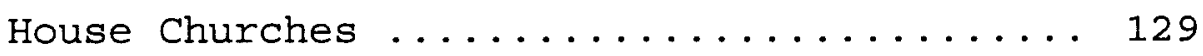

6. CONCLUSIONS AND RECOMMENDATIONS ........... 133

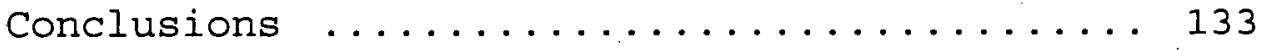

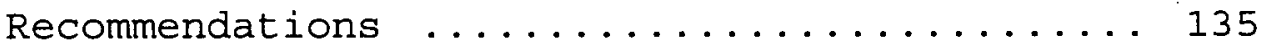

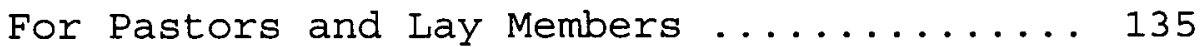

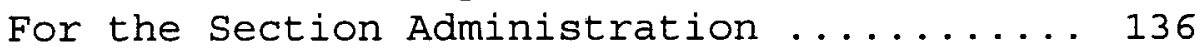

For Further study ................. 136

Appendix

A. QUESTIONNAIRE FOR MODEL CHURCHES ............................

B. SURVEYS ON THE KOLHAPUR CHURCH ........... 142

C. VARIOUS TYPES OF SMALL GROUPS $\ldots \ldots \ldots \ldots \ldots \ldots \ldots$

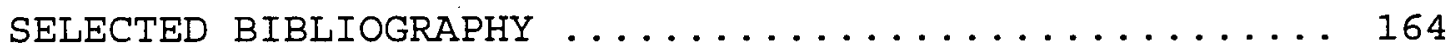

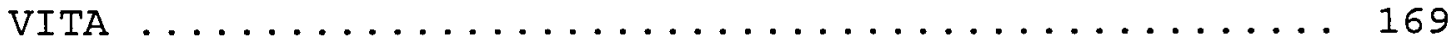




\section{LIST OF TABLES}

1. Age of Respondents .................... 74

2. Length of Membership in the Church .......... 74

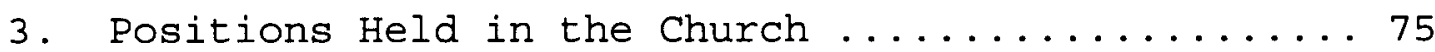

4. Spiritual Life and Involvement in

Church Activities ................. 76

5. Resources for strengthening Spiritual Life ..... 77

6. Engagement in Soul Winning $\ldots \ldots \ldots \ldots \ldots \ldots \ldots$

7. Church Emphasis ...................... 79

8. Fellowship in the Church ................ 79

9. The Pastor's Emphasis ................. 80

10. Section Administration Evaluation ........... 81

11. Age of Respondents .................. 83

12. Length of Membership in the Church ..........84

13. Resources for Strengthening Spiritual Life ..... 85

14. Reasons for Stopping Church Attendance ........ 86

15. Statistical Report of Kolhapur Church, 1992-1999 . 92

16. Church Membership, 1925-1999 ............. 95 


\section{LIST OF ILLUSTRATIONS}

1. Membership of Kolhapur Church, 1992-1999 ....... 93

2. Composite Membership of Kolhapur Church ........ 94

3. Membership Loss and Gain, 1992-1999 .......... 95 


\section{ACKNOWLEDGMENTS}

It is my pleasure to extend gratitude and appreciation to many individuals who have rendered their valuable time and effort and enabled me to complete this dissertation.

To Dr. Werner K. Vyhmeister, my adviser, I offer thanks for giving generously of his time, guidance, suggestions, and assistance and enabling me to complete the final work.

To Dr. Nancy Vyhmeister, I give thanks for her tireless correction, guidance, suggestions, and encouragement in completing this paper.

To Dr. Bruce Lee Bauer, my initial adviser, I extend my gratitude for his encouragement, guidance, assistance, and for contributing many excellent suggestions.

To Dr. Samuel M. Gaikawad, I extend my gratitude for reviewing this work, making suggestions, and assisting me.

To Mr. Bobby Waugh and Mr. Giri Charles, I express my heartfelt gratitude and thanks for their tireless work to type the initial manuscript.

To the Maharashtra Section and the Southern Asia 
Division, my sincere thanks for giving me the opportunity to complete my study for the Doctor of Ministry.

To my wife Shakuntala, for her constant encouragement in my studies and for assisting me in the completion of my paper, I extend my gratitude. My thanks go as well to my sons, Paul and Ketan, and daughter Snehal for their moral support and help extended during my busy study period.

To God, the eternal enduring source of all wisdom and strength, I thank Him for His guidance, protection, and for giving me good health and strength. 
CHAPTER 1

INTRODUCTION

Purpose

The purpose of this dissertation is to study the factors that have affected the growth of the Kolhapur Church in south Maharashtra and to develop practical ways to revitalize its growth.

\section{Justification}

Written reports from members suggest that twenty-five years ago the Seventh-day Adventist churches in

Maharashtra were spiritually lively and active. There was a great awakening and a high spirit among the laity. But in recent years the situation has been altogether different. The churches are weak, the attendance is low, and there is no vibrancy of spirit.

As part of the Seventh-day-Adventist (SDA) world church, the churches in Maharashtra have the responsibility to take part in the task of world evangelization. To achieve this task the churches must be 
awakened.

In recent times there appears to have been a great awakening and advancement among various religious groups and sects in Maharashtra. Pentecostal and Alliance groups seem to be spiritually alive and a good number of people have been drawn into their fellowship. But the SDA churches in the same locality seem nominal and stagnant.

The nominal condition of the churches in Maharashtra has affected the pastors. Due to the poor condition of the churches, the existing pastoral force is discouraged and many workers have almost given up the challenge of evangelism. There is unhappiness and restlessness among the pastors. Further, noticing the nominal condition of the churches and the pastors, in the last nine years hardly one Maharashtrian student has graduated from spicer Memorial College with a major in religion with the aim of entering the pastoral ministry.

The SDA church leadership in Maharashtra needs a model to follow to promote and enhance the growth of churches. The researcher has served almost all of the major churches in Maharashtra during an experience of sixteen years. He has been disturbed by the nominal conditions of the churches and is thus interested in 
offering some practical suggestions to enhance the growth of the churches.

\section{Overview of the Dissertation}

Chapter 1 introduces the dissertation while chapter 2 surveys the literature on church growth. For comparison, chapter 3 presents three growing churches. Chapter 4 describes the Kolhapur church and its growth patterns. Chapter 5 proposes a strategy to revitalize the Kolhapur church. The conclusions and recommendations appear in chapter 6 . 
CHAPTER 2

PRINCIPLES OF CHURCH GROWTH

Warren emphasizes five dimensions of church growth that lead to church health:

1. Churches grow warmer through fellowship.

2. Churches grow deeper through discipleship.

3. Churches grow stronger through worship.

4. Churches grow broader through ministry.

5. Churches grow larger through evangelism. ${ }^{1}$

In this chapter a summary of key church-growth principles is presented. The principles that have been chosen are ones that are generally accepted and applicable in the context of India, specifically for the field of Maharashtra. These principles are categorized as spiritual and strategic. Following them brings growth, both quantitative and qualitative. The importance of balancing these two categories of principles and the special place for the working of the Holy sprit in church growth are reviewed

\footnotetext{
'Rick Warren, The Purpose Driven Church (Grand Rapids: Zondervan, 1995), 49.
} 
to close the chapter.

\section{Spiritual Principles}

Churches exist to provide a favorable atmosphere for the spiritual growth of the laity. Churches will have missed the purpose of their existence if they fail to develop the quality of life of their members. The following four principles are the spiritual principles that speak about the qualitative growth of the churches.

\section{Revival}

Revival is essential for members to be excited about their religion and keep the spirituality lively. Charles Finney expressed this idea as follows:

Men are so spiritually sluggish, there are so many things to lead their minds off from religion, and to oppose the influence of the Gospel, that it is necessary to raise an excitement among them, till the tide rises so high as to sweep away the opposing obstacles. They must be so excited that they will break over these counteracting influences, before they will obey God. ${ }^{1}$

The growth of the church in India is hindered by nominalism. Many Christians do not have a genuine, personal relationship with Jesus Christ. The solution is to have revival in the churches. Patrick Johnstone states:

${ }^{1}$ Charles Grandison Finney, what a Revival of Religion Is (London: Morgan and Scott, 1910), 2 . 
"Revival is sorely needed to rid the churches of selfseeking, social climbing, petty squabbles and sin; to implant a love for the brethren irrespective of social origin; and to give a burden to evangelize."1

McGavran points out the importance of revival in church growth: Realizing their own helplessness, people turn to God in prayer. God pours out the Holy spirit on them and they experience great joy and exultation. Sometimes the chief effect is in the mind. ${ }^{2}$ He further states:

The gift of the Holy Spirit enables men to confess sin, make restitution, break evil habits, lead victorious lives, persuade others of the available Power, bring multitudes to Christ and cause the church to grow mightily. ${ }^{3}$

For a revival to take place, thorough preparation is essential. According to Autrey there are two types of preparation for revival meetings consisting of preaching, praying, singing, visitation, and promotion. Organizational and spiritual preparation should be well balanced.

'Patrick Johnstone, Operation World (Carlisle, U.K.: Operation Mobilization, 1993), 275.

${ }^{2}$ Donald A. McGavran, Understanding Church Growth (Madras: Evangelical Literature Service, 1982), 170.

${ }^{3}$ Ibid. 


\section{Organizational Preparation}

1. At least three months before the revival meetings, the church should study the great revivals of the past.

2. Personal workers should be trained for the revival efforts.

3. The church should carry out publicity to create interest and popularize the revival meetings.

4. Personal assignments should be given to responsible people several weeks before starting the revival meeting.

\section{Spiritual Preparation}

1. The spiritual life of the church must be deepened by earnest prayers and study of the Scriptures.

2. People should be led to a great concern for their salvation.

3. There must be complete surrender. ${ }^{1}$

Smith, quoting 2 Chr 7:14, gives four conditions for revival to take place: to be humble, pray earnestly, seek God's face, and to turn to God. ${ }^{2}$ McGavran emphasizes earnest prayer and deep Bible study as the precondition for

${ }^{1}$ C. E. Autrey, Basic Evangelism (Grand Rapids: Zondervan, 1981), 107-119.

${ }^{2}$ Paul B. Smith, The Church on the Brink (Wheaton, Illinois: Tyndale, 1997), 36-47. 
revival. ${ }^{1}$

Having a personal experience with the Savior and living according to one's faith can bring revival to an individual and to a large group. Others will join in seeking God after seeing how God has changed the life of the person or the group. ${ }^{2}$ Such a change will bring awakening in the church and help the church become more lively and grow mightily. Revival has certain effects on the church. Smith points out the following: (1) unity and fellowship under the leadership of the Holy Spirit; (2) a burning passion for lost souls; (3) effective testimony of people's life experiences; (4) the unconverted flocking to hear the word of God; (5) people living an effective Christian life; and (6) reality in Christian experience, living, and service. ${ }^{3}$ McGavran highlights the effects of revival in the churches in India. Revival leads to holy living and gives power to live the Christian life. Revival drives believers to proclaim the gospel. ${ }^{4}$

'McGavran, Understanding Church Growth, 164-166.

${ }^{2}$ E. G. White, Christian service (Washington, D.C.: Gerneral Conference of Seventh-day Adventists, 1947), 256. ${ }^{3}$ Smith, $48-74$. ${ }^{4}$ McGavran, Understanding Church Growth, 167-169. 
Spiritual Life of the Church

The church is the spiritual body of Christ ( 1 Cor $12: 27,28)$. In it believers exercise their spiritual Iife and develop into the perfection of Christ.

Developing spiritual life is of vital importance to any church. The life of the congregation either attracts the unchurched to join the fellowship of the church or weakens the faith of those who are already part of it. "Passionate spirituality," which is Christians living committed lives and practicing their faith with joy and enthusiasm and then sharing it with others, is the goal for every congregation. ${ }^{1}$ The church is the body of Christ and should be healthy and growing daily. One of the basic aspects of the spiritual life of the church is exercising love one to another. While on this earth Christ demonstrated the depth of His love (John 15:13). His followers are to do the same. Kraus emphasizes that when the needs of the members in a congregation are met and genuine love for each other is exhibited, churches grow. ${ }^{2}$ Schwarz points out that love within the congregation creates a long-term growth

${ }^{1}$ Christian A. Schwarz, Natural Church Development (Carol Stream, Illinois: Church Smart, 1996), 26, 27.

${ }^{2}$ C. Norman Kraus, ed., Missions, Evangelism and Church Growth (Kitchner, Ontario: Herald, 1980), 111. 
potential. He further states that love is expressed in acts such as inviting each other for meals, and meeting each other's needs and problems. Schwarz concludes: "Practical love has a divinely generated magnetic power far more effective than evangelistic programs which depend almost entirely on verbal communication."1 People will be drawn to church when they see love having its effect among the congregation. Congregational growth depends upon the attitude of the members. Kraus states that members should be "warm and enthusiastic about their faith, their congregation, and their pastor."

Fellowship with one another in the church is one of the signs of the spiritual growth of a church. One of the twelve principles of church growth that B. Richard Storm finds in the Book of Acts is "the vibrant life of the Christian community," which is an unselfish, warm, and helpful fellowship. This fellowship has two main results: witness to unbelievers (Acts $2: 47$ ) and preparation for present and future ministry. ${ }^{3}$ Referring to Paul's

${ }^{1}$ Schwarz, 36 .

${ }^{2}$ Kraus, 113 .

${ }^{3} B$. Richard Storm, "Church Growth Principles from the Book of Acts," India Church Growth Quarterly 6 (JanuaryMarch 1985): 72 . 
expression "in Christ" or "in the Lord," Elliot states that these terms mean to be in mystical union and personal fellowship with Christ (Gal 3:27). Even more, the phrase means to be in fellowship with the community of Christ, the church. It is not mere togetherness but sharing in the body of Christ and being part of it ( 1 Cor $12: 12$ ). ${ }^{1}$

Reeves and Jenson note that for a congregation to grow it must have three specific qualities: (1) a clean and positive self-image accompanied by seeing the unchurched as brothers, (2) a strong philosophy of ministry and strong leadership ministry; (3) strictness regarding doctrines, membership, and other aspects of church life. ${ }^{2}$

The spiritual Iife of the church may be developed through power encounters. India is a land of many faiths and beliefs. The concept of different spirits, both good and evil, is not only believed but experienced. People are troubled and families disturbed by the spirits. Disasters, sickness, and suffering are understood to be caused by evil powers. Demon possession is widespread. Helping people to

${ }^{1}$ Ralph H. Elliot, A Church Growth That Counts (Valley Forge: Judson, 1982), 50, 51 .

${ }^{2} \mathrm{R}$. Daniel Reeves and Ronald Jenson, Always Advancing: Modern Strategies for Church Growth (San Bernardino, Calirornia: Here's Life, 1984), 21. 
find freedom from evil spirits through "power encounters" is needed in India. Power encounters are practical, visible demonstrations that Jesus Christ is more powerful than the spirits or demons worshipped and feared by a group of people.

Ezra Sargunam, in a case study in the Indian setting, states that a large number of converts are brought into the church by power encounters. ${ }^{1}$ People in the Indian church expect spiritual vitality and evangelism that stresses the power of God over evil. Churches should be centers of spiritual experience where the power of the Holy spirit can be seen and experienced in everyday life. ${ }^{2}$ Zechariah Chelliah points out that "all over the world miracles and healing have played a great part in bringing the multitudes to Christ." He notes that churches in India must begin to trust God to demonstrate His power in the daily lives of the common people. ${ }^{3}$

${ }^{1}$ Ezra Sargunam, "Experiments in Applied Strategy," India Church Growth Quarterly 1 (October-December 1979): 56.

${ }^{2}$ Roger E. Hedlund, Evangelization and Church Growth (Madras: McGavran Institute, 1992), 182, 183.

${ }^{3}$ Zechariah Chelliah, "Seven Growth Principles for India," India Church Growth Quarterly 2 (July-September 1980): 98 . 
Worship

One of the basic purposes of the existence of a church is to worship the Lord. Meeting God in spirit should be the highest spiritual experience of the believers. Logan points to worship as "an active response to the person and work of God." This worship is multi-dimensional, deep, and complex. ${ }^{1}$

Worship involves both mind and heart. Kraus states, "True spiritual worship is pivotal to the total ministry of the church. . . The church is the temple in which God's Spirit dwells, and recognition of this fact is basic to all else." ${ }^{2}$

Worship should be an "inspiring experience," in which the presence of the Holy spirit is concretely experienced by the entire gathering. Such worship will change the church in quality and quantity. ${ }^{3}$ Rick Warren advises to design a service "so attractive, appealing, and relevant to the unchurched that your members are eager to share it with the

'Robert E. Logan, Beyond Church Growth (Grand Rapids: Fleming H. Revell, 1996), 76.

${ }^{2}$ Kraus, 115 .

${ }^{3}$ Schwarz, $30-31$. 
lost people they care about." 1

Worship is an activity within a time limit as well as a life-long activity. It is a personal as well as a corporate activity, in which diverse gifts are used. In true worship believers exalt Christ and every individual is uplifted. ${ }^{2}$

Worship should be lively and spirit filled. God's presence should be felt through singing hymns, reading Scripture, and prayer. The weekly worship services should be holistic in music and message, corporately planned, and led by a compassionate, competent team of laity and pastor. ${ }^{3}$ Logan states:

True worship is not static activity, but a dynamic process of receiving vision from God. . . .

Quality, dynamic worship is one of the most attractive forces in a growing church. . . .

A very definite correlation exists between a wellplanned and vital worship and the ability of a church to communicate positive and meaningful christianity to the unchurched. ${ }^{4}$

Worship must be strategic to be successful. Every element of worship should be well planned. Logan gives four factors for a successful strategic worship: (1) The worship

${ }^{1}$ Warren, 253.

${ }^{2}$ Logan, 77-79.

${ }^{3}$ Kennon L. Callahan, Twelve Keys to an Effective Church (New York: Harper and Row, 1983), xiii.

${ }^{4}$ Logan, 79, 80 . 
leader must plan well and in advance the mode of worship desired; (2) worship must have a clear theme and focus; there should be a smooth and rapid flow in dynamic strategic worship; (4) there should be maximum audience participation in worship. ${ }^{1}$

Worship in a local style is more effective than in a style borrowed from others. Ponraj stresses the contextualization of worship in people's particular cultural context. Prayer books, hymnals, and musical instruments should be contextualized, without compromising the biblical idea of church. Postures of worship such as sitting on the floor, removing the shoes, and kneeling for prayer should be contextualized. Familiar terms of worship should be encouraged. ${ }^{2}$

Music in worship gives rhythm and melody to the whole atmosphere of the service. The message presented through songs has more effect than in any other form.

Rick Warren states that "music can bypass intellectual barriers and take the message straight to the heart. It is a potent tool for evangelism." He admits that there cannot

$$
\text { 'Ibid., 87-89. }
$$

${ }^{2}$ S. Devasagayam Ponraj, Church Growth Studies in Mission (Lalgarh, Madhupur: Indian Institute of Multicultural Studies, 1988), 45. 
be one style of music that will please everyone. Thus, selecting music that will attract the unchurched is very important. The choice should be made according to the background and culture of the target group. Warren further feels that there is no such thing as sacred music; he notes that the message and the words make music sacred and spiritual. ${ }^{1}$

Warren gives four broad rules for selecting music for the unchurched: (1) The music that is used must be updated; (2) the tempo of the music should be speeded up; (3) the lyrics should be updated; and (4) members should be encouraged to write new songs. ${ }^{2}$

\section{Discipleship of Members}

Successful church growth involves the discipleship of the laity. Logan affirms that "disciple making is the foundational scriptural vision of churches." ${ }^{3}$ It is the imperative that Christ gave in the great commission to His disciples (Matt 28:19-20). In its four action words--go, make disciples, baptize, and teach--the imperative and goal

\footnotetext{
${ }^{1}$ Warren, 277-281.

${ }^{2}$ Ibid., 286-288.

${ }^{3}$ Logan, 30 .
} 
is to make disciples. This is done by going, baptizing and teaching people. Nelson defines disciples as persons who have "repented and believed in Jesus Christ. Their lives are changed (2 Cor 5:17). The names of these persons are in the Lamb's Book of Life" (Phil 4:3). ${ }^{1}$

Ralph Elliot states that discipleship is more important than mere decision-making. He further states that the brief process of decision-making at the initial stage should lead to a life-long process of discipleship. ${ }^{2}$ Kraus states that "discipling is evangelism" and post-baptismal nurture is "perfecting."

The task of perfecting a disciple must be given priority in order to bring maturity and spirituality to the new members. This perfecting brings ethical change, leading to a thoroughly Christian way of life. ${ }^{3}$

For the perfecting and maturing process, emphasis should be placed on small-group fellowships. Small groups, such as Bible study groups, discussion groups, music groups, youth groups, service groups, fellowship groups, and prayer

${ }^{1}$ Marlin L. Nelson, Principles of Church Growth

(Bangalore: Acts Trust, 1995), 41.

${ }^{2}$ Elliot, 47 .

${ }^{3}$ Kraus, 147 . 
groups help nurture people. These are an integral part of any large congregation and help mature those who have committed their lives to Christ for reaching out to others. Emphasis is placed on Bible study, which helps intellectual and emotional growth.'

Schwarz suggests "holistic small groups" in which personal issues and questions are brought up. In these groups Christians serve each other with their spiritual gifts, discipleship becomes practical, and people are led to total life transformation. These small groups multiply through cell division. ${ }^{2}$

An expanding network of cell groups helps both the discipleship of members and the growth of the church. Logan states that through cell groups a church can minister to every member if the groups are properly planned. Alone the pastor cannot minister to all the members in an effective way. ${ }^{3}$ Callahan states that missional churches constantly and intentionally start new caring groups where people find "roots, place and belonging." 4

${ }^{1}$ Elliot, 48 .

${ }^{2}$ Schwarz, $32-33$.

${ }^{3}$ Logan, 120.

${ }^{4}$ Callahan, xiil. 
According to Logan, in the process of "holistic disciple making," there are two imperatives. The first is the sending imperative: "Go therefore." The second is the making imperative: "and make disciples." Obeying these imperatives and having Christ's compassion for the lost are the qualities needed in lay leadership. ${ }^{1}$

\section{Strategic Principles}

To think about church growth in terms of qualitative or numerical growth is to think in terms of strategy. Achieving numerical growth through a systematic strategy is essential for church growth. ${ }^{2}$ The great commission (Matt 28:19) given by our Master demands it. He told us to reach all the corners of the world (quantitative growth) and make disciples of all nations (qualitative growth). The following four principles speak about the strategic principles that lead to quantitative growth in the church.

\section{Leadership}

The growth of the church is dependent upon the type of leadership that the church receives. The pastor and the lay leaders are the key persons to bring about change in the

\footnotetext{
${ }^{1}$ Logan, 94, 96, 100 .

${ }^{2} \mathrm{Nelson}, 39$.
} 
church.

\section{Pastoral Leadership}

The pastor of a church, as the shepherd of the flock, imitates the true shepherd, Jesus Christ, in leading and nurturing the members to be better fitted for His kingdom (John 21:15-17). The church members look to the pastor as their spiritual leader and spiritual role model.

The pastor should be a deeply spiritual person and have a vision for church growth. A pastor should always feel the call of God and should feel a burden for His cause. Despite his weaknesses and failures he needs to fully depend upon the Holy Spirit and do his part faithfully. Logan states that "it is the personal vision of a pastor or church planter, and his or her ability to communicate that vision, that drives churches to growth."1 In order to help churches grow, according to Logan, some of the qualities of a pastor must be: honesty, worthiness of the members' trust, and competence. The pastor must be forward looking and be able to give members a sense of security, direction, and vision. A dynamic pastor strives to develop godly character in the lives of those he leads. The pastor aims at numerical

\footnotetext{
${ }^{1}$ Logan, 34 .
} 
growth of members and also at the multiplication of churches. ${ }^{1}$

A successful pastor is one "who is a possibility thinker and whose dynamic leadership has been used to catalyze the entire church into action for growth."2 Logan states that growing churches are generally led by sodalic (task-oriented) pastors who are gifted with the qualities of leadership and faith, who can see the potential in their members, and who can equip them and challenge them to dedicate themselves to church growth and multiplication. ${ }^{3}$

In the opinion of Kraus the real strength of a pastor is knowing how "to deal constructively with conflict; how to preach the word of God with power; how to lead in meaningful worship; how to be sensitive to personal needs; how to generate enthusiasm." ${ }^{4}$

The length of time a pastor stays in one place is an important factor in being effective. Longevity develops a

${ }^{1}$ Ibid., 38-40.

${ }^{2} \mathrm{C}$. Peter Wagner, Your Church Can Grow (Ventura, California: Regal, 1976), 187.

${ }^{3} \operatorname{Logan}, 43$.

${ }^{4}$ Kraus, 113, 114 . 
deep, trusting, and caring relationship. ${ }^{1}$ Since it takes seven to twelve years to energize an established congregation, it would seem that church administrators should not move pastors so frequently that they do not have time to develop the needed relationships for effective ministry ${ }^{2}$,

\section{Lay Leadership}

Lay members are the key components of a church. The growth and multiplication of a church depend upon the spiritual and leadership quality development of the members. Lay leaders who have similar experiences and felt needs as their brethren are the best leaders.

Ponraj points out that it is also of vital importance "to train, develop and produce people who can lead the local church, handle the local problems, give spiritual nurture and reach out to unsaved people in order to help the church to grow." ${ }^{3}$ This is essential because all the members do not have the same potential and urge to lead and develop the churches.

\footnotetext{
${ }^{1}$ Logan, 31 .

${ }^{2}$ Reeves and Jenson, 24.

${ }^{3}$ Ponraj., 49 .
} 
It is necessary to recognize the potential and spiritual gifts in the members and persuade them of the vital importance of their role in the growth and development of the church. Then they should be trained to lead the church effectively. Failure to recognize their role and importance will hinder church growth, both spiritually and numerically. Classifying the members by their potential, skills, and interests is essential. ${ }^{1}$

Different models of lay training could be used. The model should suit the time and place. Logan presents a biblical model in these words: "Orient, involve, and equip." This entails orientation for a potential cell group; involving lay leaders, with new lay leaders placed as apprentices in cell groups under existing leaders; and equipping lay leaders of the new cell group through teaching, skill seminars, and through involving them in meetings. ${ }^{2}$

Nelson suggests an "on-the-job" training process to involve lay leaders in personal ministry so that they will become effective soul winners. Witnessing will also help the spiritual development of lay leaders. As they begin to

$$
\begin{aligned}
& { }^{1} \text { Nelson, 86-87. } \\
& { }^{2} \text { Logan, 147-148. }
\end{aligned}
$$


witness, they will realize their need for greater faith. Their sense of need will then be an additional reason for them to spend time in Bible study and prayer. ${ }^{1}$

\section{Evangelism}

While the first purpose of the church may be to worship and glorify the Lord, the second is to evangelize the world. R. R. Cunville feels that church growth is based on bringing men and women into a personal relationship with Jesus Christ and into church fellowship. ${ }^{2}$ This great task is based upon the Savior's command to make disciples of all nations. Christ commanded: "Go ye therefore, and teach all nations, baptizing them in the name of the Father, and of the son, and of the Holy Ghost, teaching them to observe all things whatsoever I have commanded you" (Matt 28:19, 20). The basic biblical principles in this commission are to "preach, persuade, and plant." ${ }^{3}$ Like the Master, every disciple is to seek, find, and save the 1ost. This mission of God is a

${ }^{1}$ Nelson, 77 .

${ }^{2} \mathrm{R}$. R. Cunville, "Our Task in India," India Church Growth Quarterly 1 (January-March 1979): 5 .

${ }^{3}$ Chelliah, 98 . 
divine-human task. ${ }^{1}$

Evangelism is the most effective means of church growth. Evangelism includes adding members to the church and also adding to the number of churches. Evangelism, "seeking and saving sinners, means finding the lost children and bringing them rejoicing into God's household."2

Evangelism and church growth should go together. "Evangelism-in-depth is a potential avenue for the application of church growth principles in many mission fields around the world." ${ }^{3}$ Hedlund points out that

church growth theory is founded upon a classical theory of evangelization. . . . Church growth is not mere pragmatism derived from the social sciences, it is a dynamic theologizing which takes seriously the human context as well as the biblical text. ${ }^{4}$

Regarding the importance of evangelism in the local church, Hedlund states: "Growing churches have a strong sense of the church as the agent for evangelization and nurture." 5 He also affirms: "Evangelism must be at the heart of the local

${ }^{1}$ George David, "Principles for Indigenous Missions," India Church Growth Quarterly 12 (July-September 1990): 101.

${ }^{2}$ Chelliah, 98.

${ }^{3}$ Malcolm R. Bradshaw, "A Thought," India Church Growth Quarterly 2 (July-September 1980): 105 .

${ }^{4}$ Hedlund, Evangelization and Church Growth, 41.

${ }^{5}$ Ibid. , 178 . 
church, and its periphery, and it must be owned by the local Christians. This never happens through a committee or conference." 1

Wagner states that there is no particular evangelistic method that fits all churches. Thus, methods that fit the individual church, attracting new members, making disciples, must be chosen. ${ }^{2}$

Nelson suggests an effective strategy. The right goal, he says, is to make disciples. As these disciples attend church they should be trained to witness to their relatives and friends. Next, one must go to the right place at the right time. This means going to the more responsive people. Right methods are needed. Some of these are contacting unbelievers and presenting the gospel to them. Also, new believers should be encouraged to attend church and read their Bible regularly. The right people to do the work are needed; they must be zealous to spread the gospel. ${ }^{3}$

Evangelism is more effective when members make personal contact with their friends and relatives. Logan states that members should be helped to identify their network of

\footnotetext{
${ }^{1}$ Ibid. , 181

${ }^{2}$ Wagner, Let Your Church Grow, 38.

${ }^{3}$ Nelson, $47-53$.
} 
relationship--family, friends, co-workers, neighbors, and others--for whom they will pray and with whom they will share the word of God." Ponraj states: "As the new believers live and move with their non-Christian relatives and friends they make effective witness and bring people to Christ and plant new churches." 2

The approach to evangelism should be culturally relevant. Logan states that flexible methods must be adapted to fit the culture of the target groups. For him, to be culturally relevant is to incarnate the gospel. "It means putting good news into forms that relate and communicate to people where they are." ${ }^{3}$

The ideal approach in evangelism should be directed to receptive people rather than resistant ones. Eddie Gibbs suggests reaching out to "people who find themselves disoriented by unfamiliar surroundings or distressed by life crises." People in transition or trauma are more approachable. ${ }^{4}$ Chelliah has observed that common people are

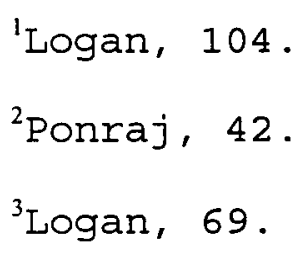

${ }^{4}$ Eddie Gibbs, "The Power Behind the Principles," in Church Growth: State of the Art (Wheaton, Illinois: Tyndale, 1986), 192 . 
more receptive to evangelism than those of higher classes. ${ }^{1}$ Evangelism through power encounters is effective in India. Sargunam noticed that a large number of his converts had come to belief through power encounters. ${ }^{2}$ Spiritual vitality in a church is essential. Hedlund states, "Evangelization takes place in a context of power and counter power. Churches are expected to be centers of life, light and spiritual reality."3

One of the most effective methods of church growth is urban evangelism. Cities and towns must be evangelized first. Because evangelism grows faster in these places, when these have become centers of evangelism, the message can easily be carried to the outlying villages by individuals and families who have migrated from these areas. ${ }^{4}$

\section{New Unit Principle}

The new unit principle, starting altogether new groups or churches, fully unattached to the old churches, is a much

${ }^{1}$ Chelliah, 98.

${ }^{2}$ Sarganum, 56 .

${ }^{3}$ Hedlund, Evangelization and Church Growth, 182, 183. ${ }^{4}$ Ponraj, 78. 
better strategy than trying to revive a nominal, cold, entrenched group of believers. Kraus states, "A sign of healthy growth is the multiplication of new fellowships. Growing churches look for places to plant new congregations." 1

Miles "emphasizes the importance of new units.

Much as the fruit of a grapevine is produced on the new growth, so the fruit of church growth comes from new units, new members, new churches, new missions, new associations, new state conventions, new denominations, new Sunday Schools, new departments, new classes, new units of almost any kind and description.

Growth always comes on the new growth. ${ }^{2}$ New people integrated into an organization bring growth. New units that enlarge the organization bring growth. New organizational units that offer a variety of ministries bring growth. New space in which the organization may function brings growth. New leadership in the organization can produce growth. ${ }^{3}$

Any church interested in expansion growth must always think of adding new Bible study cells, new classes, or new departments. Significant growth occurs much more easily in a newly started church than in an old one. ${ }^{4}$

In India, it is important to start new house churches,

${ }^{1}$ Kraus, 119, 120 .

${ }^{2}$ Dale Miles, Church Growth: A Mighty River (Nashville: Broadman, 1981), 94 .

${ }^{3}$ Ibid. , 95.

${ }^{4}$ Ibid. , 95-96. 
rather than merely adding more members to old churches. Hedlund presents the significance of house churches: "The house church phenomenon is central to understanding both the spread of the gospel and significant partnership of men and women."1 This approach effectively follows the new unit principle.

House churches are appropriate in several ways. Constructing a church building is a costly affair for many poor Christians. George David finds house churches useful for many poorer localities and slum areas, as well as to reach Hindus. He states: "This provides many opportunities for informal, friendly, spontaneous witness and service, leading to many conversions." ${ }^{2}$

People are scattered and it is inconvenient to attend the main church. Distance adversely affects church attendance. Sargunam's experience with young converts and non-Christians is that it is easier for them to gather in a house for prayer or Bible study than to attend a church. ${ }^{3}$ When there are small groups in a house church it is easy for the members to grow spiritually, to help each other, and to

\footnotetext{
${ }^{1}$ Hedlund, Evangelization and Church Growth, 171.

${ }^{2}$ David, 102

${ }^{3}$ Sargunam, 57 .
} 
reach others in the neighborhood. Chelliah points to the New Testament method of house churches as providing an effective basis for church growth. Through house churches, neighbors and friends can be reached; people can meet with their own kind and find their inner needs met. ${ }^{1}$

\section{People Movements}

A people movement "is a multi-individual, mutually interdependent" ${ }^{2}$ decision for Christ. These are decisions for Christ where many people participate in the discussion as to whether or not to follow Christ, but each person makes up his or her own mind. Ponraj states that a people movement "is a group of people who move into the Church with a common commitment to follow Christ." ${ }^{3}$ Among tribal peoples this approach is highly effective. There are both positive and negative results in India from using a people movement approach.

Nelson sees a people movement as an effective means to reach different castes and communities in India. "For Muslims, Hindus and others, the greatest obstacles to

${ }^{1}$ Chelliah, 98.

${ }^{2}$ McGavran, Understanding Church Growth, 302 . ${ }^{3}$ Ponraj, 9. 
conversion are social, not theological." 1 Accepting a new faith could mean excommunication from one's society, loss of social and economic privileges, and could even result in being forced off of village land. In such situations a people movement is much healthier than individual conversions. Since in a people movement a large number of families in a village or tribe accept Christ at the same time, they can support each other in their new faith. India is a land of many religions and of various communities. It is largely a Hindu country. Though India has religious liberty and a secular government, due to the attitude of a number of militant groups and political parties, conversion in large numbers would be violently opposed in some parts of India. People movements could take place openly in non-Hindu villages in south India and among tribal peoples; however, in North India, including Maharashtra, it may not work as well as in other places. Hedlund recognizes this situation by stating that in Maharashtra and some other states, the pattern of conversion is one by one. ${ }^{2}$

${ }^{1}$ Nelson, 100.

${ }^{2}$ Roger E. Hedlund, Building the Churches (Madras: Evangelical Literature Services, 1982), 64-65. 
McGavran advocated a people movement as the most effective method of evangelism for countries where there are so many unreached peoples like India. Yet he too saw limitations.

In tightly-structured societies, where Christianity is looked on as an invading religion, and individuals are excluded for serious faults, there to win converts from several different segments of society, far from building bridges of each of these, erects barriers difficult to cross. ${ }^{1}$

In such a situation, McGavran states, "sometimes oneby-one is the only possible method." ${ }^{2}$ The people-movement principle should be followed wherever possible, but in the large cities and in predominately Hindu areas the church will continue to call individuals to faith in Jesus Christ.

\section{Balancing Qualitative and Quantitative Church Growth}

The spiritual principles that lead to qualitative growth of the church and strategic principles that lead to the quantitative growth of the church have been considered. One of the basic principles of church growth is the balancing of qualitative and quantitative growth. These two

'Donald A. McGavran, "A Church in Every People: Plain Talk about a Different Task," India Church Growth Quarterly 3 (July-September 1996): 6 .

${ }^{2}$ Ibid. , 10, 11 . 
important aspects need to be given careful consideration since an imbalance between the two types of growth can hamper growth in a church. There must be balance between evangelism and nurture, between outreach and discipleship. For continued church growth, the nurturing of believers towards maturity needs to be balanced with on-going evangelistic programs. ${ }^{1}$

Nelson sees quality and quantity as two aspects of the same reality. He states that "the goal in evangelism is to make disciples with persuasion, and not just get new baptized members. These new disciples witness to others and thus new believers are added to the church. In this way the church grows and new churches are established." ${ }^{2}$

Qualitative growth or spiritual nurture and quantitative or numerical growth do not stand in opposition to each other. Neither is achieved at the expense of the other; both are important and necessary. Warren sees a church as being unhealthy if quality and quantity are not balanced. He states:

Quality refers to the kind of disciples a church produces. Quantity refers to the number of disciples a church produces. . .

\footnotetext{
${ }^{1}$ Reeves and Jenson, 30 .

${ }^{2}$ Nelson, $45-47$.
} 
Quality produces quantity. A church full of genuinely changed people attracts others. . .

Quality attracts quantity. ${ }^{1}$

The principles of church growth are worked out through different methods. Methods differ from church to church, depending upon their effectiveness in a particular setting. Warren states that principles should be discovered which are "biblical, cultural and leadership principles--that produce healthy, growing churches." ${ }^{2}$

Balance of the principles undergirding church growth is vital. In his study of the eight characteristics of growing churches, Schwarz states that the key to church growth is "in the harmonious interplay of all eight elements." ${ }^{3} \mathrm{He}$ stresses "the minimum strategy" for churches where growth is blocked by the quality characteristic that is least developed. Focusing energy primarily on these minimum factors alone can lead to growth. ${ }^{4}$

\section{The Holy Spirit in Church Growth}

Following the applicable principles and methods for

\footnotetext{
'Warren, 51.

${ }^{2}$ Ibid. , 30 .

${ }^{3}$ Schwarz, 38,39 .

${ }^{4}$ Ibid. , 50, 51 .
} 
church growth is important. Above this, the power and guidance of the Holy Spirit are essential.

Church growth is the work of God. Human beings are instrumentalities in God's hand to be effectively used for His cause. This is accomplished through the agency of the Holy Spirit. This process has been followed throughout human history and is effective even today. E. G. White states:

From the beginning God has been working by His Holy Spirit through human instrumentalities for the accomplishment of His purpose in behalf of the fallen race. This was manifest in the lives of the patriarchs. To the church in the wilderness also, in the time of Moses, God gave his "Good Spirit to instruct them." And in the days of the apostles He wrought mightily for His church through the agency of the Holy spirit. The same power that sustained the patriarchs, that gave $\mathrm{Caleb}$ and Joshua faith and courage, and that made the work of the apostolic church effective, has upheld God's faithful children in every succeeding age. ${ }^{1}$

The Holy spirit gives complete power to bring about church growth, but the church must be completely under the guidance of the Holy Spirit. Ellen White wrote: "We cannot use the Holy Spirit. The Spirit is to use us. "2 Human beings cannot depend merely upon their intellect and skills. The principles and methods applied in church growth need to

${ }^{1}$ White, Christian Service, 256.

${ }^{2}$ Ibid. , 253 . 
be totally controlled and guided by the Holy spirit. The Holy Spirit is the full power behind the principles and the methods used for church growth.

Church growth in the Indian style is fully dependent on the power of the Holy Spirit. Hedlund states: "The powerful presence of the Spirit is essential for the Church to carry out its mission of evangelization among animistic tribes as well as Hinduized people in India." ${ }^{1}$

${ }^{1}$ Hedlund, Evangelization and Church Growth, 232. 
CHAPTER 3

THREE MODEL, GROWING CHURCHES

This chapter describes three model, growing churches belonging to different denominations, in various parts of Maharashtra. These churches are viewed from the perspective of the church-growth principles that they have followed. Applying the lessons learned from them should help SDA churches grow.

Patrick Johnstone states that in Maharashtra Christians are few outside the cities of Bombay and Pune. ${ }^{1}$ In 1995, 7 percent of Bombay's 12,569,978 inhabitants were Christians. This is the highest percentage in the state of Maharashtra and second highest of the major cities of India. ${ }^{2}$ Taking this into consideration, two prominent churches from Pune and Bombay were selected as model churches, the Pune New Life Center and the Bombay Free Methodist Church. A third

'Johnstone, 275.

${ }^{2}$ Albert S. Vasantharaj, "A Portrait of India," study material prepared for Global Consultation of World Evangelism, 1995, 218. 
church, Bethel Savior's Alliance Church, in Akola, from northern Maharashtra, was also chosen.

\section{New Life Centre}

Description

Pentecostal churches in Maharashtra and other states of India are growing rapidly. Their spiritual life, fellowship, and outreach programs are attracting more and more people into their congregations. Information gathered regarding the New Life Centre was obtained from a questionnaire filled out by the present associate pastor, Daniel John, in consultation with various church leaders (see appendix A). Data were also obtained from available church records. In addition, personal interviews were conducted with some of the key members.

The New Life Centre is more than twenty-eight years old. The membership in 1995 was 300 , with 400 attending. In 1999 it was 450 . This gives a growth rate of (DGR) 8.3 percent. Its senior pastor, Timothy John, has served for twenty-seven years. The present associate pastor has been serving the church for seven years.

The motto of the church is "Save, Build and Send." Based on this motto, the main events and major programs that 
have taken place during the last five years have been crusades and conferences. Evangelistic crusades to reach out to unbelievers are held annually. The church has also conducted two conferences aimed at strengthening the church. According to the questionnaire responses, approximately 40 percent of the members are involved in the evangelistic programs of the New Life Centre. On a scale of 1-5 (with 5 being very active), those between the ages of 20 and 50 were reported as being the most active (rated at 4 ). The participation of those under 19 and of those 51 to 65 was rated at 3 .

The main evangelistic methods followed in the New Life Centre are conducting cottage meetings, visiting, and having major evangelistic crusades continued by strong follow-up work. The main principles that have helped the growth of New Life Centre are (1) encouraging all members to reach out to their neighbors, and (2) encouraging all members to pray for the lost. Prayer, both daily and during a monthly allday prayer meeting, contributes to the strength of the New Life Centre. The group also emphasizes the working of the Holy Spirit by allowing Him to have His way.

on a scale of 1 to 5 the spiritual condition of the church, fellowship in the church, and the effect of music 
in worship were each given a rating of 4 . This shows the importance given to all three elements.

One of the major aspects of the spiritual growth of this church is the warmth of fellowship among its believers. Warm fellowship in this church is attributed to the working of the Holy Spirit. The pastor states: "We are allowing Him to move in our midst in a mighty way."

Another means used to promote the spiritual growth of the church is a highly effective music program that blends Western and Eastern music. Music in this church is a major way to praise and worship the Lord.

According to the associate pastor, efforts made to further strengthen the spiritual condition of the church include teaching God's word and taking time to pray for people after the service. Other events, such as conferences and schools for fellowship and encouragement, are also often arranged.

The inactive membership of the New Life Centre is 50 percent. The methods used to encourage members to become active again include personal visits and giving pastoral counsel. The newly baptized are strengthened and activated by cottage meetings and through Bible studies. According to the church pastor, four areas of church 
life are targeted for increased emphasis. The church would like to have worship services on other week nights, in addition to the mid-week and Sunday services. Another goal is to teach and practice hungering after the word of God. Further grounding in God's word is needed, perhaps by setting up a Bible school where members could study the Bible. Finally, improved prayer life of the members is a pastoral objective.

The church pastor mentions further plans for the growth of the church. More evangelism is planned by involving more lay people in street evangelism. More conferences for fellowship and for the study of the word of God are also being planned.

\section{Evaluation}

Some of the Indian church-growth principles that I observed in the New Life Centre included:

1. Complete trust and dependence on the power and working of the Holy Spirit in the lives of the believers and in the guidance of the church's mission

2. Emphasis on personal and corporate prayer

3. Effective and spirited music and hymns in worship

4. The longevity of the pastor as a contributing factor 
to church growth

5. A large number of lay people mobilized for outreach programs such as cottage meetings and visitation of homes

6. Spiritual growth, fostered by conferences to help the believers with their personal spiritual growth, fellowship; and prayer

7. Outreach programs, such as evangelistic crusades to reach the unreached.

In many aspects the methods and principles followed by the New Life Centre are general principles for church growth and are relevant to the broader Indian situation. The emphasis given to the role of the Holy spirit is relevant to churches throughout India, since many struggle with evil powers and spirits in their everyday life. The emphasis on personal and corporate prayer is appealing to the Indian mind, since many in India are seeking a closer contact with God through mysticism. The use of effective music in worship captures the minds and hearts of the worshipers. The longevity of the pastor provides continuity and experience in the leadership of the congregation. The emphasis on and use of the laity for the outreach of the church is focused not so much on large and costly programs as on attention to personal contacts. These methods and 
principles could be adopted by the Seventh-day Adventist Church.

Although there is a great deal of emphasis on mobilizing the laity, it appeared that there were not sufficient training programs for adequately equipping then for service.

\section{Free Methodist Church}

Description

The Free Methodist churches are doing well in Bombay and other parts of Maharashtra. The model selected was the Free Methodist church in Andheri, Bombay, which is part of a network of established churches. Information gathered from the church was obtained from a questionnaire filled out by the pastor of the church, William John, who is also the area director for the Free Methodist Church in Bombay.

The Free Methodist Church in Andheri, Bombay, was started in 1979. From its beginning this church has emphasized church planting. In the past twenty years the mother church has started thirty new churches and house groups. The statistical record from 1991 to 1996 shows a steady growth in membership. In 1991, the membership was 100; in 1996, it was 250. In 1998 the membership stood at 
1,250. In 1999 it was 1,400. This gives a growth of (DGR) 1800 percent. The churches have lived their motto: "Make Christ known to the nation; preach Christ crucified." The major events and programs that have taken place in this church have been the "Mumbai Harvest 1996," a youth conference on evangelism and mission in 1997, and the tenth anniversary of "Evangelism Equipping III India" (EEIII), the tenth anniversary of the use of the church premises in 1997, and leadership training through the Haggai Institute. ${ }^{2}$ Ten percent of the membership is involved in evangelism. On a scale of 1 to 5 men are rated at 4 and women at 3 for their involvement in church activities. The youth under 19 years are primarily involved in personal evangelism, conducting. Sunday schools and choirs, while members between the ages of 20 and 35 are involved in evangelistic programs. Active members between the ages of

${ }^{1}$ EEIII (Evangelism Equipping III India) is an international training institute that conducts one-week leadership training seminars for pastors and lay leaders for personal evangelism. III stands for evangelism, discipleship and church maturing. The head offices for India are in Delhi and Bangalore.

${ }^{2}$ The Haggai Institute is an international institute that conducts advanced leadership training for mature leaders such as pastors. They conduct different seminars such as weekend seminars, 5-day seminar, institutional seminars, and national seminars. The head office is in Atlanta, USA; for India it is in Hyderabad. 
36 and 50 years are mainly women who are involved in the women's ministries of the church.

The involvement of church members below 19 years of age was rated at 4 on a scale of 1-5. The involvement of those older was rated at 3. Much emphasis is placed on EEIII evangelism where lay members are trained, equipped, and sent out for evangelism.

Men are more involved in fasting, prayer, Bible study, and evangelism. Women are more involved in prayer meetings, regular home visitation, and conducting sunday school classes. The women's association, Mahila Mandal, ${ }^{1}$ is very active.

To activate the inactive members, the pastor is giving special attention to visiting and praying regularly for those he visits. The inactive members also are encouraged to read the word of God.

In the questionnaire, when asked to rate three aspects of the life of the congregation, the spiritual condition and fellowship were both rated at 3 . The effectiveness of the Eastern music in the worship service was rated at 4.

Factors which have helped this church grow are a strong

${ }^{1}$ Mahila Mandal: A group of women forming a cooperative association carrying out various activities for development in the social, economic, or religious fields. 
emphasis on prayer chains and fasting. Every day the church has at least one member or family fasting and praying. Special prayer programs include saturday morning prayer sessions and all-night prayer meetings the first saturday of every month. Another factor that helps this church grow is its strong emphasis on personal evangelism by the laity. Some of the evangelistic methods used are:

1. Literature is distributed at public gatherings and tracts are handed out door to door to the homes of people in the neighborhoods where the members live. Thus far church members have distributed more than 1,000,000 pieces of literature to more than 200,000 homes. The church takes advantage of local festivals and gatherings to give away thousands of pieces of Christian literature.

2. Many church members have been trained using the EEIII method for personal evangelism and have been taught how to bring people into the church.

3. Open-air preaching by groups of trained lay members is done in public places, such as railway stations and crowded streets.

4. Video films on the life of Jesus are shown throughout the city. People attending these programs often become contacts for future events and many become 
interested in the gospel.

The main evangelistic activities followed by the Free Methodist church at Andheri, Bombay, are fasting, prayer, EEIII evangelism, home visits, and follow-up work.

The pastor is presently concentrating on three areas where he would like to see additional growth and development in his church. They are (1) church planting, (2) leadership training, and (3) children's ministry.

\section{Evaluation}

In the Free Methodist Church the main points in agreement with generally accepted church-growth principles in an Indian context are as follows:

1. The longevity of pastoral leadership is a contributing factor for church growth.

2. There is a strong emphasis on church planting and small prayer groups.

3. Several evangelistic programs are scheduled each year. There are also regular youth and lay training programs. This church has also adopted research-based programs from various othex churches or groups, such as EEIII evangelism and training programs conducted by the Haggai Institute. 
4. Only 10 percent of the members are involved in the church's evangelistic programs, but they are well trained and equipped. On-the-job training is widespread. In fact, the number of youth involved in evangelism has increased the vitality of the programs. The women's association, Mahila Mandal, is a strong contributing factor to evangelism in the Indian environment. Large-scale tract distribution and oneto-one evangelism are also effectively used.

The spiritual life and fellowship are seen as satisfactory, with a rating of 3 on a scale of $1-5$. There is a good emphasis on music with a positive rating of 4 . There is a powerful. emphasis on prayer. These elements contribute to church growth and could be adopted by other Indian churches.

\section{Bethel Savior's Alliance Church}

\section{Description}

The Alliance churches are doing well in Bombay, Pune, and the northern parts of Maharashtra. Alliance Churches seem to be paying close attention to fellowship, spiritual worship, and outreach programs.

The Bethel Savior's Alliance Church at Akola, in the northern part of Maharashtra, was selected as another model 
church. In this area of Maharashtra, Alliance Churches have active evangelistic networks in both rural and urban areas. Data for this church were gathered by a questionnaire that was filled out by the present pastor, D. G. Dongardive, in consultation with various church leaders.

In 1885, Dr. Rev. A. B. Simpson founded Alliance churches in Akola. Bethel Savior's Alliance church was started in 1980, as a division of the main church. Its present pastor has been serving since Alliance Church activities were started in this area. The growth rate has been slow: in 1991 there were 137 members, and also in 1996, 137. In 1999 the membership stood at 140. This gives a growth rate (DGR) of 2.2 percent. ${ }^{1}$

The church members cooperate with their pastor. This is seen in the challenge made by the pastor to his members to contribute financially for a new church building. This project was very successful. The higher church organization also contributed to the growth of this church by providing some financial support for the new building.

The motto of this church is "Spreading the Gospel and

${ }^{1}$ Membership figures originally provided placed the church in the category of growing church with a DGR of 62.9 . At the end of the research, the revised numbers showed a different picture. 
getting people ready for the second coming of Christ." The main events and programs planned in the church during the last eight years include evangelistic meetings held yearly in the church, the celebration of the church anniversary, crusades, and spiritual meetings held on a regular basis. Ten percent of the members are active in soul winning. Young people, 19 years and below, help with Sunday schools and youth groups. Their participation was rated 3 on a 1-to-5 scale. People between ages 20 and 35 are helping with home visitation and prayer. Those between the ages of 35 and 65 are also largely engaged in home visitation and prayer groups. The participation of both age groups was rated at 4 . Persons older than 65 also join in the same type of activities, but their activity level was only rated at 2 on a scale of 1 to 5 . Men and women alike are engaged in visiting people in rural areas and church members in the city. Emphasis is placed on personal visitation to members' homes and also to homes of unreached people in the community. The members and the church pastor do visitation. These visits emphasize prayer and the distribution of tracts. The financial basis of the church is strong. The pastor reported that 80 percent of the people give tithe. Those responding to the questionnaire rated the 
spiritual condition of the church at 3 and the fellowship at 4. In order to strengthen the spiritual condition of the church the pastor encourages his members to emphasize prayer. Midweek evening prayer meetings are held in the church.

Another important aspect of spiritual growth is a strong emphasis on music in worship. This church uses both Western and Eastern music. The pastor says that God is praised by singing hymns.

One of the major activities used by this church to keep the church lively is its visitation program. Visiting regular members, newly baptized members, and inactive members is strongly emphasized. The church ladies in the women's association, Mahila Mandal, visit homes to pray and to encourage warmth and fellowship among the laity. The pastor also visits new members regularly and strongly emphasizes praying with them.

Measures taken to activate the inactive are visits by members and the pastor, praying with them and encouraging them to rejoin fellowship. Five percent of the members are totally inactive and do not attend church.

When asked about future plans of this church, leaders mentioned more evangelistic meetings and maintaining a 
strong outreach programs.

\section{Evaluation}

The Bethel Savior's Alliance Church follows several generally accepted church-growth principles:

1. Having the same pastor for many years

2. Prayer meetings which encourage fellowship and spiritual nurture

3. A high percentage of giving to the church

4. Awareness of the importance in India of having women active in ministry and visitation

5. A strong emphasis on home visitation.

When highlights of this church are viewed, the emphasis placed on evangelism is noteworthy. At the same time it should be noted that tract distribution and home visitation by themselves are not enough. More lay people should be well equipped and sent out for ministries according to their spiritual gifts and skills. The large amount of evangelistic work in the city and in the surrounding villages, together with a high percentage of tithe payers, indicates that the laity of the church are willing to support the church plans and programs.

Although there is significant emphasis on evangelism 
and fellowship, the growth of the church is still quite low. The decadal growth rate (DGR) for the nine-year period from 1991 to 1999 was only 2.2 percent, which is very poor growth.

Summarizing the key church-growth principles that have helped these churches grow are (1) the longevity of the pastor serving the church; (2) emphasis on spiritual growth programs such as worship, prayer, music, and fellowship; (3) following research-based evangelistic and church-planting programs and emphasizing lay involvement; and (4) complete trust and dependence on the power and working of the Holy Spirit.

The following chapter presents a description and analysis of the growth patterns of the Kolhapur SDA church. 
CHAPTER 4

THE KOLHAPUR CHURCH

\section{The setting of the Kolhapur Church}

The Kolhapur Church can be better understood in its cultural, religious, and historical setting. A brief history of the Kolhapur Church will help the reader to understand the growth of the church.

\section{General Information}

The city of Kolhapur is situated in the southwestern part of Maharashtra, in the Sahyadri mountain range, on the banks of the Panchaganga River. This city is surrounded on all sides by rivers. To the east are the Krishna and Ganik, to the west are the Shiva and Mayuri. To the south are the Veda and Yaksha. And to the north are the Krishna and Warna. ${ }^{1}$ The name Kolhapur is derived from these geographical features. It originated from the Kannada word (neighboring state of Karnataka) kolla or golla, meaning

${ }^{1}$ Prasad P. Topne, "A Brief History of the Holy City of Kolhapur," in Tourist Guide in View of Kolhapur (Pune: Scenery Publication, 1997), 23. 
"river bed." 1

Kolhapur covers 66.82 square kilometers. The city is situated at 16.41 degrees latitude north and 74.17 degrees longitude east. It is 1,790 feet above sea level. ${ }^{2}$

The climate of Kolhapur is temperate. In the months of March to May, it is hot, but the maximum temperature never exceeds 38 degrees Celsius. The rainy season is from June to October. Cold weather is from November to February when the temperature is from 14 to 16 degrees Celsius. ${ }^{3}$

\section{History}

In Hindu mythology, Kolhapur is called Karvir, which means the city lifted up by the hands of the goddess Mahalaxmi. ${ }^{4}$ The city has a long historical tradition and has been a center of religious and political power and trade. This is witnessed by the many existing carvings, remains of temples, and other historical buildings. ${ }^{5}$

${ }^{1}$ District Census Handbook: Kolhapur (Mumbai : Government Printing and Stationery, Maharashtra State, 1991), 14.

${ }^{2}$ Santhosh Khatavkar, Karvir Darshan (Kolhapur: Sukh Dham, 1998), 2 .

${ }^{3}$ District Census Handbook: Kol hapur, 7 .

${ }^{4}$ Nandkumar Marathe, Kolhapur Darshan (Sangli: Gokhale Granth Prakashan, 1998), 9.

${ }^{5}$ Topne, 23. 
The history of Kolhapur is traced back to the pre-Aryan period, before the fifteenth century B.C. This is evident from the centrally located old temple "of the god of nonAryans" and the Harijans (low caste, original inhabitants, known as "people of god") residing around it. Also there are additional evidences from excavations and old literature. ${ }^{1}$ Evidence shows that this very rich city was destroyed in the eighth and ninth centuries A.D. by earthquakes. ${ }^{2}$

The history of Kolhapur is divided into three periods: the Hindu period up to 1347, the Muslim period from 1347 to 1700, and the Maratha period from 1700 onwards. During the British period Kolhapur remained a separate state ruled by honorary, petty kings. ${ }^{3}$

'Marathe 6-8.

${ }^{2}$ Topne, 23.

${ }^{3}$ District Census Handbook: Kolhapur, 14 . 
The People

The population of Kolhapur, according to the 1991 census, was $406,370 .^{1}$ of this number, people from the tribes were only $674 .^{2}$ The people of Kolhapur are of medium height. Their skin color is brown. Their staple food is rice, bhakari (unleavened, round, thin, flat bread made from millet flour and baked in a hot iron pan), curry to mix with the rice, and vegetables. A typical Kolhapur person wears a turban, a long loose shirt, and a dhoti around his waist and thighs. Women wear a sari and blouse. Eighty-five percent of the inhabitants speak Marathi; 3 percent speak Kannada; other languages are Urdu, Sindhi, and languages from neighboring states. The occupation of people is mainly farming, but many are engaged in industrial jobs. People are kind and respectful to others, and respect for guests is highly valued.

Among sports, wrestling is famous in Kolhapur, with some of the noted Indian wrestlers coming from this place. The famous wrestling stadium (Khas Baugh Maidan) was built in 1894 by King Shahu Maharaj; it accommodates 20,000

\footnotetext{
IIbid., 22 .

${ }^{2}$ Ibid., 321
} 
persons. ${ }^{1}$ Periodically, wrestling matches on a national level are arranged at this place. ${ }^{2}$

\section{Economy}

The economy of Kolhapur is mainly agricultural and industrial. This city is known for cooperative movements such as cooperative sugar mills, milk projects, and industrial units. Sugar cane is grown on a large scale, and there is high production of jaggery (brown sugar) and sugar. Leather goods, especially footwear called Kolhapuri chappals (sandals), are known all over India. ${ }^{3}$

Kolhapur carries on a lively export-import business; the most important commodities imported are machinery parts, cloth, and medicines. The most important commodities exported are engines that run on oil and spare parts, jaggery, and sugar.

In 1993 there were fifty-five banks. There were five agricultural credit societies and 564 nonagricultural credit societies. ${ }^{4}$

'Marathe, 32 .

${ }^{2}$ Ibid. , 56

${ }^{3}$ Ibid. , 57 .

${ }^{4}$ District Census Hand Book: Kolhapur, 309. 
In three major industrial areas, various industries are growing fast. One of the major and oldest industrial areas is Udyamnagar, in the heart of the city. In 1991 there were 480 industries and factories, of which 214 were related to various machines. ${ }^{1}$

Recently developed areas are Shiroli and Gokulshirgaon, where there are 10,000 small-and large-scale industries. ${ }^{2}$ The Shiroli Maharashtra Industrial Development Corporation is situated on 269 hectares. Funds invested in it are Rs.729,800,000, and the number of workers in 1993 was $9,130 \cdot \cdot^{3}$

\section{Education}

Kolhapur is well advanced in the educational field. The literacy rate is 82.71 percent. ${ }^{4}$ There are six general colleges, four medical schools, and three engineering colleges. There are 68 junior colleges/higher secondary and

${ }^{1}$ B. B. Mulik, "Shiroli Audhogic Vasahatichi Ghoddaud," in Rajashri Shahu Mahotsav 1993, ed. R. K. Kunberkar (Kolhapur: Rajashri Shahu Chatrapati Memorial Trust, 1993), 94.

${ }^{2}$ Samrat Fadnis, "Kolhapurchya Audhogic Vishwachi Safar: Udyamnagar," Musafir, January-March 1994, 17.

${ }^{3}$ Mulik, 94 .

${ }^{4}$ District Census Handbook: Kolhapur, 34 . 
middle schools, 63 secondary schools and 158 primary schools. ${ }^{1}$

Shivaji University was established in 1963 ; it is one of the four major universities in the state and the pride of Kolhapur. It has an attractive historical building and a statue of king Shivaji, after whom the university is named, stands in front of the main building. Every year approximately 125,000 students pursue higher studies there. ${ }^{2}$ In the educational, social, and economic revolution of this city, the seeds were sown and developed by king Chatrapati Shahu Maharaj, who ruled from 1894 to 1922 , during British reign, as an honorary dominion king. He emphasized free and compulsory primary education for all, especially the lower, outcaste classes, and introduced education for women. He started many student hostels without any caste distinctions. Agricultural, industrial, and technical education was started. The king advocated the idea of a secular government. He strongly opposed the harassment of lower classes by the higher strata of society, especially the Brahmins. This king is still today highly reverenced and loved by the people of Kolhapur. He is

\footnotetext{
${ }^{1}$ Ibid., 308

${ }^{2}$ Marathe, 36.
} 
called the father of the green revolution and of cooperative movements in various fields. ${ }^{1}$

\section{Religion}

The major religion of this city is Hinduism. There are also Muslims and Christians and other minor religious groups. People of this city are viewed as very religious and many noted temples are found here.

The Mahalaxmi temple in the heart of the city is a source of pride for the city. It was built in A.D. 800 . It contains many stone pillars with marvelous carvings on them. On the same premises there are thirty-five temples of other gods and goddesses. Worship is offered daily and a yearly great worship (mahapuja) is a major attraction of the state. All the temples in the city, great and small, number $3,000 .^{2}$ Tembalabai is another temple on a small hill on the western side of the city. It is the temple of the goddess Trambuli, who is worshipped by thousands. ${ }^{3}$ The famous Shankaracharya Muth, a place of meditation, was built in the

${ }^{1}$ Rajashri Shahu Chatrapati Smarak Bhavan Udghatan Samarambh (Kolhapur: Rajashri Shahu Chhatrapati Memorial Trust, 1981), 77-80.

$$
\begin{aligned}
& { }^{2} \text { Marathe, } 16 . \\
& { }^{3} \text { Ibid., 36-37. }
\end{aligned}
$$


thirteenth century by one of the head priests of Hinduism. ${ }^{1}$ Kolhapur is called Dakshin Kashi, the center of Hindu worship in the southern part of India.

All the major Hindu festivals are celebrated in this city. Gudi Padva is celebrated at the beginning of the Hindu new year. Farmers celebrate Bendur in appreciation of the hard work done by the bullocks. Nagpanchami (snake worship) is celebrated very enthusiastically. ${ }^{2}$

\section{A Brief History of the Kolhapur SDA Church}

\section{Early History}

The earliest history of the Kolhapur SDA church can be traced to the period between 1919 and 1925. A dedicated servant of God, S. O. Martin, sailed from San Francisco, via Japan, during World War I and reached Bombay on December 25, 1916. After laboring with the Church of Christ for three years, he came across the Sabbath question when he read a book sold on a train by an Indian colporteur. After thorough study with an Adventist missionary he accepted Adventism in July 1919. After his furlough in 1925 he labored for the Seventh-day Adventist Church. of his work

${ }^{1}$ Ibid., 11 .

${ }^{2}$ District Census Handbook: Kolhapur, 57. 
he wrote, "In the leading of God we opened a new mission station in the native state of Kolhapur. As the work developed, different Indian workers were assigned to help carry forward the work."1

Martin worked at the newly established mission at Kolhapur with S. S. Pandit Jr., who had just graduated from Spicer College. In their first year of labor, forty-seven people were baptized and brought into the church. At the same time, there were over six hundred believers in the Kolhapur district. ${ }^{2}$

The church membership record books give November 23, 1929, as the date for the organization of the Kolhapur SDA Church. It was rededicated in 1945 by S. B. Gaikwad, then pastor and district leader of Kolhapur.

The earliest pioneer workers labored with a spirit of great enthusiasm. As the result of their effort a group of believers regularly gathered for prayer. By 1951, the head office for the work in South Maharashtra was situated in Hatkalangle, 24 kilometers east of Kolhạpur, and M. L. Gaikwad pastored the church at Kolhapur. Later the district

${ }^{1}$ S. O. Martin, 15,000 Miles to the Truth (Nashville: Southern Publishing, 1961), 20-29, 112-120, 127.

${ }^{2}$ Ibid. 
office was shifted from Hatkalangle to Kolhapur. Then in 1952, M. D. Moses was appointed district leader and pastor at the headquarters at Kolhapur, where he worked with his associate pastor, D. D. Kale.

The head office at Kolhapur was situated in a rented bungalow called "Ebenezer's Cottage," in the New Shahupuri area until 1966. Popularly known as Baker's Bungalow, it was the residence of Adventist pastors and the place for church meetings. In 1965, S. B. Shinde was transferred to Kolhapur to pastor this church. Soon a tin shed was built nearby; there members began having their worship. After much prayer and hard work, a plot of land was purchased in Shivaji Park, one-half km from Ebenezer's Cottage, for Rs. 53,000. In 1970, an attractive church was built for the forty-two believers who met regularly for prayer and worship.

\section{Pastors and Evangelistic Programs}

The pastors who served the Kolhapur Church could be classified into the following two periods, according to the characteristics of their work and the methods that were emphasized. The information gathered is from the old correspondence and interviews with the past pastors. 


\section{First Period}

The first period, from 1925 to 1948, was the missionary period. The work was largely missionary in nature. Large tent meetings lasting for three months, group Bible study, emphasis on enrollment in the Voice of Prophecy (VOP), lessons, and personal and deep concern for people were the main evangelistic methods of this period. Every year a lay congress (Lay Mela) for three weeks gave opportunity to the members in all the churches to gather for celebration, fellowship, and spiritual nourishment. The following missionaries and local workers served during this period.

S. O. Martin (1925-1937): His major achievement was that in 1933 he acquired five acres of centrally located land at Hatkalangle, for mission work in Kolhapur. It was donated by the Maharaja (king) of Kolhapur. Here he established the head office for the work in south Maharastra. Mekhshamji Jadhav pastored this church under Martin's guidance.

W. H. MCHenry $(1938-1940)$ : His major achievement was deep and personal concern for the needy and poor. People in the area respected him and lovingly called him Papa McHenry. Sahadev Pandit was the local pastor of Kolhapur under McHenry. 
W. H. Joarden (1942-1948): His major achievement was the beginning of the Marathi Voice of Prophecy School. Sahavdev Pandit continued to work with him.

\section{Second Period}

The second period, since 1948, is of Indian leaders working as district directors, supervisng the work in the Kolhapur area and pastoring the Kolhapur church. The first twenty years of this period were characterized by blending missionary and local methods. The period since 1970 has been characterized by evangelistic methods that are more personal, such as visiting homes of members, holding cottage meetings, and giving Bible studies. There has also been more concentration on outreach to neighboring villages. The leaders during this period have been:

V.P. Muthia (1948 to 1950): Even though Muthia came from Tamil Nadu, he learned the Marathi language in order to reach the common people. He spoke with people in their own language, and sang and taught Marathi hymns with great enthusiasm.

M. D. Moses (1952 to 1953): He was born in Andhra Pradesh and also learned the common Marathi language. He prayed with people and taught the word of God in Marathi and 
sang and taught Marathi hymns.

S. L. Khandagle (1954 to 1957): Keeping closely in touch with the people was his primary evangelistic method.

S. B. Gaikwad (1958 to 1959): He edited the Marathi translation of Counsel to Churches from the English version, and the Baptismal Manual that is still in use.

D. P. Kate (1960 to 1961): Teaching truth in a commanding base voice was his basic characteristic.

V. D. Ohal (1962 to 1964): Personal visitation programs and systematic Bible study were characteristic of his evangelistic methods.

S. B. Shinde (1965 to 1972): Shinde systematically planned church programs. He gave importance to strengthening his personal spiritual life and that of his family members.

M. L. Gaikwad (1972 to 1974): This humble pastor was highly dedicated and very sincere in his work. He was a God-fearing man.

M. D. Gaikwad (1974 to 1976): He mingled with people and was one with them in their sorrows and happiness.

S. S. Pandit (1976 to 1980): He was very particular in regularly visiting the members and praying with them. Vijay Dhumal and then Vijay Gaikwad were associated with Pandit, 
adding to his strength.

U. R. Anandrao (1980 to 1981): I was associate pastor under him. Our teamwork in conducting cottage meetings in neighboring places, namely Shingnapur and Chokak, helped the church gain strength.

V. J. Khandagle (1981 to 1987): He was friendly and participated in various activities of the believers, as well as of the surrounding community.

T. B. Kakade served this church from 1988 to 1991. He too had a deep personal relation with members. He emphasized visiting homes and praying with people. These were his evangelistics methods.

S. M. Salve has been the pastor of this church since 1992. He has stressed home visitation. He has made contacts with non-Christian young people and has reached a higher level of persons than is usual in the church. With the help of laity, he has also reached out to the suburbs of the city and neighboring villages. Of the five companies, two were established by this pastor: at Halondi with sixteen members and at Kotholi with seventeen members. Kotholi is 31 kilometers from Kolhapur, between the Sahyadri Ranges. Reaching this area is challenging. 
Major Events in the Church

Major events in this church have been large-scale public evangelistic meetings, either in the church or on open grounds in the city. Information gathered on these is from old correspondence and interviews with former pastors. In 1949, C. A. W. Ritchie conducted a "most excellent meeting," at which eleven workers from the Kolhapur area were called to help. Daily attendance was between 700 and 800. One hundred forty persons were enrolled in the VOP School. ${ }^{1}$ Ritchie further states: "The cards reveal several doctors, lawyers, educationalists, and pastors of other churches." ${ }^{2}$ A former Prime Minister of the state is also reported to have attended these meetings.

In 1953, M. D. Moses conducted a major evangelistic meeting on a public ground, near the present state Transport Stand. The attendance was 800 people every night. The number of people baptized is not traceable, but the meetings made a strong impact on the minds of older members.

In 1975, a church school was started by Rajan K. Dass, with only one class for nursery students, in the church

${ }^{1}$ C. W. A. Ritchie to F. E. Spiess, President of Western India Union, July 2, 1949, Office of the Executive Secretary, Mahashtra section of SDA.

${ }^{2}$ Ibid. 
vestry at Shivaji Park. He worked for one year looking after both school and church. Later Mrs. S. S. Pandit became the teacher and further developed this school. Today, a three-storey school building stands, with the original church hall as a part of it. The enrollment in this school was "943 in the 1994-95 school year; 1,030 in 1995-96; 1,106 in $1996-97 ; 1,123$ in $1997-98 ; 1,290$ in 1998-99; and 1,295 in 1999-2000. The results of the Indian Certificate of Secondary Education Exam were 96 percent in 1999 and 98 percent in 2000. This is one of the outstanding schools in the city. The school helps the church by maintaining the church hall and supporting church programs financially. At the same time, issues such as proper church programs and use of church property have caused ill feelings between school and church authorities. This has affected the unity and spirit in the church.

In 1988, R. D. Riches, then president of the Central India Union, conducted a ten-day evangelistic series in the church. There was good response from the public. The average attendance was about 100 people. Ten people were baptized and there was much awakening in the church.

Very soon, J. Willmot, Ministerial Director for the Southern Asia Division, conducted a major evangelistic 
meeting in the heart of the city on the Airwin High school grounds. Daily attendance was between 500 and 700 persons. His sermons were highly spiritual and very emotional. Twenty-five people received baptism and there was a revival in the church.

In 1995 R. S. Shinge, former president of the Central India Union, conducted a series of evangelistic meetings in the city. The deep study of Bible topics and doctrinal teachings was emphasized. "Knowing the True God" was the theme of these meetings. The average daily attendance was 100 persons from various Christian denominations. Seven persons were baptized.

In 1997, a national convention was organized by the African Adventist Student Association of Shivaji University, Kolhapur. Some 200 student representatives from all over the country gathered for spiritual fellowship. The emphasis was that all of them should be more active and effective in their respective churches to help their churches grow.

\section{The Surveys}

This section of the chapter reports the results of three questionnaires. One was given to ten active church members; another was filled out by ten inactive church 
members; and the third was answered by the eight pastors who have served the Kolhapur church during the last twenty-eight years. The ten active members were chosen especially because they had expressed their concern for change in the church. All three surveys are found in appendix B. The ratings given by the respondents are presented in terms of percentages. Respondents were asked to rate different aspects of religious experience and practice on a percentage scale. This was done because the people of Maharashtra are used to this way of expressing themselves.

\section{Active Members}

The following information was gathered from ten active members in the Kolhapur Church. Table 1 shows the age of the ten active members responding to this survey. Four were between 20 and 35 years of age; 2 were between 36 and $50 ; 3$ were between 51 and 64 years of age; and 1 was over 65 . Table 2 shows the length of time the members had been in the church. One had been a member less than 1 year; 3 had been in the church between 11 and 20 years; and 6 had been there longer than 20 years. 
TABLE 1

AGE OF RESPONDENTS

\begin{tabular}{lc}
\hline \multicolumn{1}{c}{ Age Group } & Number of persons \\
\hline 19 years and under & --- \\
$20-35$ years & 4 \\
$36-50$ years & 2 \\
$51-65$ years & 3 \\
66 and above & 1 \\
\hline Total & 10 \\
\hline
\end{tabular}

TABLE 2

LENGTH OF MEMBERSHIP IN THE CHURCH

Length of Membership Number of years

Less than 1 year

1

11 to 20 years 3

Over 20 years 6

Total 10

Table 3 shows the church offices held by the respondents. Only one was currently not holding an office. Eight were currently elders, deacons or deaconesses, or Sabbath School leaders. 
TABLE 3

POSITIONS HELD IN THE CHURCH

\begin{tabular}{lcc}
\hline Positions & Now & Before \\
\hline Elders & 3 & 2 \\
Deacon/Deaconess/Treasurer & 3 & 4 \\
Sabbath School Leaders & 2 & 2 \\
Janitorial Work & 1 & 0 \\
None & 1 & 2 \\
\hline Total & 10 & 10 \\
\hline
\end{tabular}

\section{Spiritual Life}

Those surveyed were asked questions about their spiritual life and church activities. Table 4 lists their responses, expressed in percentages. When asked about their personal relationship with Jesus Christ, the average response was 82 percent, with 4 persons rating their relation at 100 percent. Exactly the same responses were given to the second question about their personal assurance of eternal life. Personal prayer also received 82 percent. Tithing faithfully was rated at 79 percent.

Only one person rated attending Sabbath School on time and regularly with a 100 percent; the average was 63 percent. Personal Bible study received a lower score (45 percent), with no one claiming 100 percent and 3 reporting 10 percent or less. Witnessing in everyday life received an 
average rating of 42 , while having family worship had the lowest rating, with only 35 percent.

TABLE 4

SPIRITUAL LIFE AND INVOLVEMENT IN CHURCH ACTIVITIES

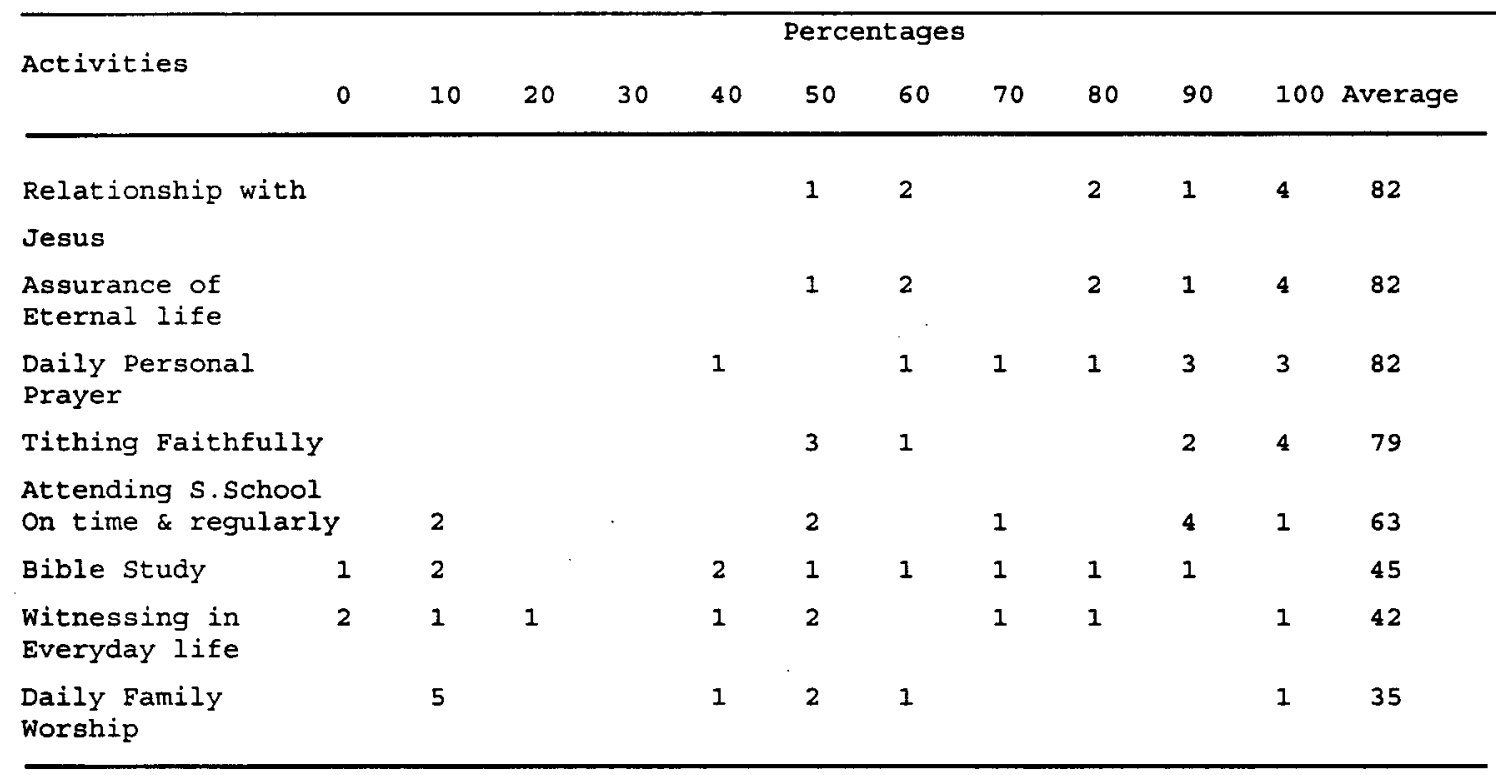

The participants in the survey were asked to rate each of eight resources helpful in strengthening their spiritual life and Christian experience. The results appear in table 5. The highest marks were obtained by the Sabbath School program and lesson study, with 65 percent each. Sermons were rated at 57 percent, while pastoral care and church services were rated at 56 percent. Music in the church (36 percent) and Adventist literature (33 percent) were 
considered the least helpful resources for strengthening spiritual life.

TABLE 5

RESOURCES FOR STRENGTHENING SPIRITUAL LIFE

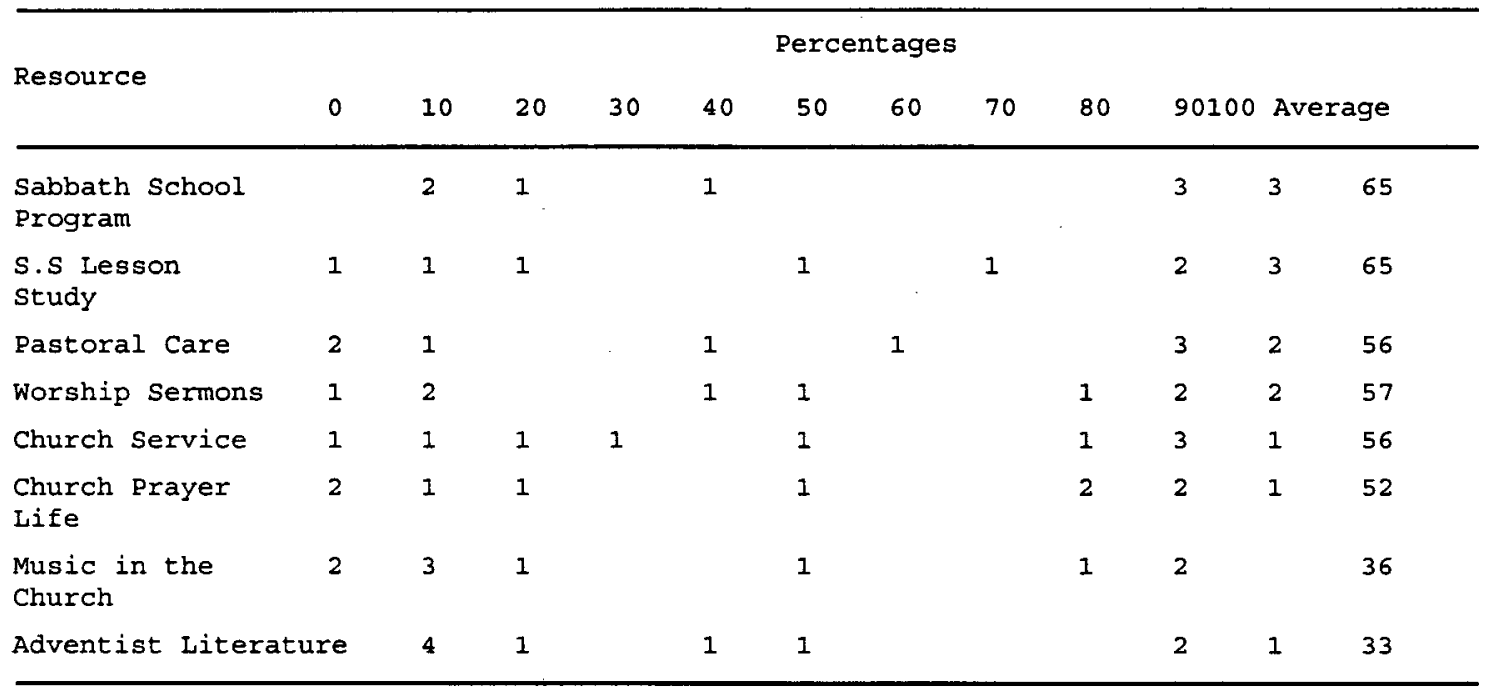

Table 6 shows the members' engagement in different types of soul-winning activities. The ten participants in the survey were asked to circle a percentage to indicate how well prepared they felt for the work of soul winning; the average was 27 percent. Asked about winning non-Adventist relatives and friends, the rating was higher (43 percent).

\section{Church Activities and Emphases}

The active members who participated in the survey were 
asked to show their evaluation of different church emphases. Respondents felt that the church placed its greatest emphasis on standards (57 percent). The care of new members was rated at 41 percent. Even lower marks were given to music (40 percent), spiritual liveliness (38 percent), and member retention (37 percent). The lowest scores were given to following the church manual (34 percent), and the church soul-winning program (32 percent). These results are shown in table 7 .

TABLE 6

ENGAGEMENT IN SOUL WINNING

\begin{tabular}{|c|c|c|c|c|c|c|c|c|c|c|c|c|}
\hline \multirow[t]{2}{*}{ Activity } & \multirow[b]{2}{*}{0} & \multirow[b]{2}{*}{10} & \multirow[b]{2}{*}{20} & \multirow[b]{2}{*}{30} & \multirow[b]{2}{*}{40} & \multicolumn{3}{|c|}{ Percentages } & \multirow[b]{2}{*}{80} & \multirow[b]{2}{*}{90} & \multirow[b]{2}{*}{100} & \multirow[b]{2}{*}{ Average } \\
\hline & & & & & & 50 & 60 & 70 & & & & \\
\hline $\begin{array}{l}\text { Preparation for } \\
\text { Soul Winning }\end{array}$ & 2 & 1 & 2 & 1 & 1 & 3 & & & & & & 27 \\
\hline $\begin{array}{l}\text { Winning relatives } \\
\text { and friends }\end{array}$ & 2 & & 1 & 1 & 1 & 1 & 1 & 2 & & 1 & & 43 \\
\hline
\end{tabular}

The ten active members who participated in the survey were asked to rate fellowship in the church. Two felt the church was warm and loving like a family, five felt there was a friendly atmosphere and had made some friends, one person felt that people were friendly but could not develop any friendly relationships, and two people said that the 
church was cold and exclusive. Their responses appear in table 8 .

\section{TABLE 7}

CHURCH EMPHASIS

\begin{tabular}{|c|c|c|c|c|c|c|c|c|c|c|c|c|}
\hline \multirow{2}{*}{ Areas } & \multicolumn{12}{|c|}{ Percentages } \\
\hline & 0 & 10 & 20 & 30 & 40 & 50 & 60 & 70 & 80 & 90 & 100 & Average \\
\hline $\begin{array}{l}\text { Level of Adventist } \\
\text { Standard }\end{array}$ & 1 & & 1 & & 1 & 3 & 1 & & & & 3 & 57 \\
\hline $\begin{array}{l}\text { Care \& Involvement } \\
\text { of new members in } \\
\text { Church activities }\end{array}$ & 2 & 2 & 1 & & & 2 & & & 1 & 1 & 1 & 41 \\
\hline Effective Music & 1 & & 1 & 2 & 2 & 2 & & 2 & & & & 40 \\
\hline $\begin{array}{l}\text { Spiritual live- } \\
\text { liness in the Churc }\end{array}$ & $\begin{array}{c}1 \\
\mathrm{ch}\end{array}$ & 1 & 1 & 3 & & 2 & & & 2 & & & 38 \\
\hline $\begin{array}{l}\text { Keeping members } \\
\text { Active in Church }\end{array}$ & 2 & 2 & & 1 & 1 & 2 & & & & 2 & & 37 \\
\hline $\begin{array}{l}\text { Following Church } \\
\text { Manual carefully }\end{array}$ & 1 & 3 & & 3 & & 1 & & & 1 & 1 & & 34 \\
\hline $\begin{array}{l}\text { Soul winning } \\
\text { program }\end{array}$ & 3 & 1 & & 1 & 1 & 2 & & & & 1 & 1 & 32 \\
\hline
\end{tabular}

TABLE 8

FELLOWSHIP IN THE CHURCH

Type of Fellowship Number of members responding

Very warm and loving, like family 2

Friendly atmosphere; I have some friends 5

People are friendly but I have not made 1 many friends

Cold, exclusive; I don't feel at home 2 
The participants in the survey were asked to rate the emphasis placed by the pastor on four different activities. Respondents felt that the greatest emphasis was on the soulwinning program ( 67 percent). Slightly below that was the emphasis on spiritual life (65 percent). Lower scores were given to the emphases on keeping members active (62 percent) and making church plans and programs (54 percent).

TABLE 9

THE PASTOR'S EMPHASIS

\begin{tabular}{|c|c|c|c|c|c|c|c|c|c|c|c|c|}
\hline \multirow{2}{*}{ Emphasis } & \multicolumn{10}{|c|}{ Percentages } & \multicolumn{2}{|l|}{. } \\
\hline & 0 & 10 & 20 & 30 & 40 & 50 & 60 & 70 & 80 & 90 & 100 & Average \\
\hline $\begin{array}{l}\text { Soul Winning } \\
\text { Program }\end{array}$ & & & 1 & 1 & & 3 & & 1 & & & 4 & 67 \\
\hline $\begin{array}{l}\text { Church Spiritual } \\
\text { Life }\end{array}$ & 1 & 1 & 1 & & & 1 & & 1 & & & 5 & 65 \\
\hline $\begin{array}{l}\text { Keeping Members } \\
\text { Active }\end{array}$ & 1 & & & 2 & & 1 & & 1 & 2 & 2 & 1 & 62 \\
\hline $\begin{array}{l}\text { Making Church } \\
\text { Plans \& programs }\end{array}$ & 1 & 1 & & 1 & & 2 & 1 & 1 & 1 & 1 & $I$ & 54 \\
\hline
\end{tabular}

The participants were asked to rate the section (mission) Administration on two items. On concern for the local church, the rating was low (25 percent). On plans and programs for the local church, the rating was higher (43 percent). 
TABLE 10

SECTION ADMINISTRATION EVALUATION

\begin{tabular}{|c|c|c|c|c|c|c|c|c|c|c|c|c|}
\hline \multirow{2}{*}{ Activities } & \multicolumn{9}{|c|}{ Percentages } & \multirow[b]{2}{*}{90} & \multirow[b]{2}{*}{100} & \multirow[b]{2}{*}{ Average } \\
\hline & 0 & 10 & 20 & 30 & 40 & 50 & 60 & 70 & 80 & & & \\
\hline $\begin{array}{l}\text { Concern towards } \\
\text { the Church }\end{array}$ & 5 & 1 & 1 & & & & 1 & 1 & & 1 & & 25 \\
\hline $\begin{array}{l}\text { Plans \& Programs } \\
\text { for the Church }\end{array}$ & 1 & 3 & 1 & & & 1 & & 1 & 1 & 2 & & 43 \\
\hline
\end{tabular}

When asked to mention the areas in which the church was growing, 8 out of 10 responded. Three said the church was growing in membership and in soul winning. Two affirmed that the church was increasing in tithes and offerings. One said the church was not growing in any specific area. When asked to state the areas in which the church was not growing, 7 out of 10 responded. Two people mentioned each of the following areas: lack of growth in lay mobilization, pastor-member relationship, youth programs, and encouragement. One person mentioned each of the following: deficiency in evangelism, fellowship, spiritual life, attendance, and helping the poor and needy.

When asked to state reasons why the church was not growing, 7 responded and gave one or more reasons. Three mentioned that the laity were unwilling to participate in church activities. Two mentions each were made of the 
difficulty between church and school administration, the laity not being mobilized, and insufficient programs for the spiritual development of the church.

When asked to make suggestions for change, 6 responded and gave one or more suggestions. Each of the following were suggested once: teaching new members thoroughly before and after baptism, having more family or group prayer meetings, emphasizing spiritual growth and fellowship, and improving church and school relations. The following were suggested twice: more plans and programs for the youth in the church, and efforts toward making members more active. When asked to state their expectations, 5 of the 10 members made one or more comments as follows:

1. Every member should be involved in the soul-winning program. Each member should meet church appointments promptly and on time, especially the worship service in the church.

2. Better relations should be established between church and school. Teachers should be more active in church affairs and the pastor should be a spiritual guide to both the church and the school.

3. Complete trust, confidence, and co-operation between the members and the church leaders, including the pastor, 
should be developed. The growth of the church should be the aim of the leaders.

4. Marathi and English worship services should be separate.

5. The Section administration should help the church grow spiritually.

\section{Inactive Members}

Table 11 shows the age of the ten inactive members who responded to this survey. One was between 20 and 35 years of age, 6 were between 36 and 50 years, 2 were between 51 and 65 years, and 1 was over 66 .

TABLE 11

AGE OF RESPONDENTS

\begin{tabular}{lc}
\hline Age Group & Number of persons \\
\hline $20-35$ years & 1 \\
$36-50$ years & 6 \\
$51-65$ years & 2 \\
66 and above & 1 \\
\hline Total & 10 \\
\hline
\end{tabular}

Table 12 shows how long the ten inactive individuals had been church members. The largest group ( 8 individuals) 
had been members less than five years. The other two had been members between 6 and 15 years.

TABLE 12

LENGTH OF MEMBERSHIP IN THE CHURCH

\begin{tabular}{lc}
\hline \multicolumn{1}{c}{ Length of Membership } & Number of Persons \\
\hline $1-5$ years & 8 \\
$6-10$ years & 1 \\
$11-15$ years & 1 \\
\hline Total & 10 \\
\hline
\end{tabular}

When asked what attracted them to the Adventist Church, 1 marked appealing church beliefs and 1 noted the warm fellowship of believers. Five noted the conviction of the church pastor; 3 marked friends and relatives in the church. Table 13 shows the relative importance of church resources to strengthen the spiritual life and Christian experience. Only 7 responded. The church service was rated at 61.43 percent, sermons were given 58.57 percent; the Sabbath School lesson study was rated at 51.43 percent; effective music in worship was given 48.57 percent; and Sabbath School programs were given 47.15 percent. Lower ratings were given to pastoral care (42.86 percent) and the prayer life of the 
church (41.43 percent). Adventist literature and plans and programs promoted by Section administration were both rated at 22.86 percent.

TABLE 13

RESOURCES FOR STRENGTHENING SPIRITUAL LIFE

\begin{tabular}{|c|c|c|c|c|c|c|c|c|c|c|c|c|}
\hline \multirow{2}{*}{ Resources } & \multicolumn{10}{|c|}{ Percentages } & \multirow[b]{2}{*}{100} & \multirow[b]{2}{*}{ Average } \\
\hline & 0 & 10 & 20 & 30 & 40 & 50 & 60 & 70 & 80 & 90 & & \\
\hline Church Services & & & & 1 & & 3 & & 1 & 1 & & 1 & 61.43 \\
\hline Sermons & & 1 & & 1 & & 1 & & 2 & 1 & & 1 & 58.57 \\
\hline $\begin{array}{l}\text { S. School Lesson } \\
\text { Study }\end{array}$ & & & 2 & 1 & & & 2 & 1 & & & 1 & 51.43 \\
\hline $\begin{array}{l}\text { Music in } \\
\text { Worship }\end{array}$ & & & 1 & 1 & 3 & & & 1 & & & 1 & 48.57 \\
\hline S. School Program & & & 1 & 1 & 1 & 2 & 1 & & 1 & & & 47.15 \\
\hline Pastoral Care & 1 & & 2 & & 2 & & & & & 2 & & 42.86 \\
\hline $\begin{array}{l}\text { Prayer life of the } \\
\text { Church }\end{array}$ & & 1 & & 2 & 3 & & & & & & 1 & 41.43 \\
\hline $\begin{array}{l}\text { Adventist } \\
\text { literature }\end{array}$ & 4 & 1 & & & & 1 & & & & & 1 & 22.86 \\
\hline $\begin{array}{l}\text { Plans \& programs } \\
\text { promoted by Section } \\
\text { Administration }\end{array}$ & & 3 & 1 & & & 1 & 1 & & & & & 22.86 \\
\hline
\end{tabular}

When asked how important each of the following factors was in their decision to stop attending church, only 7 responded. The reasons given were lack of fellowship (71.43 percent); mistreatment by members (45.71 percent); worship and other programs not meeting spiritual needs $(38.57$ percent); precepts and practices not matching (27.14 percent); standards too strict (4.29 percent); and not 
believing some of the church teachings ( 1.43 percent). No one marked social pressure from non-Adventists as a reason for discontinuing church attendance. See table 14 .

TABLE 14

REASONS FOR STOPPING CHURCH ATTENDANCE

$=$

\begin{tabular}{|c|c|c|c|c|c|c|c|c|c|c|c|c|}
\hline \multirow{2}{*}{ Reasons } & \multicolumn{10}{|c|}{ Percentages } & \multirow[b]{2}{*}{100} & \multirow[b]{2}{*}{ Average } \\
\hline & 0 & 10 & 20 & 30 & 40 & 50 & 60 & 70 & 80 & 90 & & \\
\hline Lack of Fellowship & & 1 & & & 1 & & 1 & & & 1 & 3 & 71.43 \\
\hline $\begin{array}{l}\text { Mistreatment by } \\
\text { Members }\end{array}$ & 2 & 1 & & & & 1 & & & 1 & 2 & & 45.71 \\
\hline $\begin{array}{l}\text { Unmet Spiritual } \\
\text { needs }\end{array}$ & 2 & & & & 1 & 1 & 3 & & & & & 38.57 \\
\hline $\begin{array}{l}\text { Precepts and } \\
\text { Practices not } \\
\text { matching }\end{array}$ & 3 & & 2 & & & & 1 & & & 1 & & 27.14 \\
\hline $\begin{array}{l}\text { Standards too } \\
\text { strict }\end{array}$ & 4 & 3 & & & & & & & & & & 4.29 \\
\hline $\begin{array}{l}\text { Not believing some } \\
\text { of the Church } \\
\text { teachings }\end{array}$ & 6 & 1 & & & & & & & & & & 1.43 \\
\hline $\begin{array}{l}\text { Social pressure fr } \\
\text { non-Adventists }\end{array}$ & & 7 & & & & & & & & & & 0 \\
\hline
\end{tabular}

When asked the reasons for stopping church attendance, 5 said that the church was too far and the worship time was not suitable; 2 mentioned that they did not feel a spiritual atmosphere in the church and were interested in spiritfilled groups such as the New Life Fellowship that conducts prayer meetings in their area. One gave the reason that there was no complete worship service in Marathi; another noted the lack of fellowship with the members; and one 
pointed to a poor relationship with the pastor.

When asked what changes needed to be made before they would again become active church members, 5 wanted more attention paid to spiritual and personal needs of the members; 2 desired that concern for each other and fellowship among believers should grow. One mentioned that worship in Marathi should be conducted separately and be more spiritual. One desired to see revival in the church, and two mentioned the need to start house churches.

When asked about changes expected in the pastor, 5 mentioned regular visitation of members and meeting their spiritual needs. Three mentioned encouraging more prayers and working to encourage more fellowship among believers. Two mentioned paying more attention to the spiritual growth of the church.

When asked about the change they expected from section administration, 9 responded. Six noted that more attention should be given to members in their spiritual and personal needs. One stated that they should bring about revival among the members. Another affirmed that section leaders should guide and advise the pastor. One more pointed out that they should start house churches.

When asked to make suggestions for the church to grow 
spiritually and numerically, 8 responded. Three mentioned that more attention should be paid to the members' spiritual and personal needs, especially those of newly baptized members to help them grow spiritually. Another 3 said that spirit-filled prayer meetings should be conducted in the community, like those of the "New Life Fellowship." One stated that more evangelism should be planned by the church. Another stated that revival in the church should be brought about and the spiritual condition should be improved.

\section{Former Pastors}

Ten pastors have served this church during the past twenty-eight years. Of these, seven were senior pastors and three associate pastors. Of this group, six senior pastors and two associate pastors were surveyed. The length of their pastorate averaged 3.9 years. Six had served between two and four years, while only one had stayed ten years.

The most effective programs of the 1970s were, in order of importance: regular visitation (3 mentions), group Bible study (2 mentions), meeting the spiritual and personal needs of the members ( 2 mentions), prayer in members' houses, and evangelistic meetings (1 mention each).

In the 1980s, the most effective programs were 
conducting cottage meetings ( 3 mentions), regular visitation, Bible study in groups, and community activities (2 mentions each). Fellowship and the use of laity were only mentioned once.

According to the present pastor, the most effective programs have been outreach programs with selected lay people in seven villages, the visitation program, cottage meetings, and group prayer meetings especially for newly baptized members.

The suggestions made by the seven past pastors to the present pastor are as follows:

1. Emphasize effective preaching and teaching.

2. Learn more effective methods of Bible study and evangelism.

3. Have a thorough knowledge of the Bible and pray without ceasing.

4. Develop and use laity effectively.

5. Nurture members spiritually and meet their needs and problems.

The suggestions made by all eight pastors to the present section administration were:

1. Make more visits to the church and implement definite plans and programs. 
2. Keep in close touch with members and pastor for guidance and encouragement.

3. Display a balanced concern for the church's spiritual and numerical growth.

The pastors were asked what they would do if they would again pastor this church. They responded as follows:

1. Develop various plans for the spiritual growth of the church.

2. Do more visiting; form prayer groups and meet members' needs.

3. Do more evangelism and outreach programs.

4. Adopt new methods and plans suitable to the local situation and time.

\section{Church Growth at Kolhapur}

\section{Church Records}

The records of the Kolhapur Church are very poor. The records for Sabbath School programs, major meetings and events of the church, and the church board actions have not been maintained on a regular basis. Before 1980 pastors were more systematic in keeping records, yet the records are not perfect. S. B. Shinde (1965-1972) was very particular in maintaining the church records, especially the church 
board minutes and records of other church events. These are still available in the church-membership record book. V. J. Khandagle (1981-1987) also maintained considerably good records. However, reports sent to the section office are not complete.

The data gathered are from fragmentary records of the church, such as Sabbath School program record books, church membership record books, and church board minutes. Most of the information was collected from the quarterly statistical reports sent by the pastors to the executive secretary of the section office and the quarterly reports to Sabbath School and personal ministry departments.

The statistical data presented are for the period of eight years from 1992 through 1999. The data are incomplete for this church because of irregular reporting by the pastors and because the head office moved three times, losing records in the process.

Table 15 shows the statistical records of the Kolhapur Church from 1992 to 1999, for eight years. 
TABLE 15

STATISTICAL RECORD OF KOLHAPUR CHURCH, 1992-1999

\begin{tabular}{|c|c|c|c|c|c|c|c|c|}
\hline & 92 & 93 & 94 & 95 & 96 & 97 & 98 & 99 \\
\hline Total Membership & 118 & 133 & 138 & 133 & 159 & 201 & 227 & 258 \\
\hline Church Attendance & 20 & & & 20 & 73 & 120 & 140 & 150 \\
\hline $\begin{array}{l}\text { S. School. } \\
\text { Attendance }\end{array}$ & 60 & 80 & 70 & 60 & 73 & 80 & 90 & 96 \\
\hline $\begin{array}{l}\text { Composite } \\
\text { Membership }\end{array}$ & 66 & 106.5 & 104 & 71 & 101.67 & 133.6 & 152.34 & 168 \\
\hline $\begin{array}{l}\text { World baptisms } \\
\text { Members' children' baptisms }\end{array}$ & 14 & 10 & 7 & 3 & 23 & 21 & 29 & 31 \\
\hline Transfer in & 2 & 0 & 0 & 0 & 0 & 0 & 0 & 0 \\
\hline Deaths & 1 & 1 & 0 & 0 & 0 & 0 & 0 & 0 \\
\hline Members dropped & 4 & 12 & 0 & 0 & 0 & 1 & 3 & 0 \\
\hline
\end{tabular}

Kolhapur Church is the main church in south Maharashtra in a cluster of eight churches in the same district within a range of 34 kilometers. An additional church in Miraj is in the neighboring district of Sangli, 51 kilometers from Kolhapur.

Though the church has a long history of seventy-five years, during which outstanding personalities have labored there, and has been the headquarters for missionary activities, the membership growth has been poor. Between 1919 and 1925 the pioneering missionary and local pastor baptized 47. Shinde reports that in 1951 only three families (about 12 members) were attending. He further states that by 1970, 42 believers gathered for prayer in a 
newly constructed church building.

Figure 1 shows baptized members in the church over a period of eight years, 1992-1999; the fluctuation is slight: 118 members at the lowest point and 258 members at the highest point, with a difference of only 140 members.

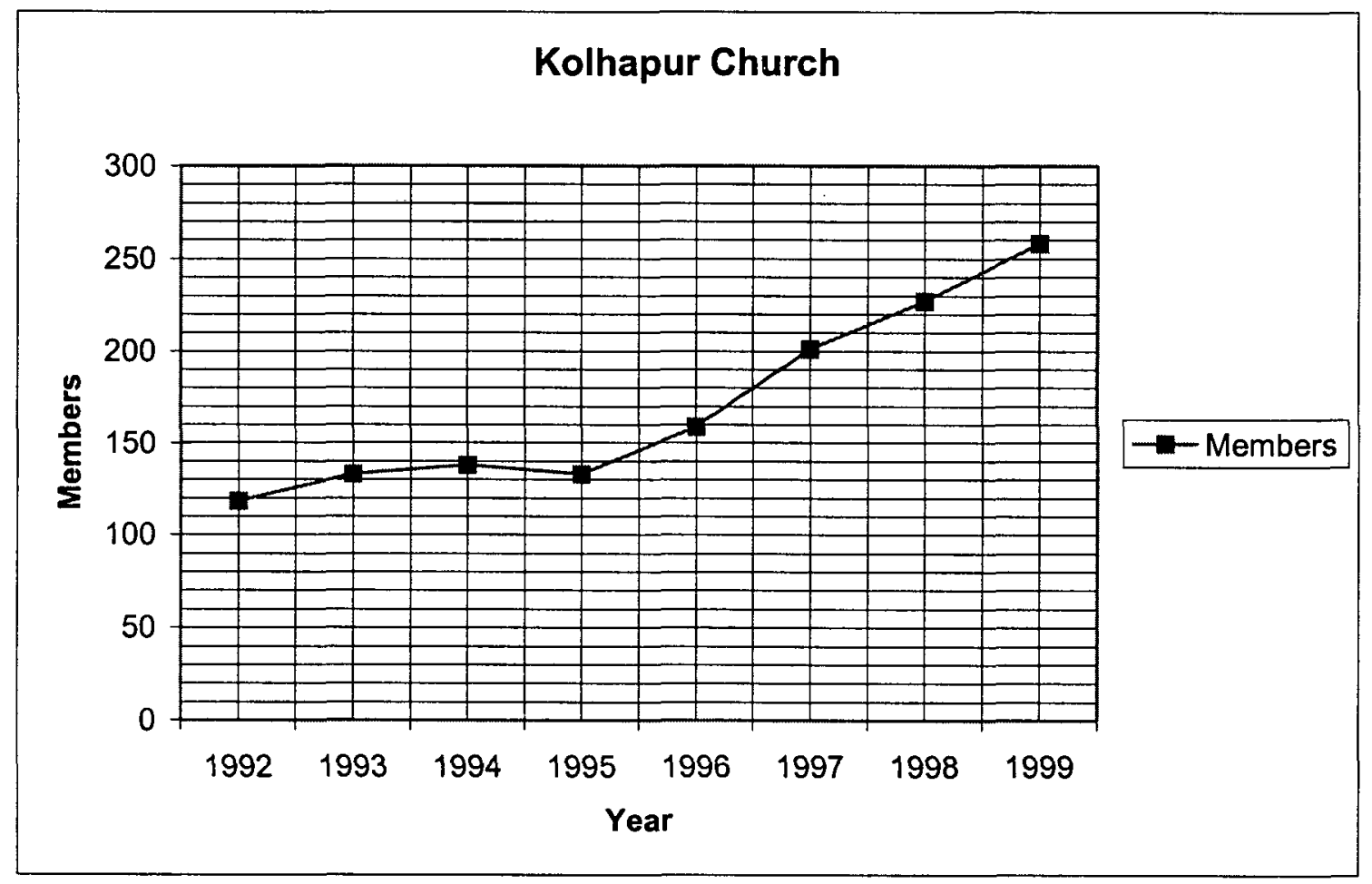

Figure 1. Membership of Kolhapur Church 1992-1999.

Figure 2, for composite membership (the sum of church members, Sabbath School members, and church attendance divided by 3 ), shows 66 as the lowest point and 168 as the highest point with a difference of only 102 members. The 
Annual Growth Rate (AGR) bar graph in figure 3 for the period 1993-1999 shows -3.63 as the lowest point and +26.41 as the highest point. The Decadal Growth Rate (DGR) for the period of 8 years, 1992-1999, is 167 percent.

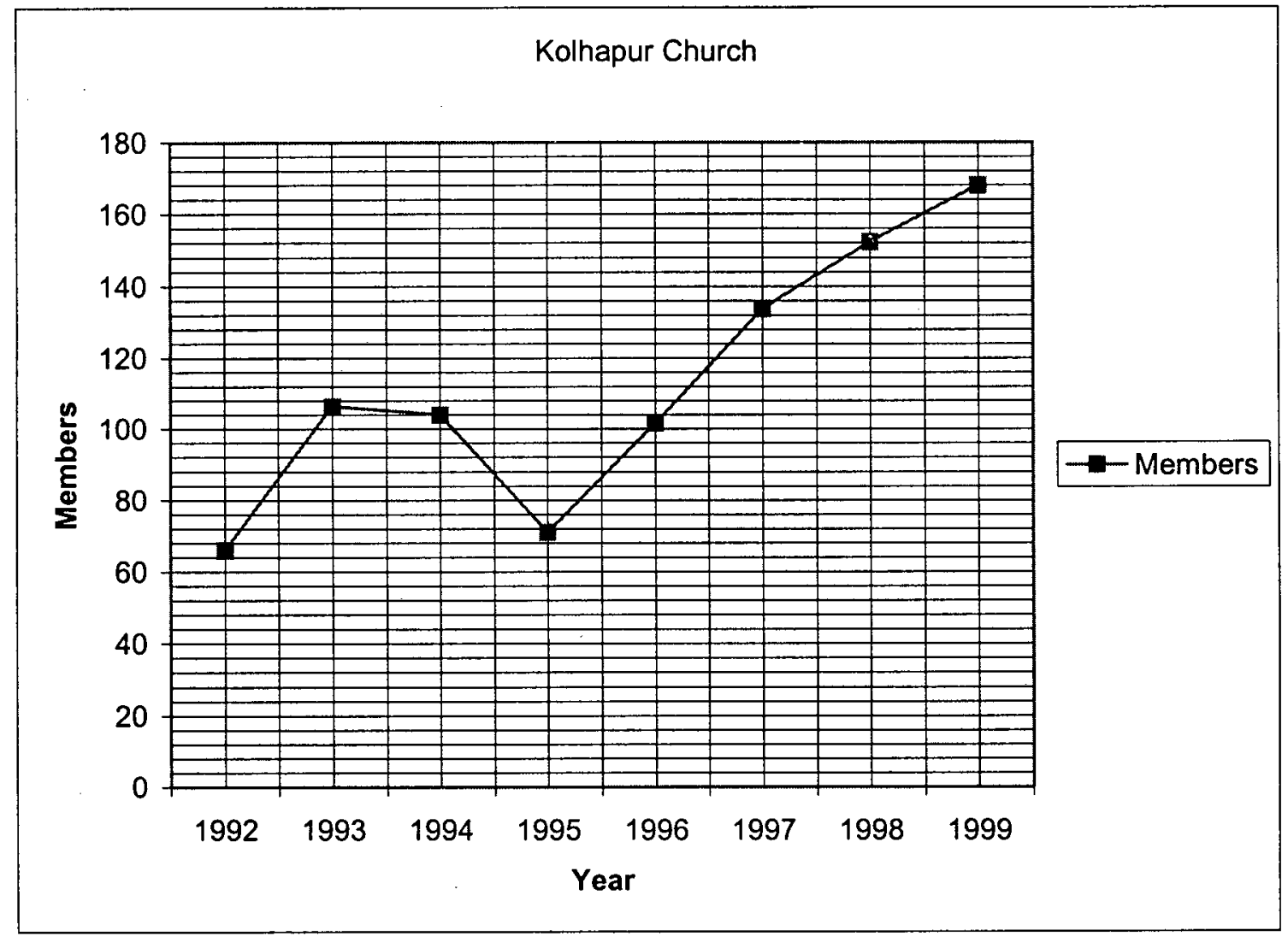

Figure 2. Composite membership of Kolhapur Church. 
The growth patterns in membership of this church over the period of 75 years, 1925 to 1999, are shown in table 16 .

TABLE 16

CHURCH MEMBERSHIP, 1925-1999

\begin{tabular}{lrrrrrrrrrrr}
\hline Year 1925 & 1951 & 1970 & 1985 & 1988 & 1992 & 1996 & 1997 & 1998 & 1999 & \\
Members 47 & 12 & 42 & 125 & 106 & 118 & 159 & 201 & 227 & 258 & \\
\hline
\end{tabular}

\section{Kolhapur Church}

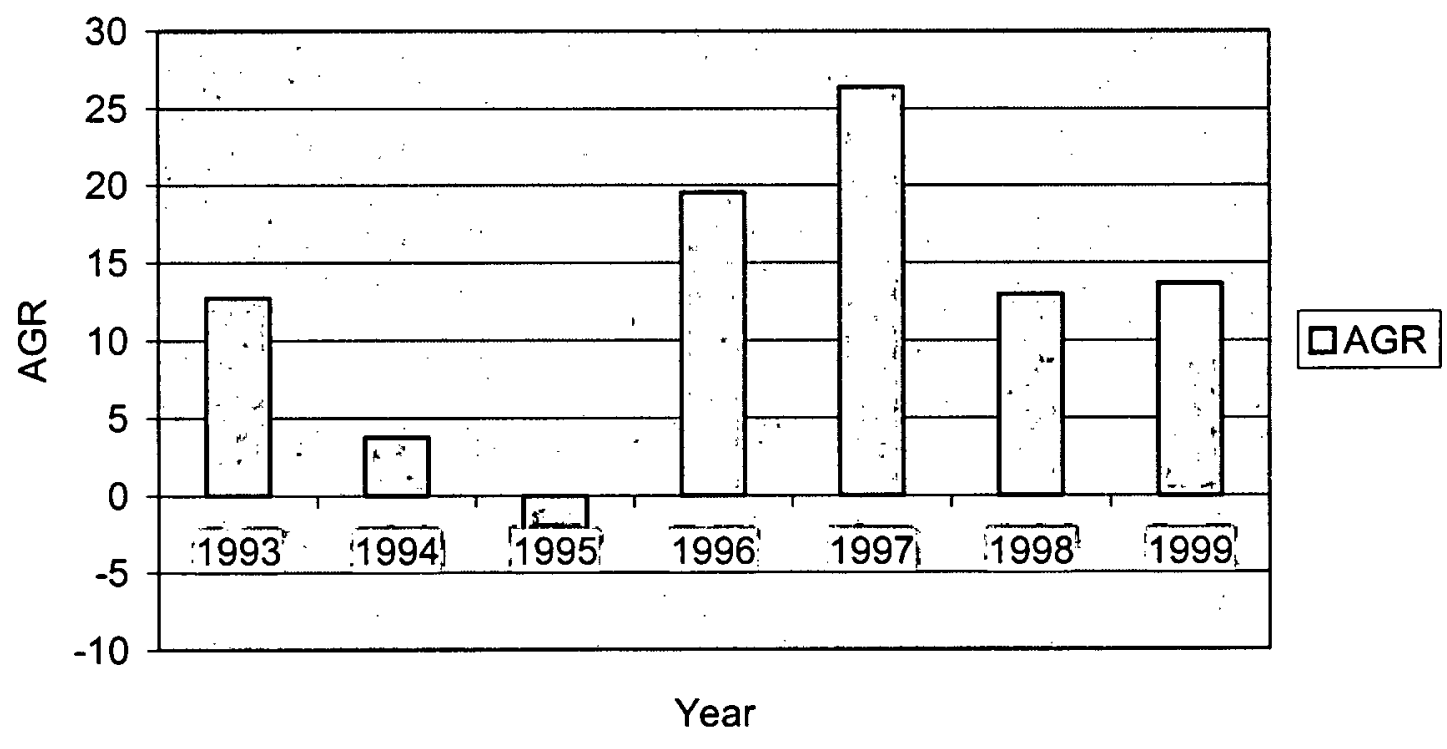

Figure 3. Membership loss and gain, 1992-1999. 
Figure 3 shows the percentage loss and the percentage gain of Kolhapur church for the eight-year period, 19921999. In 1993 the annual growth rate was +12.71 percent; in 1994 it was +3.75 percent; in 1995 it was -3.63 percent and in 1996 it was +19.55 ; in 1997 it was +26.41 percent; in 1998 it was +12.93 percent and in 1999 it was +13.65 percent.

\section{Analysis of Growth Patterns}

The following analysis is based on the information gathered from the interviews and the study of the church records.

Eight pastors have served this church since 1972. Their experience in the growth patterns of this church is described below.

In the 1970s churches were mission oriented, with concern for both spiritual and numerical growth of the church. Large-scale evangelistic programs were conducted on a regular basis. Members were active, loving, and enjoyed great fellowship.

In the 1980 s the major emphasis was on reaching the neighboring villages. Four neighboring villages, 10 to 20 kilometers away, were reached with the message. Several families became Adventists. 
In the early 90s, the trend was to reach various levels of people. Members from unusual cultures and social classes joined the church. Among these were African students, persons from higher classes, as well as teachers, students, young, old, educated, and illiterate. Within 15 to 37 kilometers from Kolhapur, new groups were established between 1992 and 1999. The baptized members at these places number between 17 and 70 , totaling 180 . Three of these places are now under neighboring pastors.

There is no more information available until 1992, when a new pastor arrived. The membership in 1992 was only 118 . The eight-year period, 1992-1999, had a very slow growth in membership. The DGR was 167 percent.

The new pastor began working enthusiastically, visiting people regularly, and holding cottage meetings. By 1993 the membership rose to 133 ; and in 1994 it reached 138 . In 1995 there was a decline to 133 members. When the pastor and the elders of the church were interviewed, two basic reasons for this decline were given. First, there was a Section constituency meeting at the beginning of the year. The pastor, one of the senior and outstanding pastors of the Section, was not promoted. He became discouraged. Second, there was a serious conflict between the church and 
the school authorities over control of the church property and conducting appropriate church programs. It was taken to the Section and Union authorities. Then some young members became involved and the matter even became an issue for police authorities. These situations affected the growth of the church. At the end of the same year, a major evangelistic meeting conducted by R. S. Shinge, former Union president, brought revival to the church. In 1996, the membership rose to 159, and in 1997 to 201. In 1998 the pastor conducted evangelistic meetings and emphasized week of prayer meetings, twice a year in the months of July and November. In 1999, in addition to the week of prayer meetings, N. S. Bhaskar Rao, from the Quiet Hour Ministry, conducted meetings in the church as well as in the churches of other denominations. This helped revive the church, and as a result 14 people were baptized into the church through his ministry.

The AGR bar graph shows many fluctuations in the actual membership and Sabbath School attendance. The average membership of the eight-year period, 1992-99, was 170.87 . But the average church attendance was only 87.17 , only 51 percent of the membership. Sabbath School attendance was 44.55 percent of the membership. On the whole, attendance 
was very low. This was due to irregular visits to the members by church leaders, lack of spiritual liveliness and fellowship, and poor plans and programs in the church. From the statistical data analyzed and the surveys of members and pastors who have served this church, both positive and negative aspects of church growth are observed. The following are the positive factors of church growth.

1. Taking into account the church building, the premises, its long history, and the fame it has due to the noted school attached to it, this church is considered one of the outstanding SDA churches in the Kolhapur district.

2. The major evangelistic thrusts have been in neighboring villages. Mainly by the efforts of the pastor with the help of selected church members, a few village churches and prayer groups have been established. Before 1992 there were four centers. Since 1992 there has been an addition of seven such centers. This is a considerable achievement.

3. There are no social or political barriers to church growth. The people have a strong sense of equality and respect for people of other faiths. Though there is a strong Hindu influence in the city, there is room to reach 
different classes and levels of people.

4. The fast growth in industrialization in this city has both positive and negative effects. Industrialization has kept people busy. There is no time to spend on religious considerations. Yet the tension caused by the busy life and the opportunities for evangelism in newly established areas have opened the way for church planting.

The following are the negative aspects of church growth that caused the church to grow slowly.

1. There are not many celebrations, events, or programs planned in this church. This has kept the laity at a very low spirit.

2. The evangelistic methods followed are very traditional, such as only visiting homes of people and praying, conducting cottage meetings, and following the old Bible study methods. A soul-winning program for this church needs to be developed.

3. The pastor does most of the work of planning the programs, with the laity seldom being involved.

4. There is not much emphasis on training and equipping laity for ministry.

5. The inactive members need more visiting and encouragement from the pastor as well as from the lay 
leaders.

6. More emphasis needs to be placed on the spiritual growth of the laity. The majority of the pastors who served this church in the past stressed maintaining good relations with the members rather than leading members into deeper spirituality and nourishing them on the word of God.

7. Warm fellowship and loving relations need to be developed in the church. There is room for the growth of fellowship, love, and brotherhood; people need to be warmed and encouraged.

8. The prayer life of the church needs to be developed. Praying together in groups needs to be encouraged in the church.

9. Effective and workable programs and plans need to be made in the church in order to keep members active and attract new people. The programs of the church have only nominally influenced the spiritual life of the laity.

10. The two major institutions existing on the same premises, the church and the school, are not always in harmony with each other. At times they cooperate, while at other times they are in conflict over certain issues.

11. More attention from the section administration is needed to meet members' spiritual and personal needs. 
Advising and guiding the pastor is needed. Revival and house churches could be initiated by the encouragement of the section administration. Meeting the needs of the poor and needy should be encouraged. This could be done by emphasizing welfare activities of the church, such as the Dorcas society and raising funds for the poor.

12. The congregation is both English and Marathi speaking. Both well-educated and common people are included in the audience. The church needs two separate worship services appropriate to the needs of the two groups.

13. Separate worship services or prayer groups (house churches) should be organized for the members who live far from the church. Worship times must also be appropriate. Worship should be spirit filled with more prayers and more songs .

The following chapter presents a strategy to revitalize the church. It is based on the above analysis of church growth. In formulating the strategy, consideration was given to making it locally applicable and workable. 
CHAPTER 5

\section{STRATEGIES FOR REVITALIZING \\ THE KOLHAPUR CHURCH}

Revitalizing the churches in Maharashtra, including the Kolhapur Church, is vital. Warren believes that "the key issue for churches in the twenty-first century will be church health, not church growth. . . When congregations are healthy, they grow the way God intends."1 Thus, revitalizing churches is important. To revitalize "means to rediscover and use the resources that will contribute to new life, energy and dynamism of that body."2

On the basis of the analysis of the Kolhapur Church, this chapter presents strategies for revitalizing the church. These are based on the applicable church-growth principles and the lessons drawn from the three model churches presented in chapter 2. The findings and

'Warren, 17.

${ }^{2}$ Simon Cardinal Pimenta, "Revitalization of the Church: Towards the $21^{\text {st }}$ Century," Indian Missiological Review 15 (June 1993): 5 . 
suggestions made by ten active members, ten inactive members, and the pastors who have served this church in the past were also considered. The strategy is divided into two parts: (1) church programs and church celebrations, and (2) discipling through small groups.

Appropriate programs and celebrations in the Kolhapur Church and the initiative of a small-group network with its ministries should revitalize the church to be more active and spiritual. My hope is that in the next five years the church will become a well-known spiritual center in the city, adding 1,000 members. It will also establish several companies in the city and in the surrounding villages.

\section{Programs and Celebrations}

India is a land of many festivals and celebrations. In Maharashtra people take deep interest in various celebrations. Their spirit, unity, and joy are always kept alive.

Until the 70 s the church took interest in conducting programs and celebrations in the church. These helped the members to be more enthusiastic about their faith and the church. Bible study, preaching, singing, and witnessing during different programs and celebrations kept the laity 
spiritually lively. Findings have shown that there are now very few programs and celebrations. So there is need for more programs and celebrations in the Kolhapur Church. Appropriate and effective programs can help revitalize the churches and grow spiritually. Logan states that "programming is simply the means your church employs to bring about its ends to make more and better disciples." ${ }^{1}$ The aim of this strategy is to suggest church programs and celebrations that will help revitalize the church.

\section{Church Programs}

Programs that lead the church to deep spiritual exercise should be planned carefully. Church services are the weekly spiritual events. Revival meetings should be planned at least two times a year and an annual lay mela (lay congress) should lead the church to deep spiritual growth.

\section{Church Services}

One of the basic purposes of the existence of a church is to worship the Lord. Worship is the active response to God, a mind and heart experience with the Creator and with

\footnotetext{
${ }^{1} \operatorname{Logan}$, 173-174 .
} 
fellow believers. ${ }^{1}$ Worship that is properly planned, spirit filled, and dynamic in music, message, and prayer will add much to the spiritual life of the members and will help revitalize the church. The church atmosphere, the preaching, the order of service, and the music all contribute to effective worship.

The following adaptations and strategies should be followed in separately conducted Marathi and English services. One service could be held in the morning and the other in the afternoon, with the exact time to be decided by the members.

Pleasant atmosphere

The church is a place where God's presence is felt; therefore, the atmosphere in the church should be pleasant and favorable to worship. The premises and the church hall should always be clean. The sanctuary should be neatly painted and articles in the church kept neat and in proper order. The verse from Hab 2:20 can be written on the wall behind the stage in an artistic form: "But the Lord is in his holy temple, let all the earth keep silence before him." The grounds around the church should be beautified with

${ }^{1}$ Ibid. 76. 
flowers and potted plants. Sanitary facilities must be kept clean. There should be pure drinking water provided. Deacons, deaconesses, and other helpers should stand at the church entrance before the worship service to greet the members as they arrive.

In Maharashtra a preacher wears a white robe and those who join him on the platform wear white shirts and pants. This is a culturally relevant way of showing reverence. Shoes and chappals (sandals) should be removed before entering the stage, preferably, outside the church.

\section{Preaching}

The preaching should be dynamic, lively, and spirit filled. Revival messages should be selected. The preaching schedule should be arranged well in advance. The preaching should not be traditional, where the preacher alone is delivering the sermon. It should include responses from the audience. Elements of music and songs would be culturally sound and acceptable. The members should respond to the sermon by saying Amen and Prabhula Dhanyawad Aso (Praise the Lord). The preacher should have members respond to certain convicting points by raising their hands or even standing. Bible verses that the preacher is using could be read aloud 
by a lay person from the audience.

Highlighting this kind of preaching, Segler states: "Contemporary preaching, using inductive and narrative approaches, views preaching as a participating event. In this approach the sermon engages the congregation and elicits their participation in the gospel narrative." ${ }^{1}$

Preaching should not be oratorical or use only religious speech, which is like the Western style. In the Eastern style, preaching should be a blending of oral exposition of thoughts and key lessons; then it should be sung, in two to four lines, accompanied by music. A few selected tunes can be used. The statements should be immediately sung, mainly by the preacher or a special group sitting behind the preacher. This style is prevalent in Indian religious expositions and is very appealing to the Indian mind. Christians call this style Kirtan. This style should be used carefully.

Order of worship

The flow of the worship service must be improved. The order of worship should not be too traditional, but in

${ }^{1}$ Franklin M. Segler, Understanding, Preparing For, and Practicing Christian Worship (Nashville, Tennessee:

Broadman and Holman Publishers, 1996), 114. 
consultation with the leaders of the church it should be improved. Major aspects, such as the sermon, prayers, collection of offerings and tithes, and special songs should not be done away with. The time of the worship service should not be strictly and traditionally followed, with Sabbath School beginning at 9:15 and worship at $110^{\prime}$ clock. In consultation with members, the time could be set, suitable to members, but should be during sabbath hours. Church time should not be spent for unholy items such as long announcements or arrangements before entering the stage. Time can be saved by doubling the number of those who collect the offering, by having the special music while the offering is collected, and by avoiding long introductions of the guests and speaker.

Music

The careful selection of music in the church will deepen the effect of the renewal in church life. Music transcends intelligence and reaches directly to the heart. A deeper religious experience can become more meaningful through music and songs. Music uplifts and transforms the worshiper. Maharashtrians are lovers of music; thus there is a major place for music in religious services. 
Music should be of two types: devotional, which is soft and slow, and celebrative, which is spirited and fast. Musical instruments such as the harmonium, tabla (finger drums), guitar, sitar and tal (small bronze cymbals) should be made available by the church or through donations.

All the songs used in the church should be reviewed by a special committee of those who have knowledge of music. Some of the old-time favorites loved by long-time members of the church and which have deep meaning should be selected. The members should be encouraged to write new songs. Songs sung by other Christians could also be adopted. There should be a library of selected religious cassettes and a high-quality sound system.

A church Bhajan Mandal ${ }^{1}$ should be formed in the church. According to Christian tradition in Maharashtra, a prayer meeting arranged by a family is incomplete without inviting a Bhajan Mandal. This group should also read the Bible, present spiritual thoughts, and pray for the families. This will add to the spiritual uplifting of individuals.

\section{Revival Meetings}

${ }^{1}$ Singing group that sings praise songs accompanying a soloist. This is a Maharashtran style which uses local instruments. 
All forms of life pass through a process of health and illness, of growth and decay. This is true with spiritual life also. Shenk feels that "a church can remain vitally alive only as it periodically experiences times of life renewal."1 In order to revitalize the church, revival such as the Pentecost experience is essential. Shenk adds that "God also uses individuals, human experience, sermons, songs, books, sacred places, sacred individuals, human experiences, sacred times and other cultural symbols to move in the lives of people." ${ }^{2}$ Considering this, the following steps should be followed in the Kolhapur Church to bring about revival.

Preparing the atmosphere

Preparing a favorable atmosphere for revival in the church is essential. Autrey states that "preparation is seventy percent of the success of the revival crusade." ${ }^{3}$ The revival period is the harvest time. ${ }^{4}$ Through church sermons, special church meetings, and home visitation, the

${ }^{1}$ Wilbert R. Shenk, Exploring Church Growth (Grand Rapids: Eerdmans, 1983), 157.

${ }^{2}$ Ibid. , 161

${ }^{3}$ Autray, 107.

${ }^{4}$ Ibid. 
pastor and the lay leaders in the church should prepare the minds of the members for revival. Thorough publicity of the revival meetings must begin at least one month before the actual meetings. Attractive and appealing posters and handbills must be printed and distributed. Advertising through local newspaper should be made for ten days before starting the meetings.

Members should sense their need to be filled with the power of the Holy spirit. They should be deeply concerned about the revival of the church. Three areas must be emphasized in the process: (1) the present spiritual condition of the church must be contrasted against the standards required by God; (2) the soon coming of Christ must be emphasized to show that the church has no time to be spiritually weak; (3) the danger of falling behind in fulfilling the great commission of Jesus to preach to all corners of the world must be stressed to help get the world ready for His kingdom.

E. G. White states: "Single persons or a group of individuals, hungry and thirsty after spiritual blessings, who ask in faith will receive accordingly."1 The pastor as the spiritual leader and shepherd of the church should take 'White, Christian Service, 112. 


\section{3}

the lead in the spiritual awakening of the church. He, along with others who feel hungry and thirsty for spirituality, must fast and pray, striving for the power of the Holy Spirit. When this core group is touched and awakened, they must convince other members to have an awakening through revival in the church.

To this core group, made up of the pastor and the spiritually thirsty members, others can be added as they experience a personal revival. Fasting, praying and studying Bible passages on revival should be emphasized. This spirit-filled group should appeal to other church members to seek revival in the church.

\section{The Meetings}

Before the meetings begin, the pastor and the elders should set up committees to prepare and direct the activities of the revival meetings. These should include a steering and program committee, a music committee, and a finance committee. Of special importance are the visitation committee, which should include the pastors and the elders, and the prayer committee, which will organize the church for prayer to intercede for the church, for the sick, and for those who need deliverance. 
The meetings should last for one month, with sessions on Sabbath and three nights each week. The theme will be, "Kolhapur Church: Filled with the Holy Spirit." Mottoes, pledge cards, and pamphlets on revival and the Holy Spirit should be printed.

A speaker who is dedicated, highly spiritual, and who can help revitalize the church will be called. Preference will be given to a speaker who can present the message in the local Marathi language so that translation can be avoided. The speaker will be requested to present deep, spiritual sermons. The preacher should make appeals for confession and re-commitment. Each meeting should be followed by a special prayer session seeking an outpouring of the Holy Spirit and consisting of prayers of rededication, confession, and forgiveness.

Music and singing should be emphasized during the meetings. New songs can be written, printed, and sung. Group songs, bhajans, and special solos can also be arranged.

The visitation and prayer committees should form groups of two or three to visit members and pray with them. Fellowship between two or three families can be arranged, encouraging the families to pray with each other and helping 
them to experience the love and presence of God. The SDA school staff should also be involved in the various groups and activities. Financial assistance should be obtained from the church and school. The preacher, the pastor, and selected lay members should visit those families who are facing troubles such as sickness, discouragement, and harassment from evil spirits.

Follow-up

After the revival meetings are finished, a special church retreat should be arranged. Bible study and prayers should be continued in the church and should also be promoted as a way of life. Revival among the church members must lead to personal spiritual enrichment but must also focus on outreach programs. Small-group ministries (cell groups), such as Bible study groups, prayer groups, fellowship groups, music groups, as well as ministry for the inactive, and Mahila Mandal (women's association), should be started. Revival must lead to renewal at the personal level, in the form of worship in the celebrations of the church, and in the outreach programs of the church.

\section{Lay Mela (Lay Congress)}

One of the major programs that was common twenty years 
ago, that kept people highly spiritual and celebrative, was the Lay Mela (Lay Congress). This is a religious fair in local style. This should be planned by the church board sometime in October or in May when people can be free from their farm work. This type of lay congress gives members opportunity for greeting each other, for more prayer and Bible study, more singing and witnessing. Also, "it gives a person the opportunity to encounter his own 'self', at a depth level which often is not present in the routine of life or in the regular services of the church."1

The following program should be adopted in carrying on the Lay Mela:

1. A special committee should select the place and work out the budget. The financial arrangements should be from donations from members in cash and kind, contributions from the church; funds from the section; and a nominal charge for individuals attending.

2. The meeting should be for three days starting on Thursday afternoon and ending on sabbath evening, with a special Sabbath celebration.

3. The program should include group discussions on

'Findley B. Edge, The Greening of the Church (Waco: Word, 1972), 112, 113 . 
various topics, prayer sessions, group Bible study, Spiritfilled sermons in Marathi, and testimonies. There should be much singing, individually and by groups. Bhajan mandals from various churches should be invited to take part in services and to participate in competitions.

4. There should be time set aside for prayers, meditation on self and God, and pondering and uplifting self to come closer to God. When reflecting on self, four questions should be asked:
a. Who, really, am I?
b. Who is this that I have become?
c. What am I doing with this existence that I

have?

d. Is what I am doing the real meaning of what life is all about?

The second part is to reflect on God's greatness, His love and salvation, His coming, glorious kingdom, and our readiness for that day.

The deep spiritual nature of weekly church services and revival meetings, planned at least two times a year, and the Lay Mela will help to keep the members lively and excited about their religious experience. The quality of the church will be improved. This in turn will help quantitative 
growth of the church, if accompanied with proper training and mobilizing laity for evangelism.

\section{Church Celebrations}

People like to celebrate events, their joys, and religious feelings. The people of Maharashtra, unlike other states in India, are used to many celebrations. These are part of their culture and tradition. The church members also are anxious to celebrate their religious experience. The findings show that two decades ago, the church was involved in many celebrations, but in recent years this aspect has been neglected. More celebrations need to be planned in the Kolhapur Church.

\section{A Church Dedication Day}

A yearly church dedication day should be celebrated to remember the dedication of the church on November 29, 1929. A special thanks and dedication worship and fellowship meal can be arranged in the church. There should be emphasis on prayers, a message on God's house, singing, witnessing, and finally a fellowship meal. Those desiring to give gifts to the church should do so. In celebrating the dedication of the church building, all members should rededicate themselves to God. 


\section{General Christian Festivals}

When Christians have their celebrations, such as Easter and Christmas, special prayer meetings and programs should be arranged in the church. These would not be an imitation of the practices of other Christians, but an opportunity to review the reality of the event and feel its spiritual significance. This will help members to celebrate the spirit of the day. This may help members to stop attending non-SDA churches on these occasions. Encourage them to invite non-SDA friends to the Adventist church.

\section{National Festivals}

On the national festivals, such as Independence Day, on August $15^{\text {th }}$, and on Republic Day, January $26^{\text {th }}$, special prayer meetings can be arranged in the church or in public or government halls. Special prayers should be offered for the nation, its leaders, and the problems facing the nation. The spiritual lessons from the implications of the day could be drawn and renewal and commitment made. For example, on Independence Day, the final deliverance from this sinful world would be remembered. On Republic Day, attention would be focused on the new earth and heaven. 


\section{Discipling through Small Groups}

Discipling must be the highest priority in the Kolhapur Church, for discipling will help members to grow spiritually to the stature of the fullness of Christ (Eph $4: 13$ ). Win Arn and Charles Arn, referring to the Great Commission given by Jesus Christ in Matt 28:19-20, state: "He saw a disciple as one who becomes a follower, who is taught, who is nurtured in the faith, who in turn goes out to make disciples, who are then taught and nurtured in the faith, who then in turn go out." ${ }^{1}$ The process of decision making at the initial stage should lead to a lifelong process of discipleship, ${ }^{2}$ bringing spirituality and maturity, leading to a thorough Christian way of life. ${ }^{3}$ The spiritual growth of the church will help churches grow and multiply.

The discipling of members in the Kolhapur Church can be achieved through small-group ministries. The small-group movement is growing rapidly all over the world. The classic example is that of Paul Cho's Full Gospel Church in Seoul, Korea, with 750,000 members and 50,000 small groups where

'Win Arn and Charles Arn, The Master's Plan for Making Disciples (Pasadena: Church Growth, 1989), 20.

$$
\begin{aligned}
& { }^{2} \text { Elliot, } 47 . \\
& { }^{3} \text { Kraus, } 147 .
\end{aligned}
$$


members are discipled, trained, and equipped for ministry. ${ }^{1}$ "The emphasis upon small-group fellowships as a means of holding people and as a contributing to the maturation process is a decided improvement." ${ }^{2}$ Care and feeding of cell groups and ministry should be the highest priority. ${ }^{3}$ The purpose of small-group ministry is "to study the Bible, . . to give Christians a place where they can grow together, . . to hold each other accountable for life in Christ, to truly care for one-another, and to adequately witness for Christ." ${ }^{4}$ Small groups help "to discover more clearly their identity as persons," they help each other "know that he is accepted and loved as he is." Through a small-group experience "many people have found a new dimension in their Christian life." ${ }^{5}$ Concerning the problem of backsliding in the churches, Warren states: "Small groups are the most effective way of closing the back door of your

${ }^{1}$ Russell Burrill, The Revolutionized Church of the $21^{\text {st }}$ Century (Fallbrook, California: Hart, 1997), v.

${ }^{2}$ Elliot, 48 .

${ }^{3}$ Logan, 8 .

${ }^{4}$ Burrill, 54.

${ }^{5}$ Edge, 115 . 
church."1 The priesthood of all believers is seen in small groups where a pastor enlists the laity, empowers them, and releases them for ministry. The pastor is then free to help small groups grow and multiply, and to do more evangelism. ${ }^{2}$ The New Testament church flourished through small groups. It was a church made up of small groups. According to Acts 2:42-47, their activities consisted of four things: study of the teaching of Jesus, fellowship, breaking bread, and prayer.

The benefits of small groups are seen in service in the church and outside of it, in the multiplication of small groups, and in leadership development. Schwarz states:

Holistic small groups are the natural place for Christians to learn to serve others--both in and outside the group--with their spiritual gifts. The planned multiplication of small groups is made possible through the continual development of leaders as a by-product of the normal group life. The meaning of the term "discipleship", becomes practical in the context of holistic small groups: the transfer of life, not rote learning of abstract concepts. ${ }^{3}$

Small groups built on relations are the greatest need of Christianity. Burrill states: "Small relational groups are the heart of Christianity, and it must be the heart of

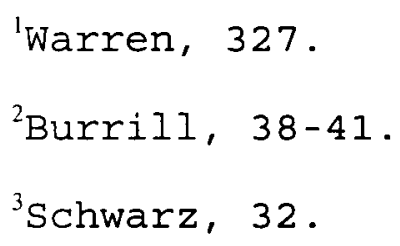


Adventist Church if we are serious about being the church of Jesus for Jesus' church is a relational Church."1

The ministry of small groups for discipleship and outreach is essential. These "small relational groups meeting together for prayer, Bible study, testimonies, mutual encouragement, and then to reach others," should be started in the Kolhapur Church. Ellen G. White foresaw a great revival taking place in God's church in the last days and the church once again assembled in small groups to seek the Lord. ${ }^{2}$

A small-group ministry must be started in the Kolhapur Church. These small groups should be of different types so that people can join the group of their interest, one that appeals to them. This must be because "personalities [and] experiences have been different, and thus needs and interests are different." ${ }^{3}$

The groups should not be isolated from each other but must have mutual dependence and should minister to each other. They can also utilize the resources of other groups

${ }^{1}$ Burrill, 55 .

${ }^{2}$ Ellen G. White, "A Call to All Our People," The Indiana Reporter, February 25, 1903, n.p.

${ }^{3}$ Edge, 115 . 
and refer a person to other groups as need arises. ${ }^{1}$

The small groups to be started in the Kolhapur Church are life-transforming groups, Bible study groups, prayer groups, fellowship groups, singing groups, and good shepherd ministries. Specific information about these different types of groups appears in appendix $\mathrm{C}$.

\section{General Considerations}

While many things could be said about the formation and maintenance of small groups, the following considerations should be taken into account:

1. Each group should have six to ten members.

2. Groups should be formed by geographical areas.

3. Some of these groups could be homogeneous: workers of similar occupations or professions, from similar communities, age, and gender.

4. The group members should be loving, sharing, and caring; they should feel the need of spiritual growth.

5. A group leader should be chosen giving priority to seniority in age, spiritual life, and knowledge of the Bible.

6. The time and place of the meetings should be set by

'Burrill, 84-85. 
the particular group at their convenience.

\section{General Procedures}

At the first meeting members should pledge to:

1. Keep their sharing confidential.

2. Eliminate secular and political discussions, as well as criticism or judgment of any type.

3. Make a priority of sharing each other's burdens, comforting each other, praying for each other and reflecting on Bible passages.

4. They will need to review the ground rules during the first few meetings. The meetings should allow for different activities: fellowship, worship, study, and mission. Each group may choose to emphasize one activity, according to their situation.

\section{Ice Breaking}

Ice breaking, or making persons feel at ease and comfortable, is important to create fellowship. One can ask simple questions relating to life, such as: Where did you live between ages 7-12 and how many brothers and sisters do you have? Who was the person closest to you at that age? When did you first experience God very closely? What is the most significant experience you had last week? Other 
similar questions can be asked, but only one question is asked and answered by all participants in a few minutes.

\section{Praise Time}

Praise songs known to everyone should be sung with proper musical instruments and with full spirit and enthusiasm. All should join in clapping and singing. A song sheet can be printed. It will help the newcomers and those who do not know the words. Two or three persons should be chosen to lead songs with spirit. New songs should be taught.

\section{Reflecting on a Bible Passage}

A Bible passage that speaks of spiritual growth should be read to the group while each one follows it in his or her Bible. Each should find the key words and the meaning of the passage for his or her personal life, then share it with each other.

\section{Prayer Time}

The group prays two by two, or in a circle, or any other way they may choose. Before praying, they should share the goodness of the Lord in the last week and also speak of their personal difficulties and problems. Each other's prayer requests are heard; a word of advice or 
solution is given. Earnest and heartfelt prayers are offered for each other.

\section{Mahila Mandal}

Women in India are a major agent for change, in the church and in society. More women than men attend the Kolhapur Church, as happens in most Indian churches. When a pastor or some of the active members visit homes, men are usually out working. Prayer visits are made to other members of the family, mainly women.

Taking these factors into account, if women in the church are activated for church revitalization, they can influence other family members more deeply and with greater effectiveness than men can.

The following strategy is centered around the Mahila Mandal in the Kolhapur Church.

The pastor and elders of the church should conduct a special meeting with the women in the church. Women can be encouraged in their work and given responsibilities. Hold this type of meeting twice a week for a month in the church or at a convenient place.

Ten to fifteen deeply religious lay women and women staff members from the SDA school, who are enthusiastic about God's work and who are energetic, should be selected 
with careful thought and prayer. Two to three groups, each with four or five ladies, should be formed. They can adopt names for their groups such as, Shomroni Mahila Mandal or Esther Mahila Mandal. Each group would select a mature, religious minded, and possibly educated leader.

Their"major activity will be visiting families and having prayer with the family members present in the homes, usually women. They urge the women in each house to devote time to prayer and Bible study and encourage regular church attendance by the whole family. They can study appropriate Scripture with the women. They should also discuss with the ladies family problems, share their burdens, and suggest proper solutions.

Special weekly prayer meetings for women can be arranged in the church. These should include a major season of prayer, testimonies, and further planning.

Members of the group should help those women who are having family difficulties. They should assist with medical needs, such as medication and hospitalization. Mahila Mandal members should be in close contact with various social and medical welfare agencies, such as free medical health centers, mobile clinics, and family care centers where conflicts between couples and divorce cases are 
handled. They can point the needy women to these services. This way the love of Christ can be shown to family members in a practical way.

\section{House Churches}

Starting house churches in Kolhapur will help the spiritual development of the laity. Many of the members live far from the church and either come very late or not at all. House churches will provide many more opportunities for the members to meet and worship. The attendance will give more room for growth and multiplication. McGavran states: "Each new church gives a number of Christians greater opportunities for leadership, creativity, courageous new actions and innovation of all sorts." ${ }^{1}$

Emphasizing the ministry in the house churches, which was the New Testament model, Burrill states: "Today the church has departed from New Testament norms. Our institutional churches fail to provide community, and we spurn the house church as a relic of days gone by. Yet the modern small group movement may help us to revitalize and establish this forgotten part of the mission of Christ." ${ }^{2}$

${ }^{1}$ Donald McGavran and win Arn, How to Grow a Church (Ventura, CA: Regal, 1985), 127.

${ }^{2}$ Burrill, 64 . 
At locations far from the church, where groups of members live, house churches should be started. Meetings should be on Sabbath and a midweek evening, scheduled when people, especially ladies, are free from their duties. The worship should be informal, with emphasis given to the study of the Word of God, group prayers, singing praises, and witnessing. A local leader should be encouraged and trained. Communion services and other fellowship programs should be planned separately in these house churches.

The programs and celebrations and the small groups suggested to revitalize Kolhapur Church will have an effect on each other. From his experience with small groups, Elliott states: "These smaller units contributed to the dynamic of the corporate worship and the corporate worship in return fed the smaller units."1 As to the effect of revival and small groups, Burrill states that "one of the results of revival is meeting together in small groups to pray and encourage each other." ${ }^{2}$ Members then celebrate their joy of spiritual maturity in large church gatherings such as the Lay Mela.

On the basis of the description and analysis of the

\footnotetext{
${ }^{1}$ Elliot, 48 .

${ }^{2}$ Burrill, 138 .
} 
Kolhapur Church, the above strategies will help revitalize the church through church programs and church celebrations and through discipling by means of small groups. The church programs and celebrations will help the members have a deep spiritual experience and keep them excited and spirited about their faith. The small-group ministry will enhance their spiritual growth through a deeper knowledge of the word of God, recognized by deep and sincere communion with God through prayer, and through sharing and caring for each other's spiritual needs. This spiritual growth will finally lead members to outreach and evangelism. The qualitative and quantitative growth of the church will be achieved.

The plans and strategies proposed for revitalizing Kolhapur Church must be accompanied by the power of the Holy Spirit. The whole church needs to be bathed in prayer for this power and to put its total energy into action. As Warren states, every member should strive to be:

Warmer through fellowship.

Deeper through discipleship.

Stronger through worship

Broader through ministry.

Larger through evangelism. ${ }^{1}$

Thus the Kolhapur Church will grow and multiply both in

'Warren, 49. 
132

quantity and quality, through spiritual and evangelistic dynamics. 
CHAPTER 6

\section{CONCLUSIONS AND RECOMMENDATIONS}

\section{Conclusions}

There is great potential for the growth of the Kolhapur Church. First, however, the church must be fully awakened and revitalized. The church is fully aware of the lively spiritual condition that existed two decades ago and longs to experience it again. The Pentecost experience of the apostles and the tremendous church growth that took place after it should be a clear example for the Kolhapur Church.

From the study, the following conclusions are drawn: There are few programs and celebrations in the church to keep the members celebrative, spirited, and unified. The evangelistic methods are very traditional, such as visiting the homes of the members, conducting cottage meetings, and maintaining nominal relations with the members. Training, equipping, and involving laity in church programs are needed. The inactive need more 
attention and care.

The spiritual growth of the church should be the major concern of the church. The programs and celebrations suggested will help the older members to remember their past and neglected spiritual experience. Thoughtfully and systematically planned church services will strengthen the members' spiritual condition. Revival meetings will uplift and deepen their spirituality, making it celebrative and bringing the members into close spiritual association, uplifting each one closer to God. The growing spirituality will be celebrated by the members in large gatherings such as in the annual Lay Mela.

A powerful small-group ministry will move the Kolhapur Church towards spiritual uplifting, to strengthen the church and do evangelism. Through study, worship, prayer, fellowship, and ministry, each member of the small group will grow spiritually and help others to grow, within the church and outside of it. The Kolhapur Church will then grow both in quality and quantity. It will also be a model church among the SDA churches in Maharashtra. 


\section{Recommendations}

The findings from the church-growth study of the Kolhapur Church suggest the following recommendations for the local church and other church organizations.

\section{For Pastor and Lay Members}

1. The pastor should give highest priority to his own spiritual life and that of his family in order to be the best possible example to the members.

2. The pastor should constantly study the physical and spiritual condition of the church and adopt new methods and plans as needed.

3. The pastor and the lay leaders should never neglect the basic spiritual wants of the members, regularly visiting their homes for prayer and assisting in their temporal and spiritual needs.

4. Lay training and equipping members for church activities and for evangelism should be emphasized in the church.

5. The local church should consider church-growth plans that include modified church services, periodically planned revival meetings, and annual celebrations like the Lay Mela. Prayer ministries such as intercessory 
prayer, prayer for the sick, and power encounters, as well as the ministries of Mahila Mandal and house churches should be emphasized.

For the Section Administration

1. Section leaders should often visit the church to promote programs and plans in which the lay members can be involved. The administrators should check the progress and the results of the programs and plans that they have promoted.

2. The Section administration should support pastoral initiatives to foster church growth, both spiritual and numerical.

3. Section leaders should try to leave pastors and gospel workers in their churches for at least five years so they can complete plans and programs they have begun.

4. Church administration should look favorably on accepting help and guidance from the research-based nonSDA church-growth institutions in India.

\section{For Further Study}

During the course of this research, several topics for further studies have suggested themselves.

1. Adventist church growth in Maharashtra: plans and 
strategies for church multiplication

2. Adventist festivals in Maharashtra in the context of the local culture and biblical truth

3. The history and development of the Adventist work in Maharashtra, methods used, and lessons learned

4. The effects of the Western methods and approaches on the evangelization of India

5. Plans and strategies for church planting, both rural and urban, in India

6. Revival and revitalization of SDA churches in India

7. Cultural issues in Adventism with special reference to the mangalsutra (golden chain used by women as the sacred sign of marriage) and bangles

8. Culturally relevant approaches to worship. 
APPENDIX A

QUESTIONNAIRE FOR MODEL CHURCHES 
QUESTIONNAIRE FOR MODEL CHURCHES

1. Full name of your church

2. How old is your church?

3. For how long have you been in this church? years

4. What is the motto of your church?

5. Kindly tell us about the high events and programs that took place in your church during last five years? (such as evangelistic meetings, celebrations, crusades, spiritual gatherings, etc.)

6. Please state the main publications and written references about the activities of your church?

7. What $\%$ of membership is active in soul winning? Circle: $0 \% \quad 10 \% \quad 20 \% \quad 30 \% \quad 40 \% \quad 50 \% \quad 60 \% \quad 70 \% \quad 80 \% \quad 90 \% \quad 100 \%$

8. Circle the number showing the activeness of the following age group, that contributes to your church growth.

a. 19 years or under

Not Active

What type of activities?

$$
\begin{array}{ccccc}
\text { Active } & & \text { Highly Active } \\
1 & 2 & 3 & 4 & 5
\end{array}
$$

b. 20 to 35 years

1

What type of activities?

c. 36 to 50 years

1

2

3

4

5

What type of activities? 
d. 51 to 65 years

What type of activities?

$\begin{array}{lllll}1 & 2 & 3 & 4 & 5\end{array}$

$\begin{array}{lllll}1 & 2 & 3 & 4 & 5\end{array}$

e. Over 65 years

What type of activities?

f. Men

1

What type of activities?

g. Women

$\begin{array}{lllll}1 & 2 & 3 & 4 & 5\end{array}$

What type of activities?

9. What are the strengths of your church that help it grow?

$\overline{10 . ~ L i s t ~ a n d ~ d e s c r i b e ~ t h e ~ m a i n ~ e v a n g e l i s t i c ~ m e t h o d s ~ y o u ~ u s e . ~}$

11. What are the main principles you follow in the growth of your church?

12. Kindly rate the spiritual condition of your church?

$\begin{array}{lllll}\text { Very } & \text { Low } & & \text { Very High } \\ 1 & 2 & 3 & 4 & 5\end{array}$

What efforts are made to strengthen your church spiritually?

13. What $\%$ of membership is inactive?

What method do you follow to activate them?

14. Kindly state the areas you are improving upon in your church? How? 
15. How often are the pastors changed? What major qualities are expected in your pastors?

16. What has been the contribution to the growth of your church made by the pastor/pastors that have served in the last five years?

17. How does your higher organization contribute to the growth of your church?

18. Please rate the fellowship of your church.

$\begin{array}{lllll}\text { very Cold } & & & \text { Very Warm } \\ 1 & 2 & 3 & 4 & 5\end{array}$

How is warm fellowship grown in your church? Please explain.

19. Circle the number showing type of music in the church 1. Western

2. Eastern

Rate the effect of music in your church

Low High

$\begin{array}{lllll}1 & 2 & 3 & 4 & 5\end{array}$

Describe how music contributes to the growth of your church.

20. How are the newly baptized strengthened and activated?

21. What are your future plans for church growth?

Thank you very much and may God continue to bless you. 
APPENDIX B

SURVEYS ON THE KOLHAPUR CHURCH 


\section{ACTIVE CHURCH MEMBERS' SURVEY}

Kindly respond to all the following questions for your valuable information and suggestions.

1. Circle the number of the age group you are in

1. 19 years or under

2 . 20 to 35 years

3. 36 to 50 years

4. 51 to 65 years

5 . Over 65 years

2. Circle the number showing how long you have been a baptized Adventist member.

1. Less than one year

2. 1 to 5 years

3. 6 to 10 years

4. 11 to 20 years

5 . Over 20 years

3. What responsibility (position) do you hold/have held in the church?

Presently

In the past (show number of years)

4. Circle the $\frac{\circ}{0}$ indicating your relationship with Jesus Christ?

$0 \% \quad 10 \% \quad 20 \% \quad 30 \% \quad 40 \% \quad 50 \% \quad 60 \% \quad 70 \% \quad 80 \% \quad 90 \% \quad 100 \%$

5. Circle the $\frac{\circ}{\circ}$ indicating your assurance of eternal life? $0 \% \quad 10 \% \quad 20 \% \quad 30 \% \quad 40 \% \quad 50 \% \quad 60 \% \quad 70 \% \quad 80 \% \quad 90 \% \quad 100 \%$

6. Circle the $\%$ which shows the extent of your involvement in :

a. Daily personal Bible study.

$0 \% \quad 10 \% \quad 20 \% \quad 30 \% \quad 40 \% \quad 50 \% \quad 60 \% \quad 70 \% \quad 80 \% \quad 90 \% \quad 100 \%$

b. Daily personal prayer.

$0 \% \quad 10 \% \quad 20 \% \quad 30 \% \quad 40 \% \quad 50 \% \quad 60 \% \quad 70 \% \quad 80 \% \quad 90 \% \quad 100 \%$

C. Daily family worship.

$0 \% \quad 10 \% \quad 20 \% \quad 30 \% \quad 40 \% \quad 50 \% \quad 60 \% \quad 70 \% \quad 80 \% \quad 90 \% \quad 100 \%$

d. Witnessing in every day activities.

$0 \% \quad 10 \% \quad 20 \% \quad 30 \% \quad 40 \% \quad 50 \% \quad 60 \% \quad 70 \% \quad 80 \% \quad 90 \% \quad 100 \%$ 
e. Attending Sabbath school regularly and on time $0 \% \quad 10 \% \quad 0 \% \quad 30 \% \quad 40 \% \quad 50 \% \quad 60 \% \quad 70 \% \quad 80 \% \quad 90 \% \quad 100 \%$

f. Tithing regularly and faithfully.

$0 \% \quad 10 \% \quad 20 \% \quad 30 \% \quad 40 \% \quad 50 \% \quad 60 \% \quad 70 \% \quad 80 \% \quad 90 \% \quad 100 \%$

g. Working to win non-Adventist relatives and friends. $0 \% \quad 10 \% \quad 20 \% \quad 30 \% \quad 40 \% \quad 50 \% \quad 60 \% \quad 70 \% \quad 80 \% \quad 90 \% \quad 100 \%$

h. Helping neighbors in their personal problems. $0 \% \quad 10 \% \quad 20 \% \quad 30 \% \quad 40 \% \quad 50 \% \quad 60 \% \quad 70 \% \quad 80 \% \quad 90 \% \quad 100 \%$

7. Have you been engaged in some type of soul winning activities? 1. Yes. 2.No. Please specify the type of activities

8. Did you set a personal soul winning goal this year? 1. Yes 2. No By what method?

9. How well prepared are you for the work of soul winning? Circle the $\%$. $0 \% \quad 10 \% \quad 20 \% \quad 30 \% \quad 40 \% \quad 50 \% \quad 60 \% \quad 70 \% \quad 80 \% \quad 90 \% \quad 100 \%$

What type of training or programs you need to be will equipped for soul winning? Please state

10. How helpful do you find the following resources in strengthening you spiritual life and Christian experience?

a. Sabbath School Programs

$0 \% \quad 10 \% \quad 20 \% \quad 30 \% \quad 40 \% \quad 50 \% \quad 60 \% \quad 70 \% \quad 80 \% \quad 90 \% \quad 100 \%$

b. Sabbath School Lesson Study

$0 \% \quad 10 \% \quad 20 \% \quad 30 \% \quad 40 \% \quad 50 \% \quad 60 \% \quad 70 \% \quad 80 \% \quad 90 \% \quad 100 \%$

c. Church Services

$0 \% \quad 10 \% \quad 20 \% \quad 30 \% \quad 40 \% \quad 50 \% \quad 60 \% \quad 70 \% \quad 80 \% \quad 90 \% \quad 100 \%$

d. Sermon in church sevices

$0 \% \quad 10 \% \quad 20 \% \quad 30 \% \quad 40 \% \quad 50 \% \quad 60 \% \quad 70 \% \quad 80 \% \quad 90 \% \quad 100 \%$ 
e. Prayer life of the church

$0 \% \quad 10 \% \quad 20 \% \quad 30 \% \quad 40 \% \quad 50 \% \quad 60 \% \quad 70 \% \quad 80 \% \quad 90 \% \quad 100 \%$

f. Personal Bible Study

$0 \% \quad 10 \% \quad 20 \% \quad 30 \% \quad 40 \% \quad 50 \% \quad 60 \% \quad 70 \% \quad 80 \% \quad 90 \% \quad 100 \%$

9. Use of music in the church

$0 \% \quad 10 \% \quad 20 \% \quad 30 \% \quad 40 \% \quad 50 \% \quad 60 \% \quad 70 \% \quad 80 \% \quad 90 \% \quad 100 \%$

h. Adventist literature

$0 \% \quad 10 \% \quad 20 \% \quad 30 \% \quad 40 \% \quad 50 \% \quad 60 \% \quad 70 \% \quad 80 \% \quad 90 \% \quad 100 \%$

i. Pastoral care

$0 \% \quad 10 \% \quad 20 \% \quad 30 \% \quad 40 \% \quad 50 \% \quad 60 \% \quad 70 \% \quad 80 \% \quad 90 \% \quad 100 \%$

j. Plans and programs promoted by section administration

$0 \% \quad 10 \% \quad 20 \% \quad 30 \% \quad 40 \% \quad 50 \% \quad 60 \% \quad 70 \% \quad 80 \% \quad 90 \% \quad 100 \%$

11. What type of fellowship you have in the church? Circle a letter.

a. Cold and exclusive - I don't feel at home

b. People are friendly but I cannot develop friendly relations

c. A friendly atmosphere; I have made some friends.

d. Very warm and loving, like a family.

12. Circle the percentage which best indicates the emphasis your church places upon:

a. Soul winning

$0 \% \quad 10 \% \quad 20 \% \quad 30 \% \quad 40 \% \quad 50 \% \quad 60 \% \quad 70 \% \quad 80 \% \quad 90 \% \quad 100 \%$

b. Level of Adventist standards

$0 \% \quad 10 \% \quad 20 \% \quad 30 \% \quad 40 \% \quad 50 \% \quad 60 \% \quad 70 \% \quad 80 \% \quad 90 \% \quad 100 \%$

c. Care and involvement of new members in church activities

$0 \% \quad 0 \% \quad 20 \% \quad 30 \% \quad 40 \% \quad 50 \% \quad 60 \% \quad 70 \% \quad 80 \% \quad 90 \% \quad 100 \%$

d. Making members active in church

$0 \% \quad 10 \% \quad 20 \% \quad 30 \% \quad 40 \% \quad 50 \% \quad 60 \% \quad 70 \% \quad 80 \% \quad 90 \% \quad 100 \%$

e. Spiritual liveliness of the church

$0 \% \quad 10 \% \quad 20 \% \quad 30 \% \quad 40 \% \quad 50 \% \quad 60 \% \quad 70 \% \quad 80 \% \quad 90 \% \quad 100 \%$ 
f. Following church manual carefully

$0 \% \quad 10 \% \quad 20 \% \quad 30 \% \quad 40 \% \quad 50 \% \quad 60 \% \quad 70 \% \quad 80 \% \quad 90 \% \quad 100 \%$

9. Effective music

$0 \% \quad 10 \% \quad 20 \% \quad 30 \% \quad 40 \% \quad 50 \% \quad 60 \% \quad 70 \% \quad 80 \% \quad 90 \% \quad 100 \%$

In what areas is the church growing? Please write in few Iines:

In what areas is the church not growing? Please write in few Iines.

Why?

Your suggestions to make changes

13. Circle the \% which shows the emphasis your pastor places upon:

a. Soul winning

$0 \% \quad 10 \% \quad 20 \% \quad 30 \% \quad 40 \% \quad 50 \% \quad 60 \% \quad 70 \% \quad 80 \% \quad 90 \% \quad 100 \%$

b. Spiritual life of the church

$0 \% \quad 10 \% \quad 20 \% \quad 30 \% \quad 40 \% \quad 50 \% \quad 60 \% \quad 70 \% \quad 80 \% \quad 90 \% \quad 100 \%$

C. Keeping members very active

$0 \% \quad 10 \% \quad 20 \% \quad 30 \% \quad 40 \% \quad 50 \% \quad 60 \% \quad 70 \% \quad 80 \% \quad 90 \% \quad 100 \%$

d. Making plans and programs for church growth

$0 \% \quad 10 \% \quad 20 \% \quad 30 \% \quad 40 \% \quad 50 \% \quad 60 \% \quad 70 \% \quad 80 \% \quad 90 \% \quad 100 \%$

14. Concern of the Section Administration towards your church.

$0 \% \quad 10 \% \quad 20 \% \quad 30 \% \quad 40 \% \quad 50 \% \quad 60 \% \quad 70 \% \quad 80 \% \quad 90 \% \quad 100 \%$ 
Your comments and expectations.

Thank you very much! 


\section{INACTIVE MEMBERS' SURVEY}

1. Circle the number of the age group you are in:
a. 19 years and under
b. 20-35 years
c. 36-50 years
d. 51-65 years
f. over 65 years

2. Circle the $\frac{\circ}{6}$ indicating your relationship that you have with Jesus Christ?

$0 \% \quad 10 \% \quad 20 \% \quad 30 \% \quad 40 \% \quad 50 \% \quad 60 \% \quad 70 \% \quad 80 \% \quad 90 \% \quad 100 \%$

3. When did you become Adventist Member? Year

4. What attracted you most to become a church member?

Circle the letter:
a. I was raised as an Adventist
b. The church beliefs appealed to me
c. The warm fellowship of the believers
d. I was convinced by church pastor
e. Friends/relatives led me to church
f. Any other

5. How long were you active in church after your baptism?

6. How helpful did you find the following resources in strengthening your spiritual life and Christian experience? Circle the \%

a. Sabbath School Program

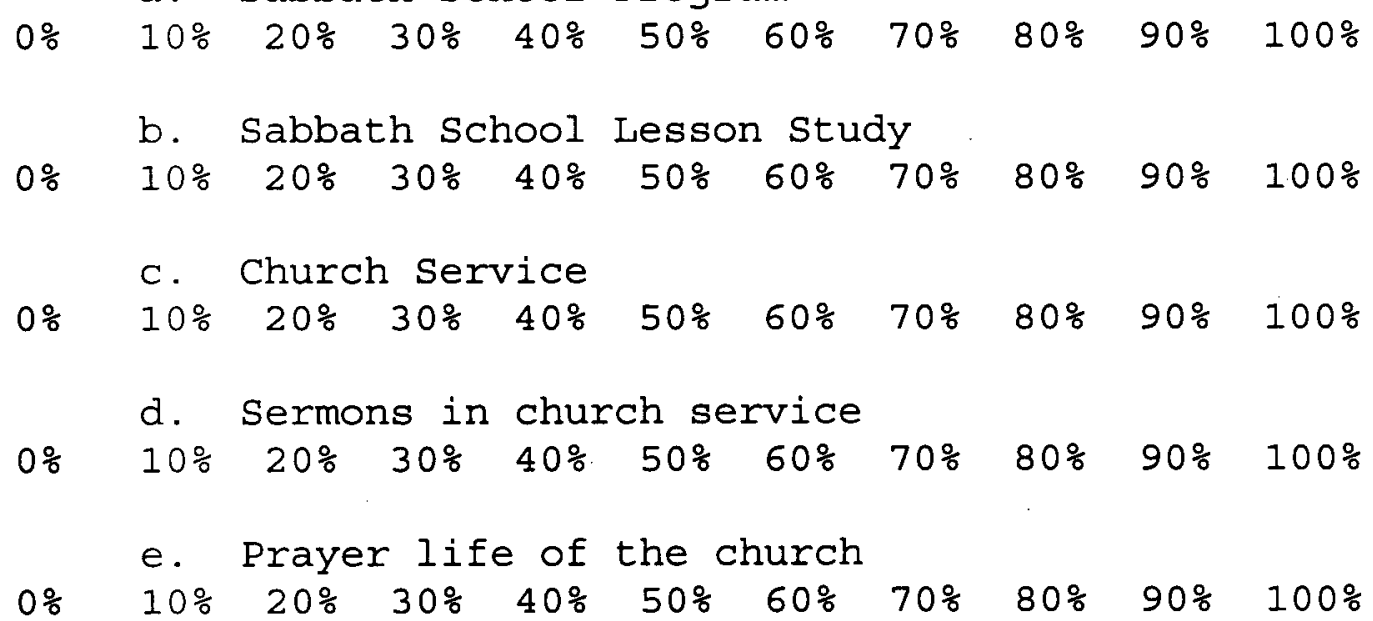


f. Personal Bible study

$0 \% \quad 10 \% \quad 20 \% \quad 30 \% \quad 40 \% \quad 50 \% \quad 60 \% \quad 70 \% \quad 80 \% \quad 90 \% \quad 100 \%$

9. Use of music in the church

$0 \% \quad 10 \% \quad 20 \% \quad 30 \% \quad 405 \quad 50 \% \quad 60 \% \quad 70 \% \quad 80 \% \quad 90 \% \quad 100 \%$

h. Adventist literature

$0 \% \quad 10 \% \quad 20 \% \quad 30 \% \quad 40 \% \quad 50 \% \quad 60 \% \quad 70 \% \quad 80 \% \quad 90 \% \quad 100 \%$

i. Pastoral care

$0 \% \quad 10 \% \quad 20 \% \quad 30 \% \quad 40 \% \quad 50 \% \quad 60 \% \quad 70 \% \quad 80 \% \quad 90 \% \quad 100 \%$

j. Plans and programs promoted by section

Administration.

$0 \% \quad 10 \% \quad 20 \% \quad 30 \% \quad 40 \% \quad 50 \% \quad 60 \% \quad 70 \% \quad 80 \% \quad 90 \% \quad 100 \%$

7. Circle the $\%$ which best indicates the emphasis the church used to place upon.

\section{a. Soul winning}

$0 \% \quad 10 \% \quad 20 \% \quad 30 \% \quad 40 \% \quad 50 \% \quad 60 \% \quad 70 \% \quad 80 \% \quad 90 \% \quad 100 \%$

b. Level of the Adventist standards

$0 \% \quad 10 \% \quad 20 \% \quad 30 \% \quad 405 \quad 50 \% \quad 60 \% \quad 70 \% \quad 80 \% \quad 90 \% \quad 100 \%$

c. Care and involvement of new members in church activities

$0 \% \quad 10 \% \quad 20 \% \quad 30 \% \quad 40 \% \quad 50 \% \quad 60 \% \quad 70 \% \quad 80 \% \quad 90 \% \quad 100 \%$

d. Making members active in church

$0 \% \quad 10 \% \quad 20 \% \quad 30 \% \quad 40 \% \quad 50 \% \quad 60 \% \quad 70 \% \quad 80 \% \quad 90 \% \quad 100 \%$

e. Spiritual liveliness of the church

$0 \% \quad 10 \% \quad 20 \% \quad 30 \% \quad 40 \% \quad 50 \% \quad 60 \% \quad 70 \% \quad 80 \% \quad 90 \% \quad 100 \%$

f. Following church manual carefully

$0 \% \quad 10 \% \quad 20 \% \quad 30 \% \quad 40 \% \quad 50 \% \quad 60 \% \quad 70 \% \quad 80 \% \quad 90 \% \quad 100 \%$

g. Effective music

$0 \% \quad 10 \% \quad 20 \% \quad 30 \% \quad 40 \% \quad 50 \% \quad 60 \% \quad 70 \% \quad 80 \% \quad 90 \% \quad 100 \%$

h. Warm fellowship of laity

$0 \% \quad 10 \% \quad 20 \% \quad 30 \% \quad 40 \% \quad 50 \% \quad 60 \% \quad 70 \% \quad 80 \% \quad 90 \% \quad 100 \%$

8. Mark the $\%$ to show the importance of each of the following factors in your decision to stop attending the church: 
a. Mistreated by members

$0 \% \quad 10 \% \quad 20 \% \quad 30 \% \quad 40 \% \quad 50 \% \quad 60 \% \quad 70 \% \quad 80 \% \quad 90 \% \quad 100 \%$

b. Social pressure from non-Adventist friends

$0 \% \quad 10 \% \quad 20 \% \quad 30 \% \quad 40 \% \quad 50 \% \quad 60 \% \quad 70 \% \quad 80 \% \quad 90 \% \quad 100 \%$

c. Lack of fellowship

$0 \% \quad 10 \% \quad 20 \% \quad 30 \% \quad 40 \% \quad 50 \% \quad 60 \% \quad 70 \% \quad 80 \% \quad 90 \% \quad 100 \%$

d. Don't believe some of the church teachings

$0 \% \quad 10 \% \quad 20 \% \quad 30 \% \quad 40 \% \quad 50 \% \quad 60 \% \quad 70 \% \quad 80 \% \quad 90 \% \quad 100 \%$

e. Standards too strict

$0 \% \quad 10 \% \quad 20 \% \quad 30 \% \quad 40 \% \quad 50 \% \quad 60 \% \quad 70 \% \quad 80 \% \quad 90 \% \quad 100 \%$

f. Church teachings and practices do not match

$0 \% \quad 10 \% \quad 20 \% \quad 30 \% \quad 40 \% \quad 50 \% \quad 60 \% \quad 70 \% \quad 80 \% \quad 90 \% \quad 100 \%$ needs

g. Worship and other programs do not meet my spiritual $0 \% \quad 10 \% \quad 20 \% \quad 30 \% \quad 40 \% \quad 50 \% \quad 60 \% \quad 70 \% \quad 80 \% \quad 90 \% \quad 100 \%$

h. Any other factors? Please specify

9. What was the immediate reason to stop coming to church?

10. What efforts have the pastor or members made to bring you back into full fellowship?

11. What change do you want to see in the church before you again become a church member? specify.

The change you expect from the pastor: Specify 
The change you expect from the church members. Specify

The change you expect from the Section Administration. Specify

12. What suggestions would you make for the church to grow spiritually and in number?

Thank you very much! 
SURVEY OF PASTORS WHO HAVE SERVED THE KOLHAPUR CHURCH

1. How long did you pastor this church? years. 19 to 19

2. When you were pastor what was your experience?

3. Please state in which areas the church was growing? (membership, spiritually, evangelism, fellowship, etc.)

4. If you would become pastor again, what would you do for the growth of the church in both number and in spiritually?

5. How would you rate the following? Circle the appropriate number:

$\begin{array}{llllll}\text { a. Present church evangelism } & 1 & 2 & 3 & 4 & 5 \\ \text { b. Concern for the new members } & 1 & 2 & 3 & 4 & 5 \\ \text { c. Concern for old members } & 1 & 2 & 3 & 4 & 5 \\ \text { d. Pastoral care } & 1 & 2 & 3 & 4 & 5 \\ \text { e. Spiritual life of the church } & 1 & 2 & 3 & 4 & 5 \\ \text { f. Keeping the members active } & 1 & 2 & 3 & 4 & 5 \\ \text { g. Use of music } & 1 & 2 & 3 & 4 & 5 \\ \text { h. Sermons } & 1 & 2 & 3 & 4 & 5 \\ \text { i. Sabbath school program } & 1 & 2 & -3 & 4 & 5\end{array}$

6. What would you suggest for present effective pastorship? 
7. What do you suggest that the Section Administration do to help the church grow?

8. Describe te most effective programs and plans which you followed during your tenure.

9. Which of these should be still carried on for the church to grow?

10. To the changing time and situation, what new plans do you suggest for the church to grow?

11. Please state the areas where church should improve upon.

How should this take place?

Thank you very much and may God continue to bless you. 
APPENDIX C

VARIOUS TYPES OF SMALL GROUPS 
Life Transformation Groups

The guidelines for life transformation groups mentioned below have been adopted from the class, MSSN 735, Strategies for Church Growth. ${ }^{1}$

Groups of two to three should be formed, involving all the faithful members of the church. This should be a voluntary activity, not forced. The group meets once a week, for approximately one hour. If a fourth person is added to the group, the group must divide. The groups should not be joined to each other in order to keep the confidentiality and honesty of the group. There is no particular leader and curriculum other than the Holy Spirit to guide. The word of God and open expressions are the curriculum.

In the informal meeting the following activities take place: (1) sincere, heart felt prayers by each member for the forgiveness of sin, for the cleansing of the hearts, for the outpouring of the Holy spirit, and for each other; (2) reading and reflecting on a selected passage of the Bible, in search of spiritual values for life; (3) the expression of individual burdens, spiritual needs, confession of sins and wrong acts, and the search for spiritual advice from others. In an atmosphere of confidentiality, honesty, and accountability ten questions should be asked of each other. These are the questions about sin committed in the past week; about spiritual condition and progress, and about involvement in evangelism. Finally they pray for the spiritual growth and for the needs of each other. The time and place for a next meeting is set.

Besides praise songs, Bible study, witnessing, and prayer, the major emphasis in life transformation groups is on the inner search of the heart, on opening up to others and to God and seeking His help for strength. Through Bible study and prayer the emptiness of the heart is filled with the power of the Holy spirit.

Edge describes life transformation groups as "searching" groups. They "help people 'come alive' in their personal encounter with self and with God." " "A searching

${ }^{1}$ Erich W. Baumgartner, Class Outline for MSSN 735, Strategies for Church Growth, Andrews University, Spicer Memorial College Extension, Pune, 1997.

${ }^{2}$ Edge, 114 . 
group is composed of people who, at a significant level in their lives, are searching for a deeper reality of God." According to Edge this group has "either a deep sense of disillusionment about the church or a significant feelings of personal emptiness in their spiritual lives or both." $\mathrm{He}$ also notes that "they also have a deep desire to discover that reality which does give meaning." ${ }^{1}$ These are usually leaders of an institutional church who have a feeling of emptiness or meaninglessness. ${ }^{2}$

The batsic purpose of the search groups "is to probe for a deeper meaning in religion and life which one has not yet discovered. It is a search to discover a deeper reality of God in life. This is a group in which one shares his frustrations, questions, and doubts." Becoming God's person is the deep desire of their life and the Holy spirit helps them to be transformed. ${ }^{3}$

Search groups should be relatively smaller than Bible study or prayer groups. They should have between six and ten persons, so that all will open their life to others, and to receive the ministry of others.

The disciplines followed are: (1) attending regularly, (2) daily praying for each other, (3) studying the Word of God, (4) keeping total confidentiality; and (5) sharing with each other. ${ }^{4}$

Through life transformation groups a person finds new life and goes out to serve.
I'Ibid., 118
${ }^{2}$ Ibid.
${ }^{3}$ Ibid. , 119.
${ }^{4}$ Ibid, $122-128$. 


\section{Bible Study Groups}

Those interested in Bible study should join these groups. "These are usually made up of people who have not found the Bible study in their particular church to be satisfying." I Five to twelve members should meet informally in a place and time convenient to the group. At the meetings the groups may decide on different types of study.

The Bible study groups should apply the lessons to their personal lives. After study and discussion, they should have time for prayer. They should also plan for fellowship activities.

\section{Voice of Prophecy Lessons}

A group may choose to study the Bible using the Voice of Prophecy lessons. Questions at the end can be filled in before coming to the meeting. During the group meeting the members discuss the points studied. A question-and-answer session will open opportunities for members to dialoging with each other. It is acceptable to include in this group people who have not become baptized members of the church yet.

\section{Other Bible Study Lessons}

The Bible Easy Lessons could also be used in

translation, following the same procedure. H.M.S Richard's or Mark Finley's Bible studies could be translated and printed in Marathi. There should be open discussion and a time for questions and answers.

Following are topics on which lessons could be prepared:

1. Life and teachings of Jesus.

2. The Acts of the Apostles.

3. The epistles in the New Testament.

4. Stories from the old Testament.

5. Tapes of major passages of the Bible available for the illiterate, blind, and aged.

\section{Apocalyptic Writings}

Some groups could study apocalyptic writings, writings on the end of time, and the second coming. Books on Daniel

\footnotetext{
Ibid, 116
} 
and Revelation, as well as the writings of Ellen White, could be studied. Members would be free to decide what aspect of the end time and the second coming they would like to study.

\section{Prayer Groups}

According to E. G. White, prayer is "the opening of the heart to God as a friend." It is also "the key in the hands of faith to unlock heavens storehouse, where are treasured the boundless resources of omnipotence." ${ }^{1}$

Those who feel a deep need of prayer should join these informal groups at an agreed upon time and place. Usually these are people 'who have a deep belief in and commitment to intercessory prayer," share their common concern and spend more time in prayer." Burrill states: "The power of prayer in the small groups cannot be underestimated. It is really the life of the small groups". ${ }^{3}$

These prayer groups could choose a name like "David's prayer band" or "Daniel's prayer band". They should have group prayer followed by praise songs, short witnessing and a short Bible study. After asking for prayer requests and needs, there should be a time of prayer using different methods.

The type of prayers emphasized in these groups are: intercessory prayer, prayer for the sick, and prayer for deliverance.

Intercessory Prayer

Intercessory prayer is pleading to the Lord on behalf of a person or group. Such a prayer is offered to meet spiritual and temporal needs: health, deliverance from evil spirits, outpouring of the Holy spirit, and spiritual growth. Requests are also made to meet physical, social, and emotional needs. Allen sates, "Intercessory prayer-prayer for the sick among us, for unconverted relatives and

${ }^{1}$ Ellen. G. White. Steps to Christ (Washington D.C.: Review and Herald, 1981), 97-99.

${ }^{2}$ Edge, 116, 117

${ }^{3}$ Burrill, 136. 
friends and for those who cannot pray for themselves, should grow as vital ministry among God's people."

Some classic examples of intercessory prayers are the ones Moses offered for Israel at Mount Sinai (Exod 32:32) and when Israel was fighting against Amalek (Exo 17:11). Samuel interceded for Israel at Mizpah (1 Sam 7:5) and Daniel prayed for the deliverance of Israel from Babylonian bondage (Dan 9:3-20). In John 17, Jesus interceded for himself (vss 1-5), for his disciples (vss 6-19), and for all the believers (vss 20-26).

Small groups interested in intercessory prayers must first prepare themselves in intensive prayer, heart searching, and being right with fellow beings and with God. After praise songs, testimonies, and reflective Bible study, the group should begin the prayer session. The person for whom prayers are offered should tell the group leader his or her specific needs and problems. The person should be comforted by the assurance of the power of God and of the working of the Holy Spirit. All should kneel and place their hands on the head of the one being bathed in prayer. All the members can pray at one time or in turn; they can also praise the Lord by singing praise songs. After prayer, words of comfort and assurance should be spoken to the person.

\section{Prayer for Healing}

The ministry of Jesus was threefold: preaching, teaching, and healing. He emphasized healing the sick, delivering people from their pain. This led to spiritual healing and to salvation. Christ gave his disciples the power "to heal all manner of sickness and all manner of diseases" (Matt 10:1).

Today many Christians need physical and spiritual healing. MacNutt states that "too many Christians are broken in a destructive way--so badly broken that they cannot carry out the great commandment of loving God and neighbor. Their turmoil prevents them from carrying out God's will."2 Experiences of many pastors have shown that many non-Christians flock to prayer meetings where a healing

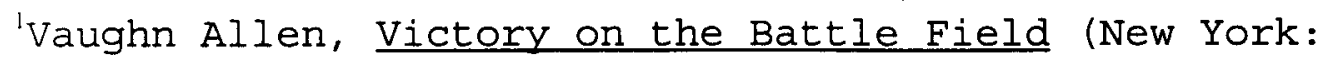
Teach Services, Brushton, 1988), 91.

${ }^{2}$ Allen, 75 .
} 
ministry is carried on. People come with their little knowledge of Jesus Christ with simple and deep faith. When they are prayed for and relieved, they join the church and also invite their friends and relatives.

Francis McNutt categorizes four kinds of sicknesses and four kinds of healing for which prayers should be offered. Sickness of the spirit caused by personal sin needs prayer for repentance.

1. Emotional sickness and problems caused by past hurts need prayer for inner healing.

2. Physical sickness needs prayer for physical healing.

3. Sickness caused by demonic oppression needs prayer for deliverance. ${ }^{1}$

The procedure in a prayer session for healing ministry should be the same as that of intercessory prayer. Specific prayer for specific sickness should be offered in simple faith and trust.

The group also should plan fellowship activities. These groups should visit people's homes and pray with them. Also, these prayer groups, in consultation with each other should arrange a prayer chain in the church with at least one member or family praying one after another for an hour or two. The chain can then be extended to cover day and night.

\section{Power Encounter Groups}

In India many people are troubled by evil spirits. These evil powers cause troubles, problems, and sicknesses. Deliverance through a power encounter is needed to liberate these people. Through such encounters a person possessed or tormented by evil spirits can be delivered. ${ }^{2}$ These victories over evil have helped church growth in a mighty way ${ }^{3}$

These groups are different from regular prayer groups in the church in that they are smaller (only four or five persons) and are made up of highly spiritual prayer warriors, living in touch with the power of the Holy spirit.

'Francis MacNutt, Healing, (Notre Dame, Indiana: Ave Maria, 1974). 162, 163.

${ }^{2}$ Ibid., 208 .

${ }^{3}$ Hedlund, 182 . 
Their activities result in rescuing demon-troubled individuals and families.

For a month or two they should pray for the power of the Holy spirit. They should also study various resources, including Ellen White's books and be acquainted with various aspects of the devil's working. Before going out, all the members should confess all sins, affirm their faith, and sense the power of the Holy spirit.

When they reach the house of the demon-troubled person, they should take authority over the time, place, and persons in the family. They should encourage the person to sit before them and have a season of prayer. By the power of the Holy spirit and in the name of Jesus the devil must be challenged and rebuked to leave the person. There should be more prayers by the group one at a time or all together, praying individually but aloud. The family members also should join in praying. The group members should pronounce praise words and sing praise songs when the leader is praying. Care should be taken to see that the devil has completely left. The whole family must be advised to live a holy life, study the Word of God, and continue in prayer.

The weapons of power encounter warfare are "Bible study, prayer and faith in the saving power of Christ."1 Other spiritual weapons mentioned by Allen are praising the Lord, singing glory to God, giving testimonies, and witnessing. ${ }^{2}$

Testimonies of miracles that took place during power encounters should be given in the small groups and in church. Families can be encouraged to contact these groups for deliverance from various kinds of devil torment. On Sabbath afternoons and on Wednesday of every week this ministry should be conducted in the church at a set time. Non-Christians can also be encouraged to get help through this ministry.

As the individuals and families feel delivered from evil, they will come closer to God and their spiritual lives will be uplifted. This ministry will be a powerful instrument of church revitalization and evangelism.

$$
\begin{aligned}
& \text { 'Allen, } 113 . \\
& \text { 'Ibid, } 160 .
\end{aligned}
$$




\section{Fellowship Groups}

Those interested in close fellowships should join these informal groups that meet at a specific place and time. At the gathering, they should pray, study the word of God and enter into the planned fellowship program. This time can provide an opportunity to empty their hearts to each other, expressing their spiritual needs, and having prayers. A fellowship meal or refreshment may be arranged. Plans should be made to help specific needs such as visiting homes or hospitals, attending to legal matters, or any other needs of the individuals. There should be a prayer session. The fellowship of the small groups can also be extended to all the church members in the same manner as exercised in the group.

\section{Singing Groups}

Those interested in developing the art of singing and music and thus praise the Lord through songs and music should join these groups. The required musical instruments should be made available individually, by the group, or with the help of the church. At the informal meeting, the group members pray, study the Word of God and sing songs. With the help of a knowledgeable person, they also develop their skill in singing and playing music. They worship the Lord by singing praise songs. As they develop and practice singing, they can join singing ministry groups and visit homes and communities with their ministry.

Good Shepherd Ministry to the Inactive

In order to search for and revive inactive members and to bring them back into the fold, a "Good Shepherd Ministry" should be started in the church. Like the Good Shepherd, this mostly searches for the lost and brings them back to the church. ${ }^{1}$ The following plan can be implemented:

1. Make an appeal and select twenty people from the congregation to uphold this ministry. These can be men and women who are faithful, attend regularly and are actively involved in the church. They should also have compassion for the lost.

\footnotetext{
'Edward R. Dayton and Donald A. Fraser, Planning Strategies for World Evangelization (Grand Rapids, Michigan: Eerdmans, 1980), 57.
} 
2. Form ten teams of two persons each.

3. The pastor, elders, and Sabbath school officers should prepare a list of names, and addresses of those who have not attended church for more than a month.

4. The team should visit the non attending members at least once a week.

5. In the course of conversation, they should find out about their well being, difficulties, and problems. They should find out what has hindered them from coming to church.

6. The team members should read or study the Bible with them and have prayer with the persons they are visiting.

7. The inactive members of the family should be helped to overcome barriers that they might have, such as family problems, sickness, busy life, or ill-feelings for the pastor or another member.

8. The inactive members should be regularly visited for Bible study, prayer, and fellowship.

9. They should be encouraged to take an active part in church activities, according to their interests and abilities.

10. The active members should invite them for fellowship meals and convey to them Christ's love and deep concern. This should help lead them back to the church. 
Allen, Vaughn. Victory on the Battle Field. New York: Teach Services, 1998.

Arn, Win, and Charles Arn. The Master's Plan for Making Disciples. Pasadena, California: Church Growth, 1989.

Autrey, C. E. Basic Evangelism. Grand Rapids: Zondervan, 1981 .

Bauer, Bruce. Class Outline for MSSN 606, Church Growth in World Mission, Andrews University, Spicer Memorial College Extension, Pune. 1997.

Baumgartner, Erich W. Class Outline for MSSN 735, Strategies for Church Growth, Andrews University, Spicer Memorial College Extension, Pune. 1997.

Bradshaw, Malcolm R. "A Thought." India Church Growth Quarterly 2 (July-September 1980): 104-106.

Burrill, Russell. The Revolutionized Church of the $21^{\text {st }}$ Century. Fallbrook, California: Hart, 1997.

Callahan, Kennon L. Twelve Keys to an Effective Church. New York: Harper and Row, 1983.

Chelliah, Zechariah. "Seven Growth Principles for India." India Church Growth Quarterly 2 (July-September 1980): 97-99.

Cunville, R. R. "Our Task in India." India Church Growth Quarterly 1 (January-March 1979): 5-6.

David, George. "Principles for Indigenous Mission." India Church Growth Quarterly 12 (July-September 1990): 101104 . 
Dayton, Edward R., and Donald A. Fraser. Planning Strategies for World Evangelization. Grand Rapids, Eerdmans, 1980 .

District Census Handbook: Kolhapur. Mumbai: Government Printing and Stationery, Maharashtra state, 1991.

Edge, Findley B. The Greening of the Church. Waco: Word, 1972 .

Elliot, Ralph H. A Church Growth That Counts. Valley Forge, Pennsylvania: Judson, 1982.

Fadnis, Samrat. "Kolhapurchya Audhogic Vishwachi. Safar: Udyamnagar." Muafir, January-March 1994, 17.

Finney, Charles Grandison. What a Revival of Religion Is. London: Morgan and Scott, 1910.

Gibbs, Eddie. I Believe in Church Growth. London: Hodder and Stoughton, 1981.

- "The Power Behind the Principles." In Church Growth: State of the Art, ed. Peter C. Wagner, 190-195. Wheaton, Illinois: Tyndale, 1986.

Hedlund, Roger E. Building the Churches. Madras: Evangelical Literature Service, 1982.

- Evangelization and Church Growth. Madras: McGavran Institute, 1992.

Jilla Samjik Va Arthik Samalochan 1995-1996. Mumbai: Arth Va Sankhiki Sanchalanalay Maharashtra Shasan. 1996.

Johnstone, Patrick. Operation World. Carlisle, U.K: Operation Mobilization, 1993.

Khatavkar, Santosh. Karvir Darshan. Kolhapur: Sukh Dham, 1998 .

Kraus, C. Norman. Missions, Evangelism, and Church Growth. Kitchener, Ontario: Herald, 1980. 
Logan, Robert E. Beyond Church Growth. Grand Rapids: Fleming H. Revell, 1996.

Marathe, Nandkumar. Kolhapur Darshan. Sangli: Gokhale Granth Prakashan, 1998.

Martin, S. O. 15,000 Miles to the Truth. Nashville: Southern Publishing, 1961.

McGavran, Donald A. "A Church in Every People: Plain Talk about a Different Task." India Church Growth Quarterly 3 (July-September 1996): 5-7.

- Understanding Church Growth. Madras: Evangelical Literature Service, 1982 .

McGavran, Donald A., and Win Arn. How to Grow a Church. Ventura, California: Regal, 1985.

McNutt, Francis. Healing. Notre Dame, Indiana: Ave Maria, 1974 .

Miles, Dale. Church Growth: A Mighty River. Nashville: Broadman, 1981 .

Mulik, B. B. "Shiroli Audhogi Vasahatichi Chuddaud." In Rajashri Shabu Mahotsay 1993, ed. R. K. Kunberkar, 94. Kolhapur: Rajashri Shahu Chatrapati Memorial Trust, 1993.

Nelson, Marlin L. Principles of Church Growth. Bangalore: Acts Trust, 1995.

Pimenta, Simon Cardinal. "Revitalization of the Church: Towards the $21^{\text {st }}$ Century." Indian Missiological Review 15 (June 1993): 5-12.

Ponraj, S. Devasagayam. Church Growth Studies in Mission. Lalgarh, Madhupur: Indian Institute of Multi-Cultural Studies, 1988.

Rajashri Shahu Chhatrapati Smarak Bhavan Udqhatan Samarambh. Kolhapur: Rajashri Shahu Chattrapati Memorial Trust, 1981 . 
Reeves, R. Daniel, and Ronald Jenson. Always Advancing: Modern Strategies for Church Growth. San Bernardino, California: Here's Life, 1984.

Ritchie, C. W. A., to F. E. Spiess. July 2, 1949. Office of the Executive Secretary, Maharashtra section of SDA, Mumbai.

Sargunam, Ezra. "Experiments in Applied Strategy." India Church Growth Quarterly 1 (October-December 1979): 56 58 .

Schwarz, Christian A. Natural Church Development. Carol Stream, Illinois: Church Smart, 1996.

Segler, Franklin M. Understanding, Preparing for, and Practicing Christian Worship. Nashville: Broadman and Holman, 1996.

Shenk, Wilbert R., ed. Exploring Church Growth. Grand Rapids: Eerdmans, 1983.

Smith, Paul B. The Church on the Brink. Wheaton, Illinois: Tyndale, 1977.

Storm, Richard B. "Church Growth Principles from the Book of Acts." India Church Growth Quarterly 6 (JanuaryMarch 1985): 71-74.

Topne, Prasad P. "Brief History of the Holy City of Kolhapur." In Tourist Guide in View of Kolhapur. Kolhapur: Scenery Publication, 1997.

Vasantharaj, Albert S. "A Portrait of India: III." Study material prepared for the Global Consultation on World Evangelism, Seoul, Korea, 1995.

Wagner, C. Peter. Leading Your Church to Grow. Ventura, California: Regal, 1984.

- Your Church Can Grow. Ventura, California: Regal, 1976

Warren, Rick. The Purpose Driven Church. Grand Rapids: Zondervan, 1995. 
White, E.G. "A Call to All Our People." The Indiana Reporter, February 25, 1903, n.p.

- Christian Service. Washington, D.C.: General Conference of Seventh-day Adventists, 1974. 
VITA

Personal Background

Name :

Bhupal Ramchandra Chandanshive

Place of Birth:

Karoli (T), Sangali, Maharashtra

Date of Birth:

June 1, 1956

Married:

August 21, 1983

Educational Background

$1966-1970$

Primary School, Jeevan Shiksan

Vidya Mandir, Kumbhoj, Hatkalangle, Kolhapur, Maharashtra

$1971-1974$

S.D.A. Mission School, Lasalgaon, Nasik, Maharashtra

$1975-1979$

B.A in Religion, Spicer Memorial College, Pune, Maharashtra

$1988-1990$

M.A in History, University of Pune, Pune, Maharashtra

M.A. in Religion, Andrews University, Spicer College Extension

$1996-2000$

D.Min., Andrews University, Spicer College Extension 
Professional Experience

$1979-1980$

1981

1982

1983

1984

1985

$1990-1995$

$1995-1999$

$1999-$
Associate Pastor, Aundh Marathi S.D.A. Church, Pune

Associate Pastor, SDA Church, Shivaji Park, Kolhapur, Maharashtra

Pastor, SDA Church, Prabhu Chanya Ichalkaranji, Maharashtra

Pastor, SDA Church, Mangalwar Peth, Miraj, Maharashtra

Pastor, SDA Church, Shrirampur, Ahmednagar, Maharashtra

Pastor, SDA Church, Satta Colony, Ahmednagar, Maharashtra

Pastor, Aundh Marathi Church, Pune, Maharashtra

Department Director, Maharashtra Section of SDA, Mumbai

Executive Secretary, Maharashtra Section of SDA, Mumbai 